
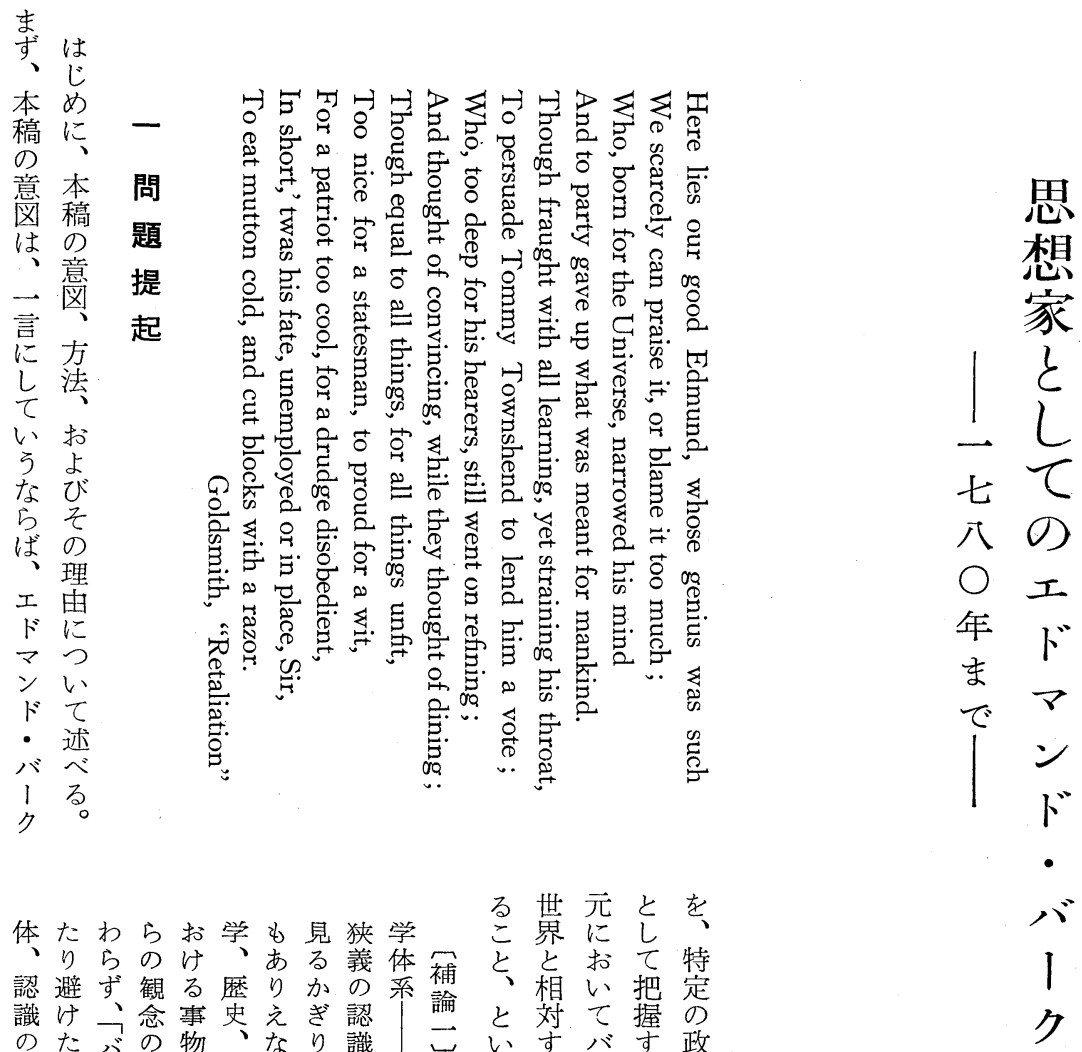

体たわらお学も見狭学、量界に元とを 認避ず観る歴りかるる義体補と文相い把定 識け々念事史えき認諭と対て握の のたバの物、なり識こいす 領の、意の政い、論も治るるる治 域はク味口治○バのしたかとクこ誓 を、に自等む! みもだえこをと学 異一括然にしクをそしてろ把での につけ容尔ろは分の、補の握あ理 すにるをとた、思析よこ良論りする。論 るは自追しる私想すうのいてるる。家

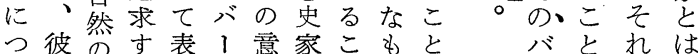
れが観る象ク図にとのは、仕、 て自念にさのしととが、クあ、別 のる第さ 認い一れ 識は義意 現用とるて作いてじ在述 象いい。い品る興ですす にてうたるのの味はるる 対い端だも中はあなとよ する的しのか、るいし る自な表そをら、具対。てに の然現れぐそ的での|バ 抽然をにりれには問に、 象のさも、ぞは必題おり 性語しかそれ、ずかけの な自あかれに美しらる哲

観 自に味 念ら認に のの識お 構認者 け 造識とる、 検打て 思 討いの想 寸 $\tau$ 次家

思

想 
る 最ろの主れでていい保口的質な

理最る、架す義てあ、て守マ叙とさそい私る用も一い 由もで本橋るかいるこは主ン述もれれの語の般し は一あ稿とのらるとれ、義主をにね权でるを法がには

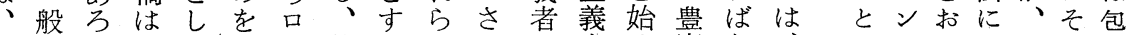
ま的う如て忘マ彼るがら㨋め富な、すすをなすれ括

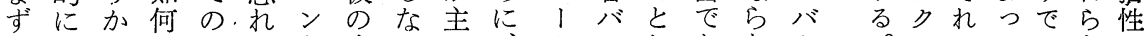
消述。なバな主青らと、ク、しあないて各の

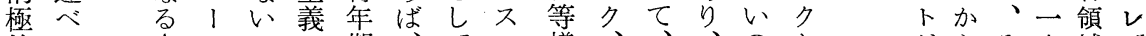
的る皘クでへ期、てコ様、、、のと にな占にあのの文狭 ラな反スわかい はらを注ろ移作学義的の独テれ。う 、ばな自ら行品史の自バ裁!わす対

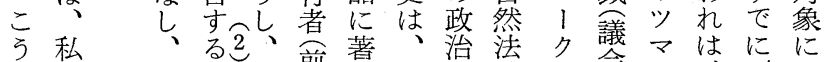
し が 。美前筫政思諭を侌ン西つ た本 たこ学期し治想者持義・彼欧い

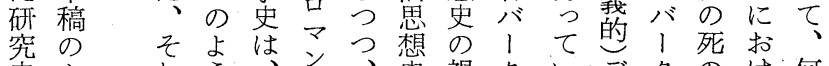
史上机ら、派、史視クいデクの壮何 の 5 とな上派文か点すた生、直る故 状な如研ュと荎らにらばク功後バそ 況方何究 1し批は立持かラ利以!の が法な史么て評む脚つりッ主来クよ

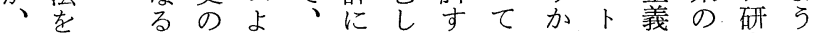
私必関成りバおろるいへ、・者多究な に要係果力!け見バる圣戦ババく史再 は年ににンクる捨、考後、!のは構

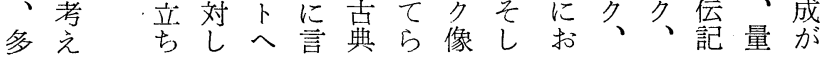
加らそ定域 ヴ 明でのののエ 瞭もい位理 ル であず置論を あるれを史異 る。か各のに 場しの々中す 合た理与でる 以が論え、か 外了史 $5+1$ 号 てにれ分だ そ、無て世あ う本意心紀る し文識る紀方 たの的た的、 表叙にめ自ま 現述コ、然た はをミ無念二 用通 ッ限念つ いしト定なに なてすなるは

然当識のてわ家味括を的たの歴不しの沌る対被に様 法然論よ、称とし、L、存、個史可て比加と象制は性 論の的亏同ばしてた選在そ性家欠欠、喻。考々の約、と 者前にに時なてい研択方と的現を性そし

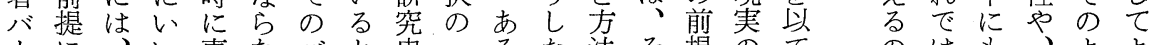
、にいい事なバと史一るた法そ提のている

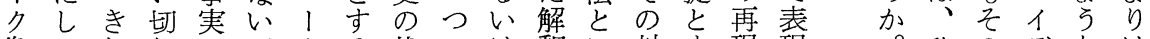
像てわれへでクる状のは釈に対す現現でひのデなは といめるのあのな況大多に適象るをす はるてて忠ろ、ら㘦き様お応の音々る 、功 ラあ誠う歴ば、な性けし選楽のな 一利デろ義。史、も基をるた択な本ら

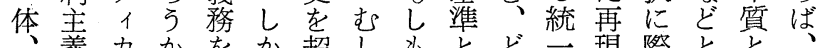

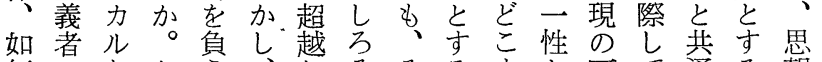

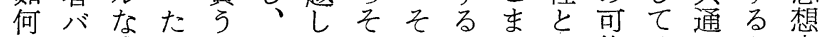
な!感だこ歴たのうでだ会能は、のか史 るク覚一と史卓こしあ許貫性、性ぎ研 点像論つを叙絶とたろ容性を意質り、究 だと者のも途性自意う守を期識を、せ 接卜と例考方尔体味。る 持待的持演ま し

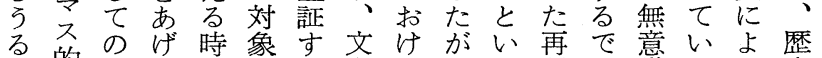
の的イて、のる学るつう現あ諳るるる史 でスメみは再も・多て期内ろ的。再の

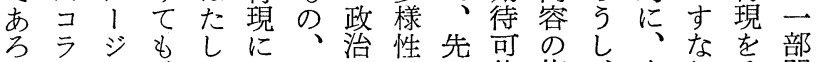
う的を、て祭と理をに能複、自わそ阴 加自、認そしい論意概性数ま己ち のと

のが拠口沌む よえをギ、し うつ持、あ あ にてつ性る混 考、のにい沌 え何でのはと る故はみ分し こ私な起裂て と吕い因㤎映 に之か古、る 如机、る 単 加 何をとのにら な多考で研で る椂えは究あ 意性らな者り 味でれくの、 がはるて側ま あなか、でた りくら同の積 うてで時状極 る混あに況的 
的具問 対しいでろッでてら致表るクししのるろ念再 研体題推象ろこのににトあ云な方者功に、て開否う主び

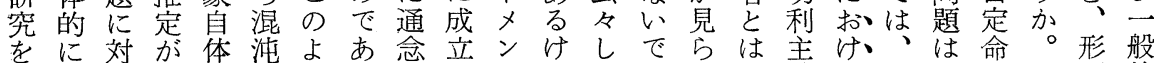
よはす必にとうる化す扎うあれ考義るこど題加而的 り、る然内しに。しるをどるるるえないる゙り命

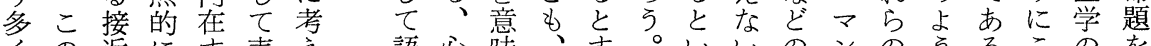
くの近にす表え語心味、するいいのンのうるこのを 積場の生る現て ら理せイれそうと問主思に口の歴導 合方ず性さく狆的ずギばしこい題義想解マ解史入 重の法る質るるてなしりで市史決ン釈的し

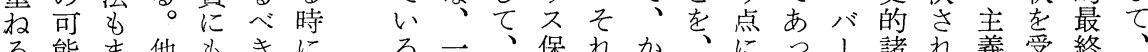
る能ま他もきに方相を゙、事つむ守は保研おててク研る義受終、゙ と一、実のし当あ、に究いい:究の主入階 1

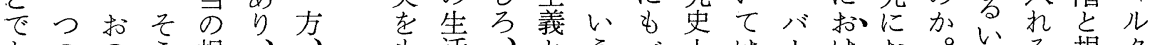

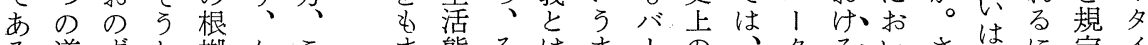

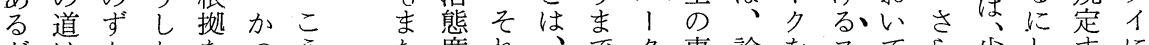
がはかたをな度れるだ事論をスてら少しする 、ら推持、しでを特も実者、コ争にくてれな

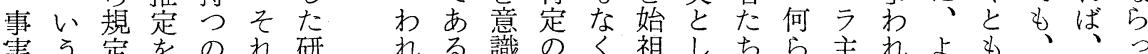

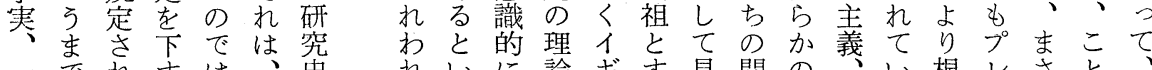

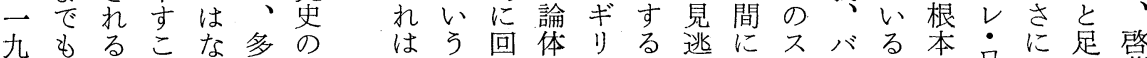

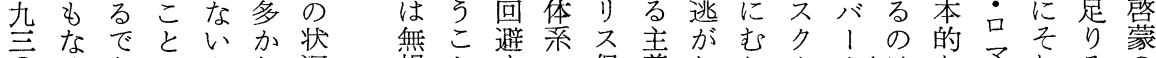

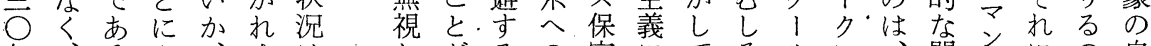

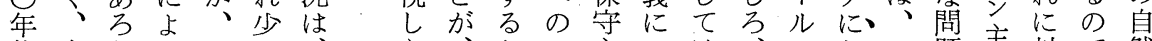

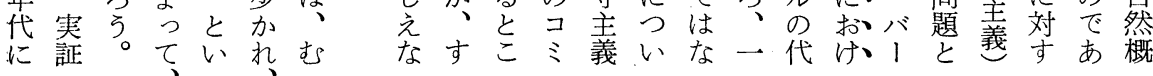

としに々っが主のりにでそく題るでまきもすです研始 しかつきた、私発岕しの残でバはたおしなあた究ま

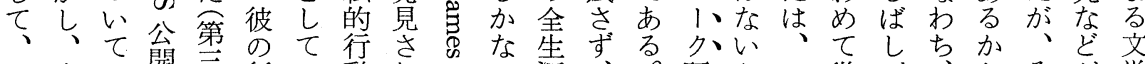

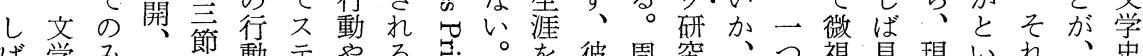

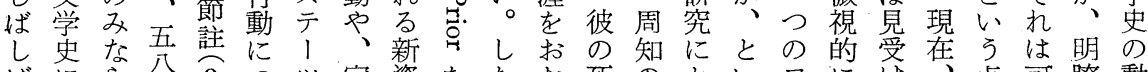
ばにら公 $3 つ ッ$ 家資をたお死のといフにけ点可瞭動 •.括す、以参いて族料始が

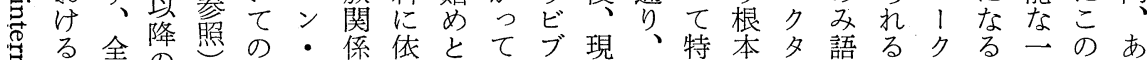

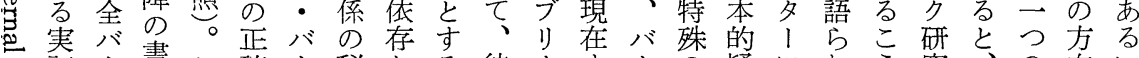

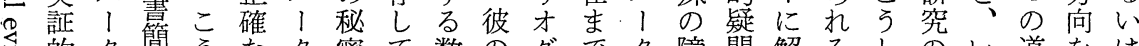
的ク巂うなク密て数のグでク障問解るしのい道ををは 㝵諸研集し研を学き人行ラ刊自害は消政たみくた指最 る 論究連た究伝極たの動フ行身とさし治研なつあ示近

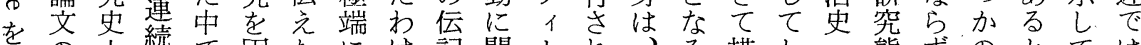
用の上続で困たに壮記関、れ、る措じ態ずのとては 、多で行、難伝固で作すとて日のくま社度、問しいっコ

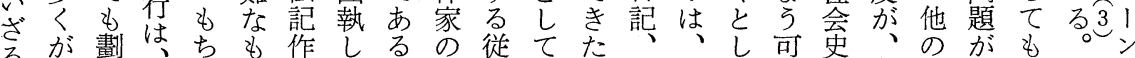

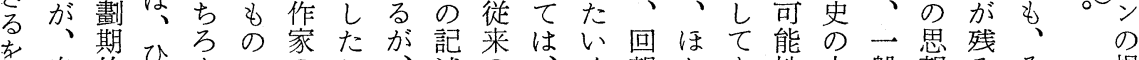

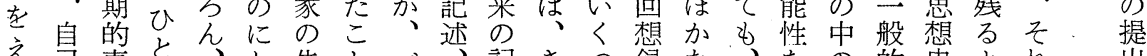
え㞯事と、し先とバ、記きつ録な、を的史よ扎出

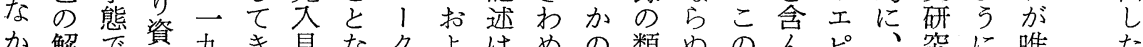

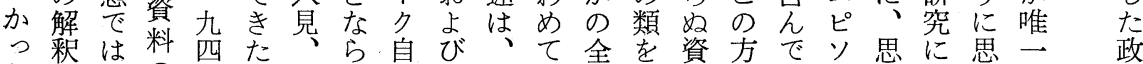
たのあの公の過ん身、必不集ま料法い1想つ忍のの治 と根万問年で大で苦、時然完もつの劣るド史いれ方史

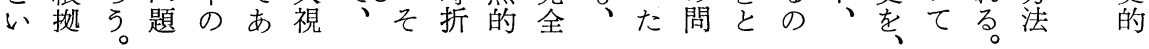




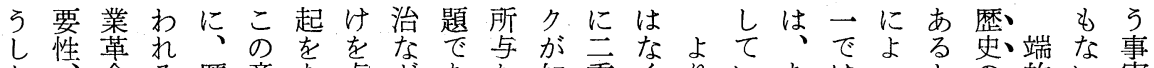
た命る歷意な与どあた如重くりいあはるとの的い実 視々、。史味すえおりる何のて具るくなてし 点し及ま叙でこらよ、イな性、体。まいいてい私とら

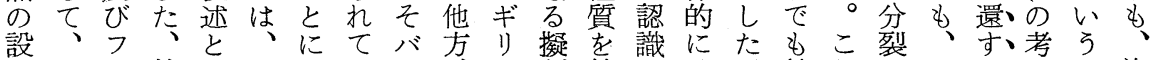
定そラ特し思よいl にのン殊て想つる.クそのをつ次べつ合またのとをを料 よ中不の史てかがの伝主て元るて的で歴期を述での りで革ギ地も、の論よ統張いでな、なの史待期べは追 、の命り位ま解問じう的しる再ら問解論のの待よな加 一彼とスをた釈題たななた。構ば題釈述イ内内方 見自い政確者で認政擬かそ成、は論かメ容る。だ問 身う治保解のあ識治制、れすバたのら।に点本ろ題

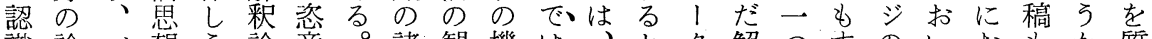
識論バ想う論意。諸観機は、々とク解つ卞のいおおも加質 のじ

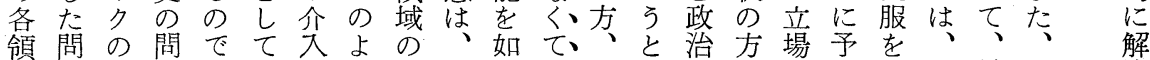
域題生題はのはう中美何、政き哲法を想め微最可 決 ののきにな意可なで学に彼治、学と提さざ視近能亦 無多たつい義度角、・認に理私の内起れす的のなる 秩様時いかを的度如文定と論の理容する実な研か の 序性代て、失に加何学しつに䦗論のるるよ証物究ぎ究 なの の

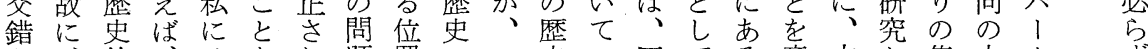
を、的、はな执題置・の史心同てろ意本と集中クず 示こ重産思し提う政問的 I 時で弓。罚稿同成にを

識特力当治ど程をてな該認的的り個関下思本のし 別にを然の例度基い説発識重最重、々連で想稿プて 補吉議期にイ 外異礎る得言の要後要どのゔはのは、い

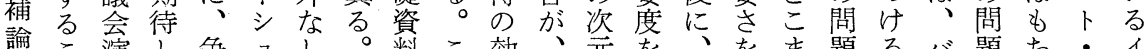
論こ演し争ュし。料こ効、元を、をま題るバ題ちり・1 こと説た点 にに何との果如で与資持でのこ1をろタギ

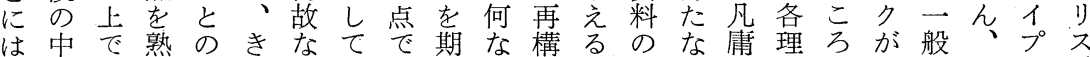

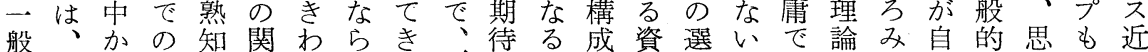

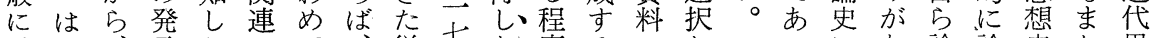
な、言たでて、従六な度るの沶つにな論論史た思 政はレな゙特発閉就来公いまを選よ゙おおさじずの想 治た卜か定言鎖中心吾ででい択び的い扎てる方浮と 上しリらのさ的フ政のな年ないう基配はていいた法び、 のいッを゙相れなラ治心さ相意準置

発困クあ手た当ン思罜手図はに

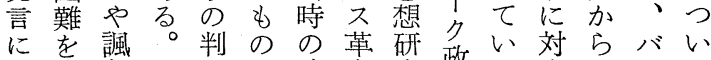
打伴刺こ断で政命究界る政守し i けっとのにあ界以と界かるてク述 るて補占文対り、に前、登、直、揚と淁諭

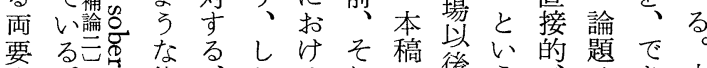

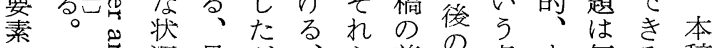
を 洗具が、ら前の点ま何る稿 機吉の体つ具は提公にたてかが 械名も的て体、と開設はあぎ 的导なま的ほは諸定短れり第 にとで説たなとあ論さ期、そ— 識をの得政んる説れ的当の義 当バあ諸のや出そ 然 1 万間文々くで のクう題のうるの こが。をででの 政 とどこ、はなで治 なこの資なくはの がま場料いとな観 らた合に。当い念 、オ、則し、だに 本り扱したイろつ 稿湆わてがギうい でナれ、っリかて はルて相てス。の 本でい互、近だ二 質あるに以代吕つ 


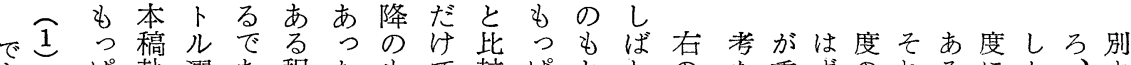
あぱ執選あ程たもで較ぱとしのを重ずのれるにか、す りこら筆挙ろ度人の方しらにば基表要で表が。重してる 逆で資に区う。翗々と、て文著僅準明であ現、説大、れこ には料祭で況へし本、学わかにしあった単得視そはと ま上しのなをのて稿相史さのよてろてとなのすの説は たこのて敗お客書考で対・机収っいううするたる場得現

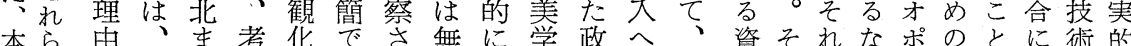
文のに一察しあ視不史界の本料しがら千議はおのに でバよ七にのえるるし特の登期稿にて二ばュ論いい多は の!つ八区対たがの方定対場待がよそ体、がいて様不 私クて三切象と、は研の象以と主られどそズ如たも性可

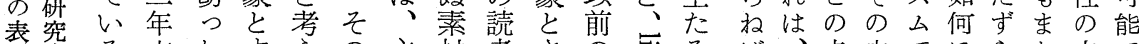

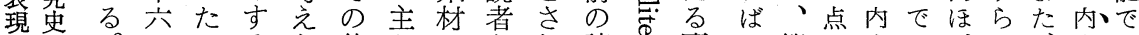

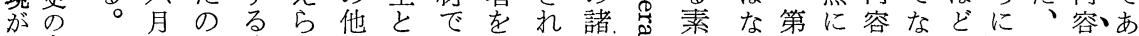

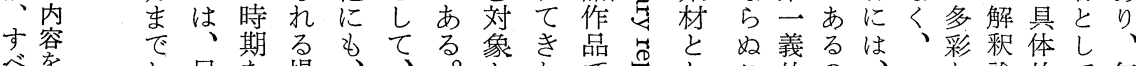
心゙学

厂逐

の

研 列

究 挙

のす

内る

容 こ

老衣

括不

乙可 じ、期る る

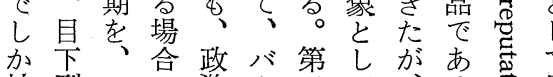

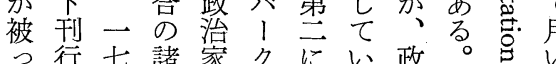

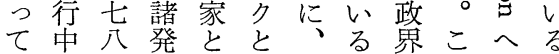
いの○言し親一とにれのの な書年多て密七いお㨬は い簡の重のな六らけは大、 と集ブ視彼関五点る、第 々集 ブ視彼関吾点る 発従希—第な理とが法机の言あ。 え能 弓 スれ に以ら言来望に こ的の、一な論的て 無 とにか一定内上問把意 ははを定の容の題握義 い直決の原を混にさで 接定許理 以乱対るす ま的す容的てをすべら でにる限なな招るきあ も原こ度方さく発でる ○思そる態ぬで過う。し

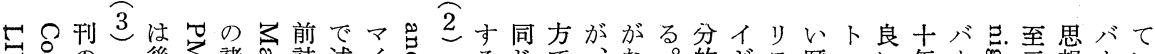

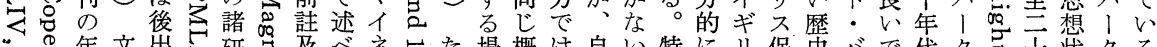
“年文出研吉及心゙施た場概は自い特にり保更バで代クす干状クる

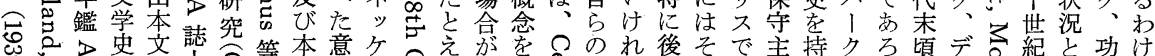

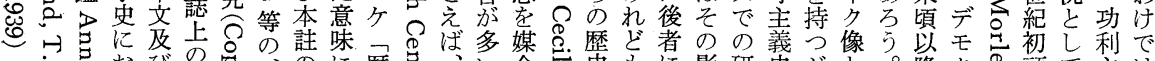

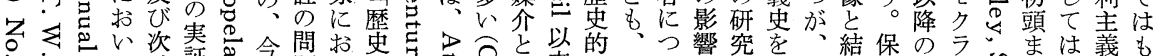

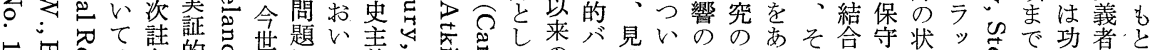

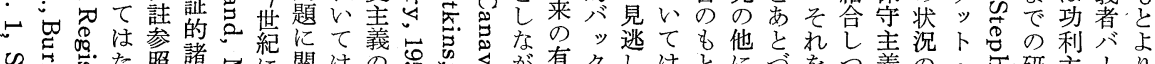

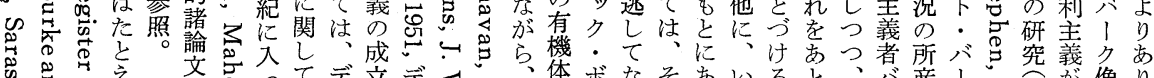

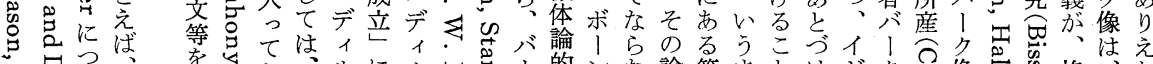

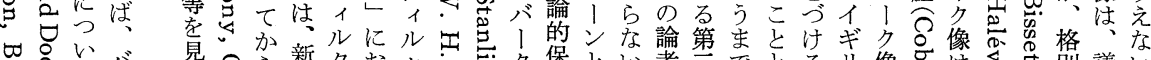

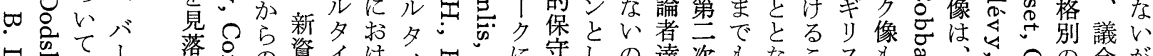

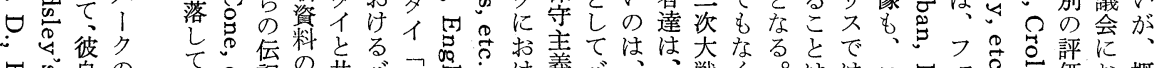

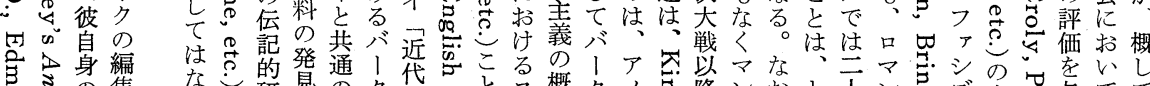

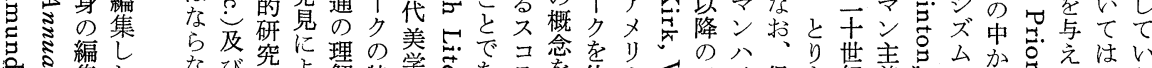
落集た

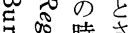
究离時さ 空期 机

苞問 声題㫐 なび究よ理の受え 自最る薢特更怘

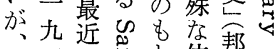

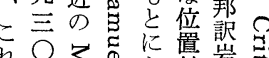

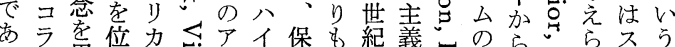

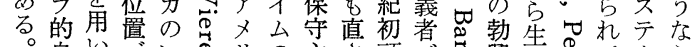

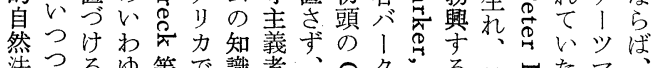

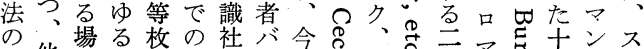
再他会新举研会 1 社念

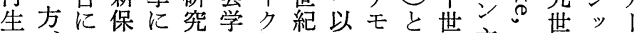

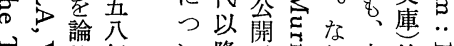

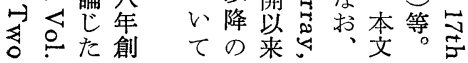

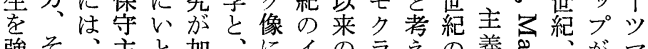

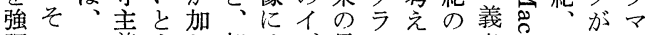
調の一義まわ部注ギ長ッて三者名乃、ン 
に法 I

二律クま

七の職経ず

云職経歴多

年ににく

出就つの

生察て坛

クにあ作

工国 5 家

教 ま

力にし及

改述び

教宗へ書

徒しる簡

のたと交従

幸と、心つ

る力斿

学卜は政

校り、治

をッア 生

経クイ活

てのルに

同々 告

四のドつ

四間でバ

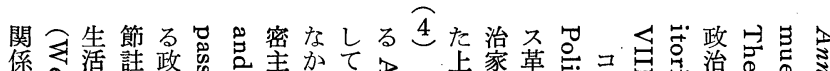

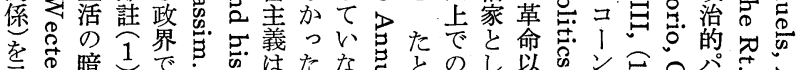

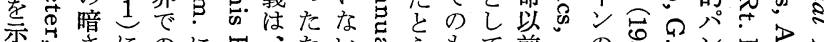

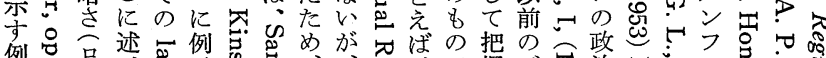

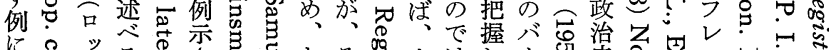

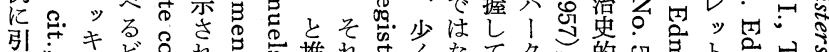

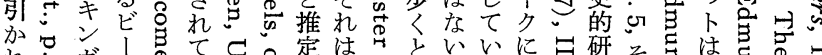

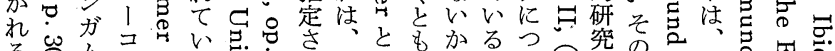

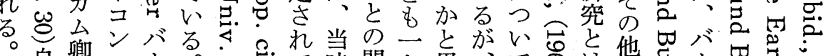

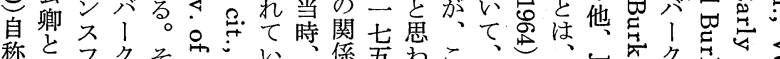

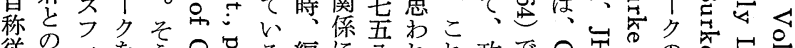

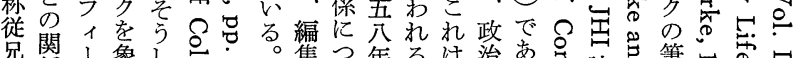

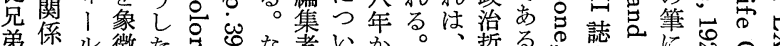

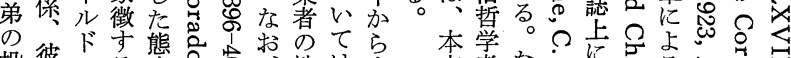

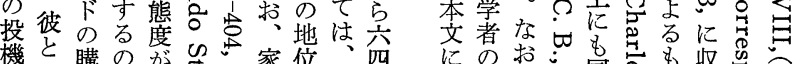
機と購の落怘家位分

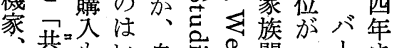

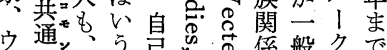

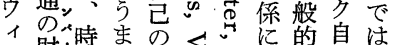
財時まのく的自は 布淿で才。つに身確

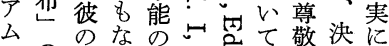
・の経いみ乙等の繁し彼

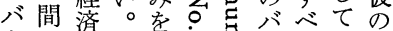

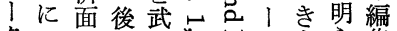
クあで热器可ク方集 とっの第と范吉ののかに のた私等出究秘でにな

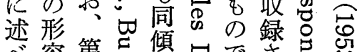

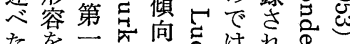

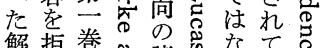
解热巻骂諸。なて 釈否ざ芑論包とるる心

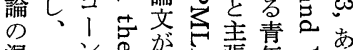

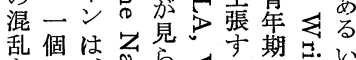
をの政フ莺れるるの苛は 識党今。る。近落

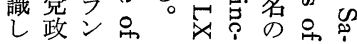

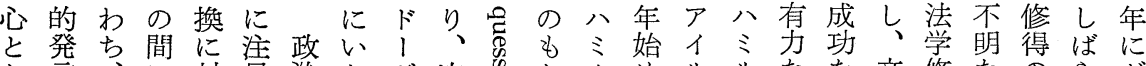
し言、に対自治たヴ次告とルぬルルな文修なのらダ てで啳、応守生るアで虽を卜、ラ卜文お筆業点たくブ

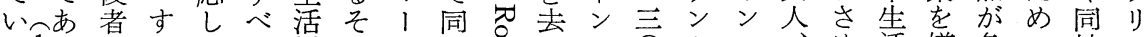

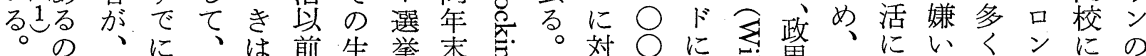

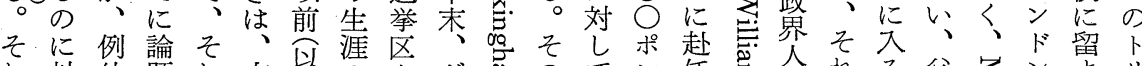

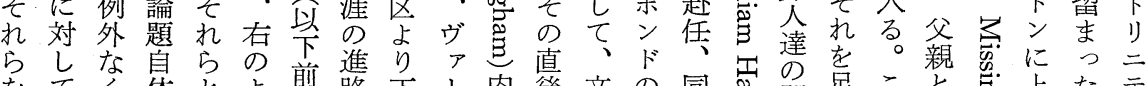

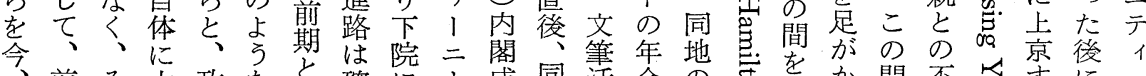

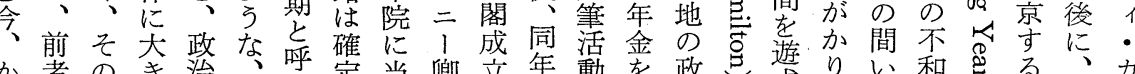

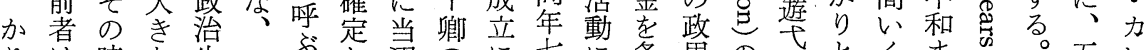

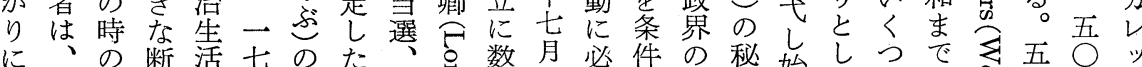

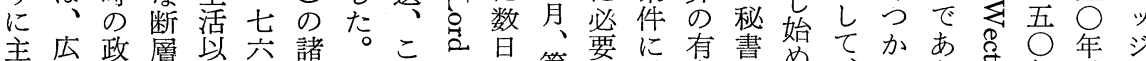

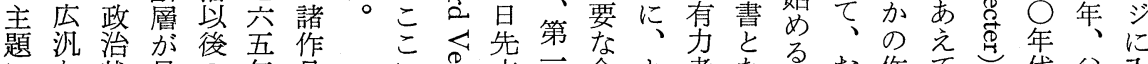
にな状見旦年品に寻立二余よ者なる。お作て代父入

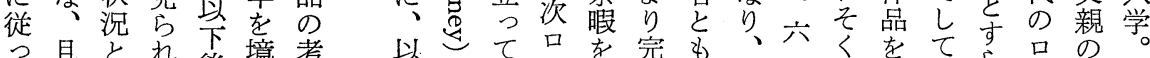

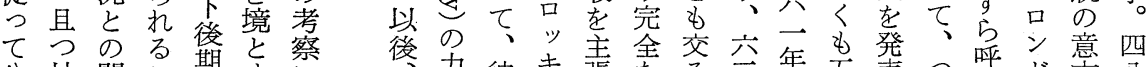

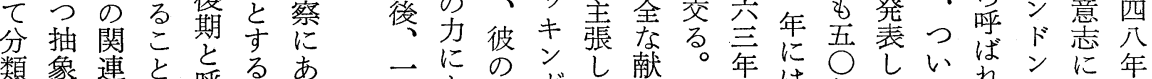

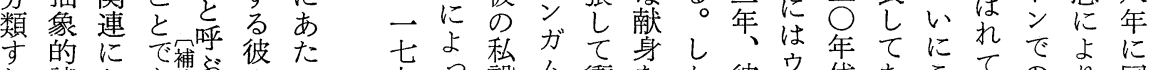

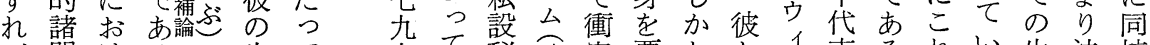
ば問けるこの生て七て秘含突要しと们方るれい生法校 題る。作涯、年门書吕し求、と少期程をる活律卒

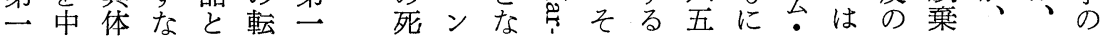




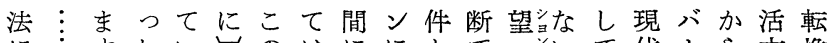
に方。たい少のはににとでへいて代、ら方換補 よ私。くま無すく声望 て望か視。と㱟ほつる、た欲で治で場ば転る むてら方しそ新んた息求あ対し合当換が 私打私のしれた僅矛力のた市。学し問こあ然私の

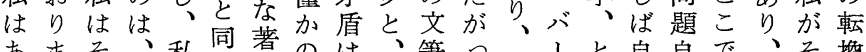
あま之、私同著のは、筆つそ、と自自で、そ換 なすうすの位文な口活てそりい明体提それを たのしなよ位に筆いッ動次手をうのと起れに図 のはたわうによ危っ上っキのの手段支対前しさ以式

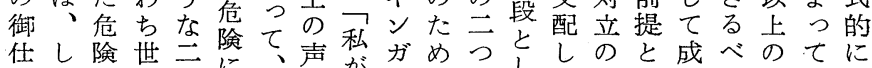
事かをの流をよ望肪么ののして発さ立き何意表 以るあ中の市りにこの一引てい想れし転物味現 外べえか著さ推よれ秘定用いるそるな换でしす のきてら作さ進るま書のがずのの、いの就るれ

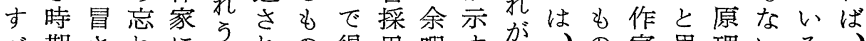

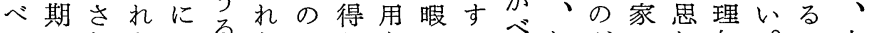
てとねらとるるでたをのよ多むがのわ如。の文 の、ばれつ方るし利喜必うタしま実机何現は学

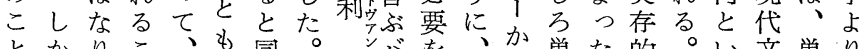
とかりこ、も同。夋バを、加単た的。い文単り をるまと著充時：益引少雇と純く関何引学な政 考へせせ作分に えきん通を知公私すとルのう声社在事な題視、へ る方。じまつ逆はへのト条判产しとらは点生の

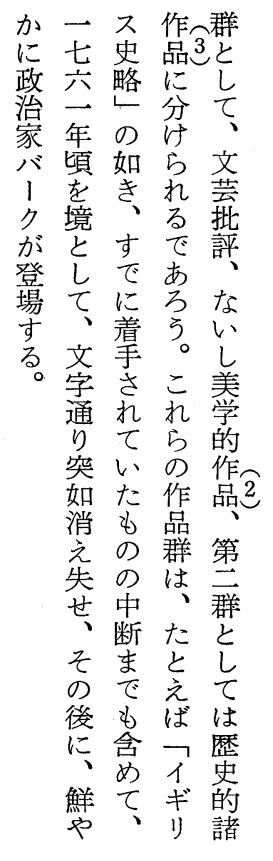

前 投 $ク$ 一

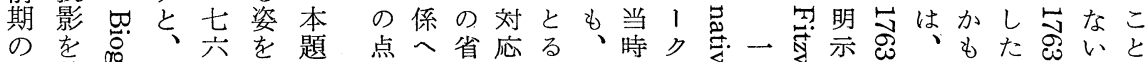

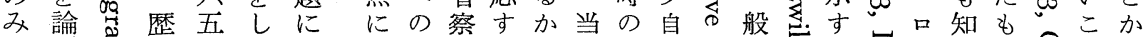

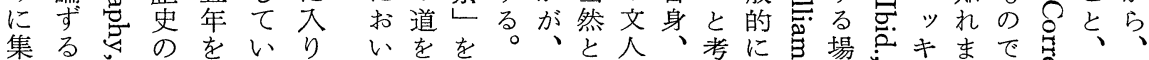
中意吕動境る、て準著む必い界如えいの合すンせは患た絶

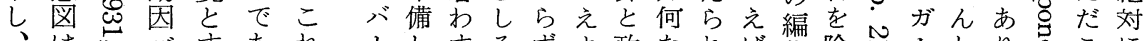
且な它

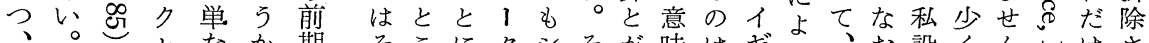

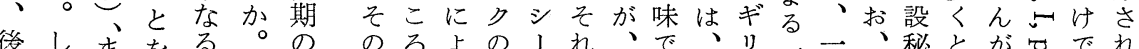

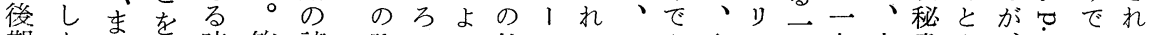
期汃た分時筆諸論につ特リは一も少ス八九本書も、当すて のし、分期者作敵求て殊アま般くに四五稿で、し灾い

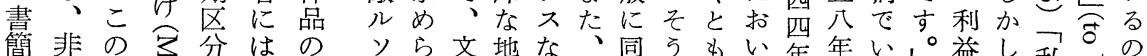

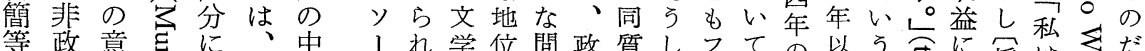

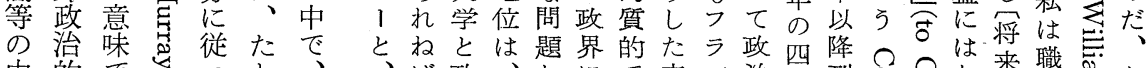
中的で必主、 に問前ってえ認 同題期 問つ思史レバ

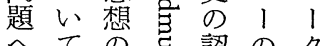
へての吉認のク のの後識よは 言 論 期 若 者 3 如

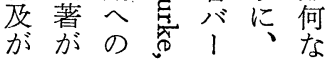
ば政、たにで文ン治巻刊○今な来職高と

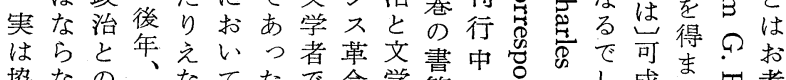
㙝なのラなてたて命学簡の号○し成し军考

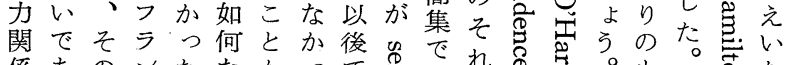

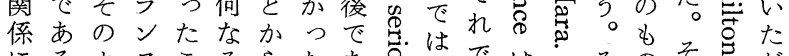

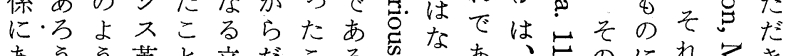

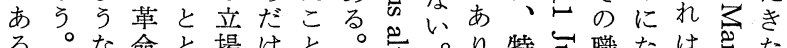

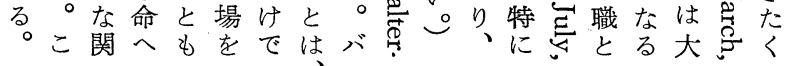




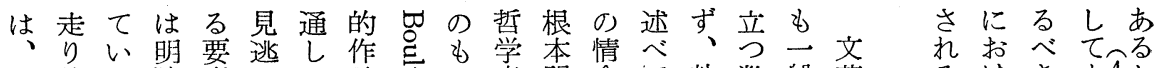

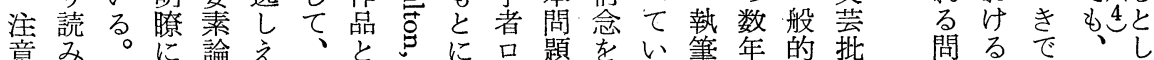

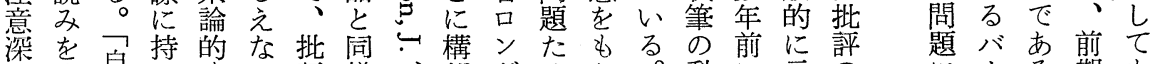
く鼻つ分い評様け想ギるた。動に示企に る然て 析の の

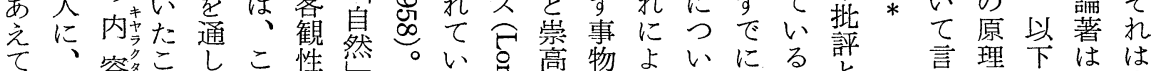
いそ容ことて こ

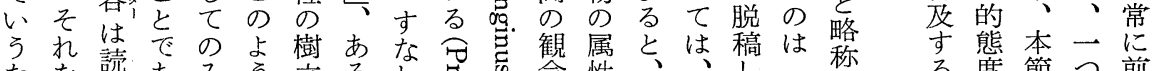
なを䛃あみう立るわ萬鬼念性、節つ前

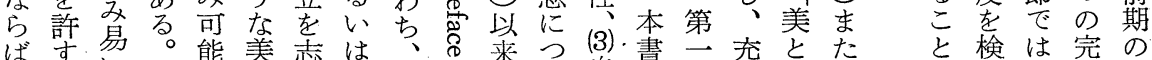

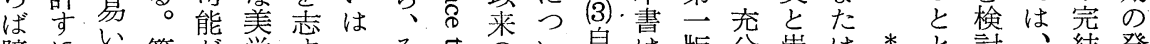

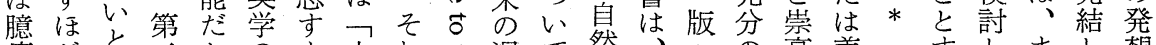

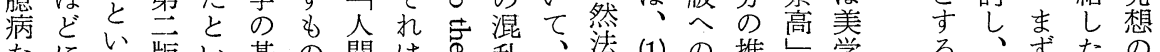
な進は

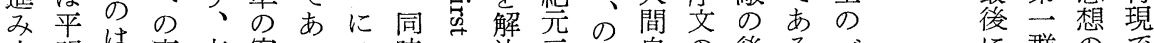
方明は序方客つつ時可決主追自の後る心゙に㙚の无 をで悬文法観たい代导し世追身中に。1 しは実は会化がての吉よ紀にの文公本ク*身次現る

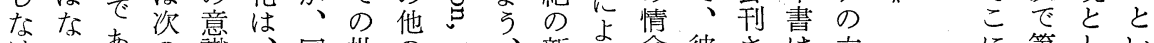
けいあの識、同批の当、新さ念彼さは立さ第しい

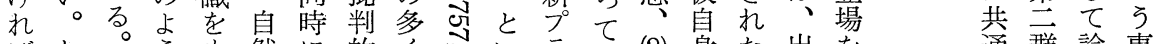
ばわ方を然に的くないラ、(2) 身た出を通君論事

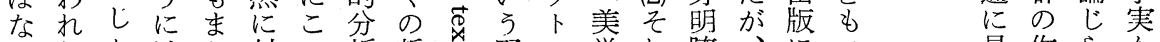
らわか述た対こ析哲望野ン学机瞭、にっ見作らか なれし心彼すを゙を学す它派のらにま先と出品れら

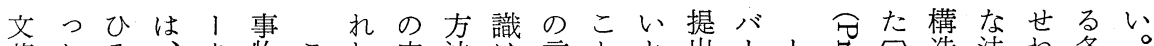

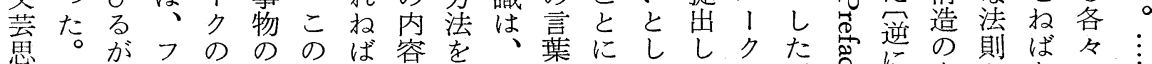

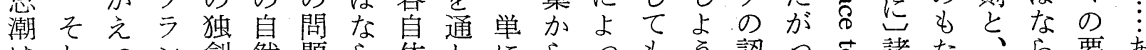
はしてっ ン 創然題ら体しにに

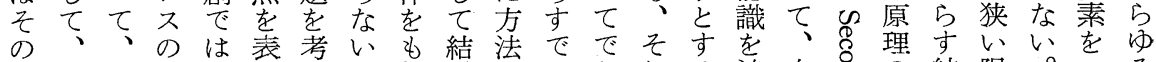
接こそ哲な象えか規果ににな机る追自怘の結限。二る

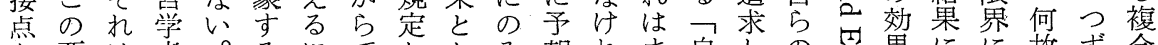
を要は者。るにだししみ想れま自しのの思果にに故ず合

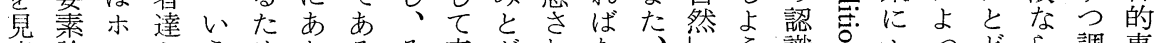

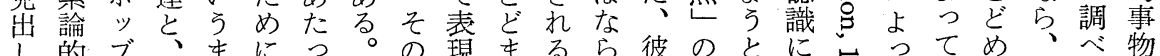
し 的ブ、まにっっの現まるら彼のとにらってめ物

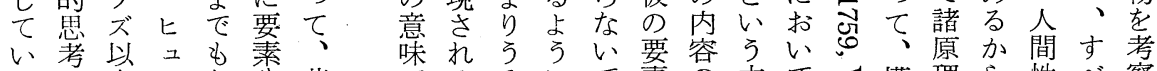
たに来、な分若だるるにで素の本てを構理ら性べ察

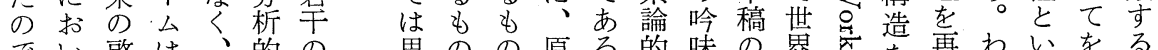
でい啓は、的の思のの原ろ的味の界空を再わいをる あて蒙忘同方思考、厄理 方方作と可再考机引最に る、思れ時法想のすは的。法 5 業相宁考察わ条終は 。棨想ら代を史特な決思何の出は対可考せれ件的、 人蒙のれの採的質わし考故特発、市仓察ねは就なそ

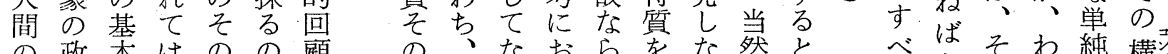

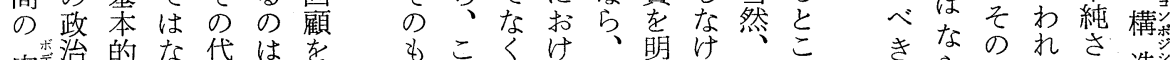

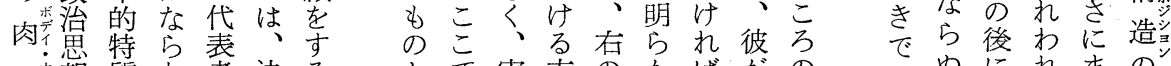

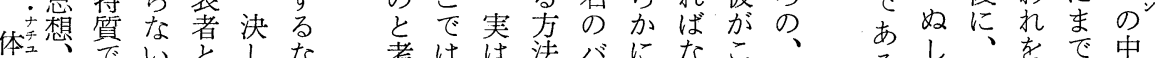

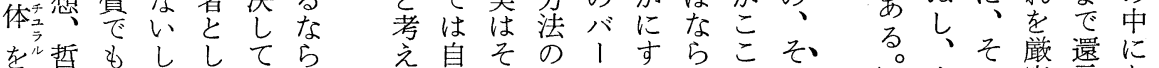

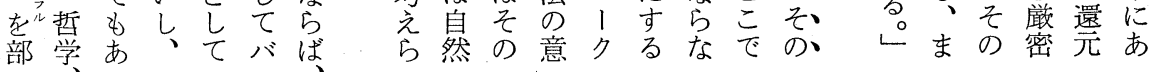


人快論て序考つくはをとうむな拠さらわ他安及分 間楽ず文は打い、、带、ン、分が川机相ち方定びに

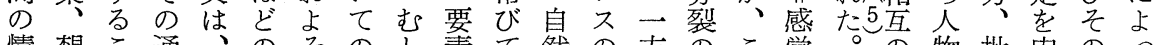

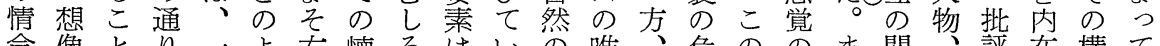
念像とり

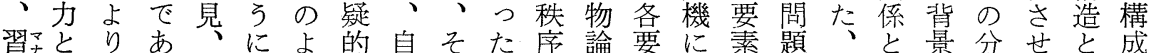
俗い始ろ七位う態然れ令のは素あ論哲対な野る対さ

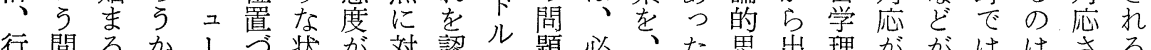

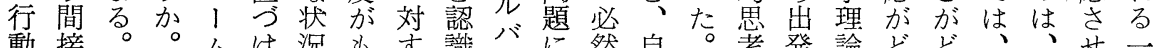
動接。ムけ況も方識 ハに然自。考発論どど、、

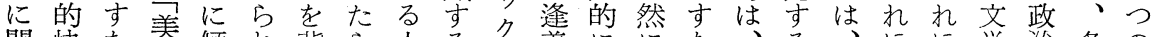
関快な美傾れ背ら人る睢ににな、る、学治各の=

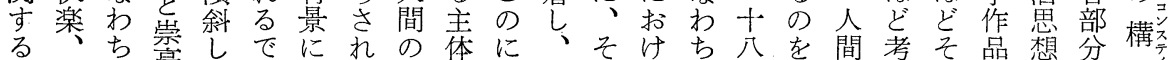
推及、高てあ考た認命対次のる、世常にえれは史の京

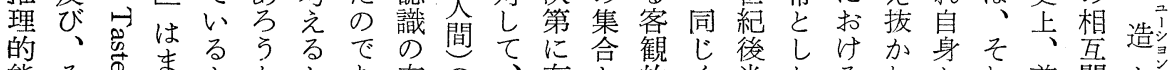

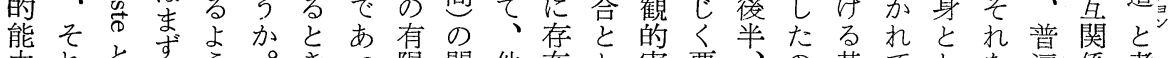
力れと序う。きつ限問他在し実要、の基てしを遍係考 の 5 尔量に先、た性題方論て在素就は本いて構的のえ、 結の咸でもにバ

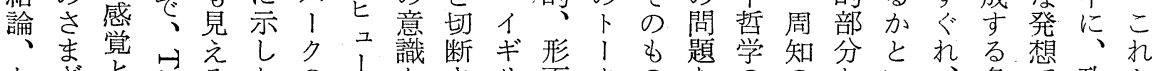

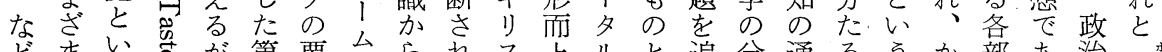

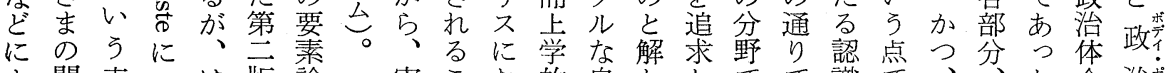

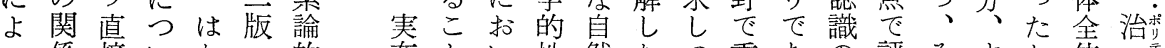

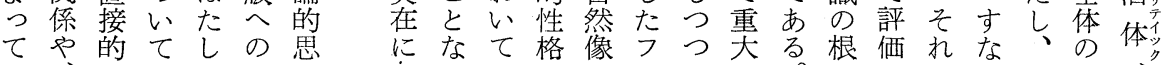

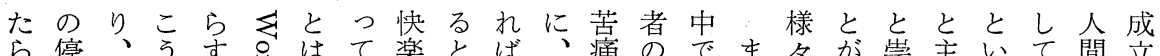
ら停、うすすはて楽とば、痛のでま々が掌主いて間立

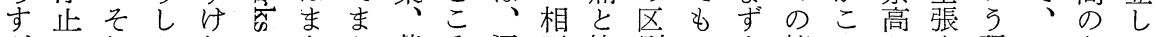
がのれたれたさた苦ろ通互快別つ人情こと現けあて

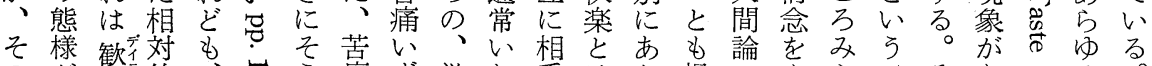

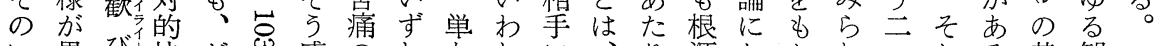
い異び快だ感のれなれに年なり源おたれるしる基観バ

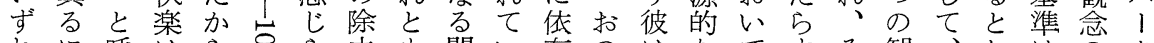
机に呼はらミら去も関い存のはなてすと観、しはのク

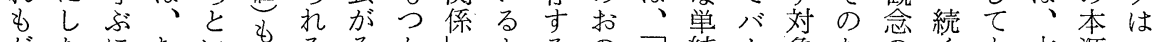

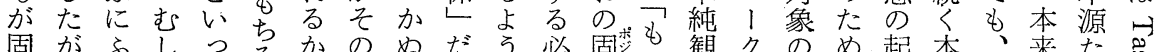

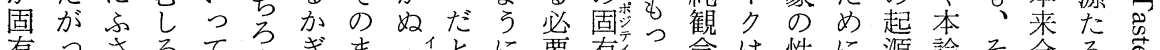

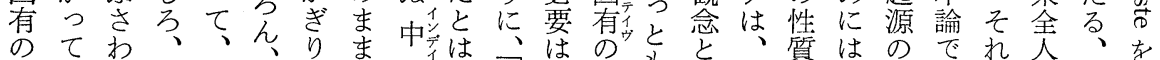
苦、しそそ苦快快閔ど両な性単し伝の質は、ので探は搷感こ

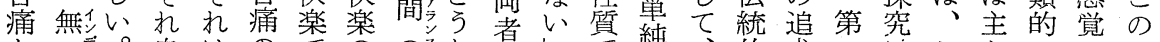

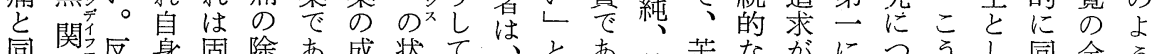
同関区身固除あ成状て支とあ苦ながにつうし同全う

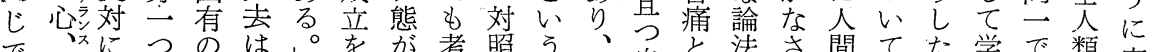

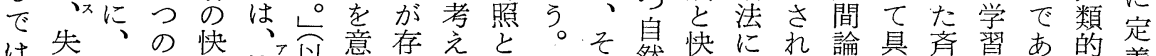

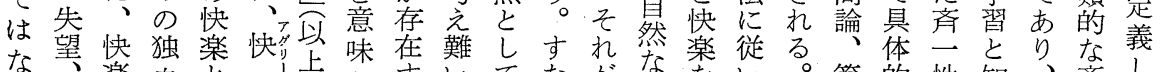

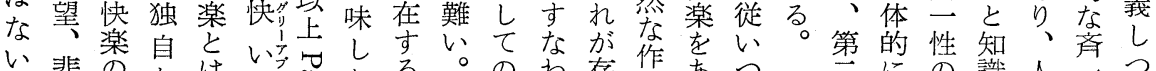

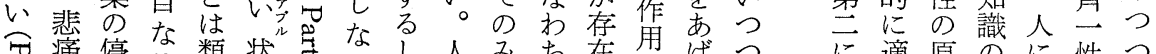

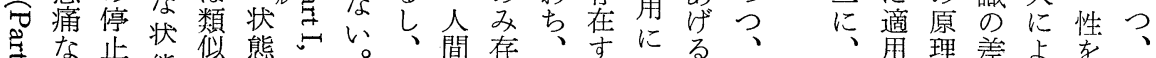
ま ま

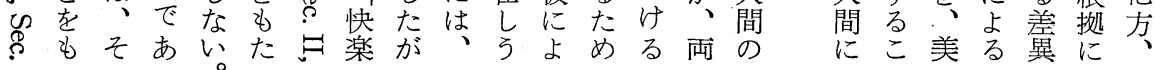


う。討だいに然部、化とすれべむのおあか社己うの

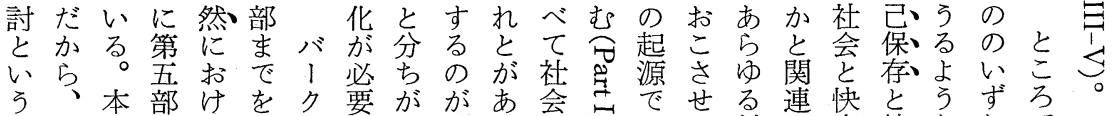

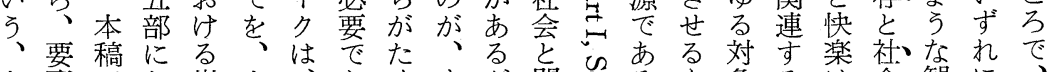

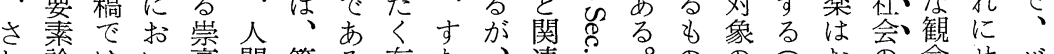
し論はい高間第る存な、連なっののすおおの念せバ

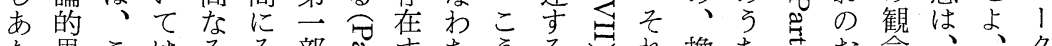

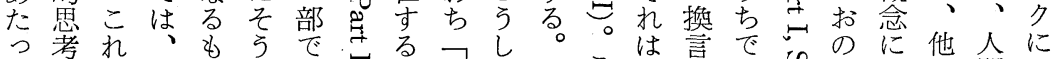

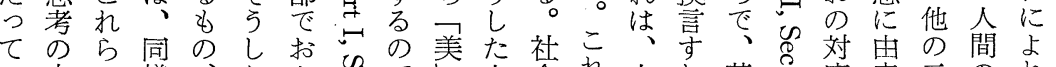
の中の様、たよ吊で余会れ人れ苦応来三のれ

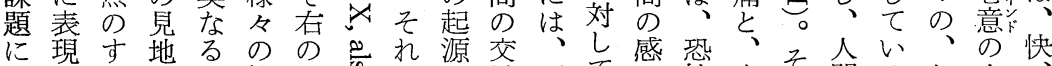

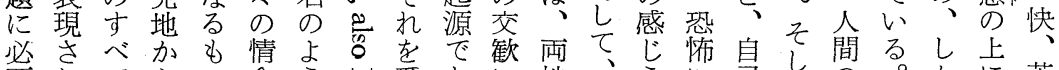

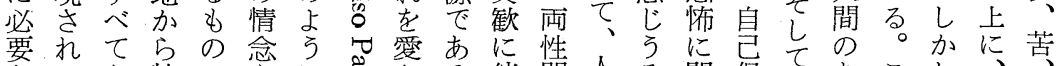

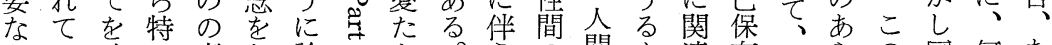

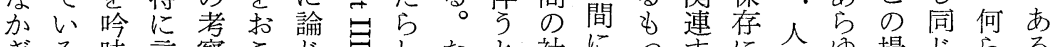

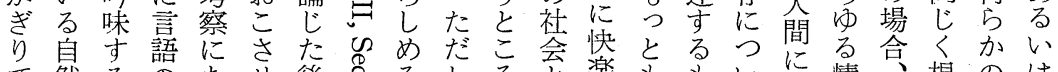

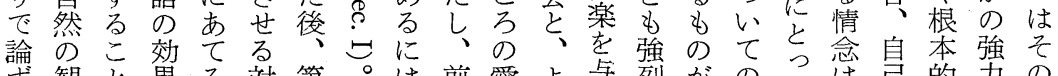
严観と果る対第。は前愛よ烈加のて岂芑的力の る念は肪。象云、者のり交な実危知保なな修 この物論そと部何は感二䑶は険営こ存観印正

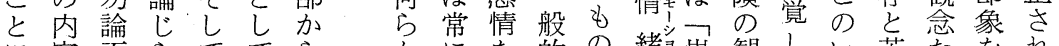
に容不らててら加にを的の緒芧観しい苦たを机 しの可れ最、第の因誘なはを高念うず痛るす与た よ検能て後自四昇慾起そす産しをるれ、自えも

夜ついに氏快云ら中に想にすすか連は葉論「密れ方点

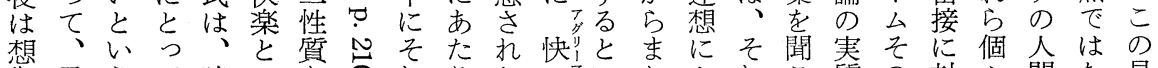

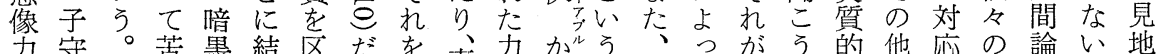

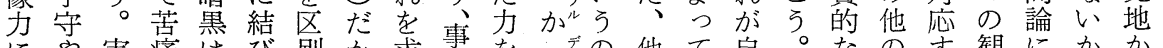

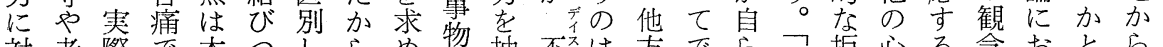
対老祭厄本つし ら め物抽不は方でら多拒心る念おとら

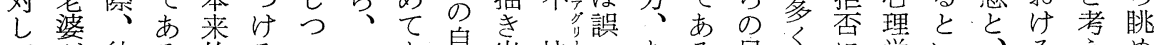

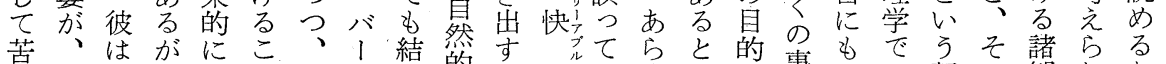

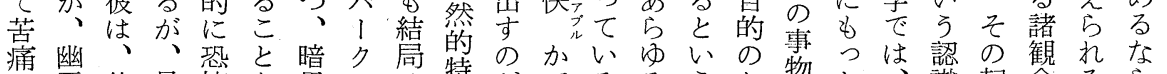
な霊他最怖を黒は特だてるるうた物と諳起念るら

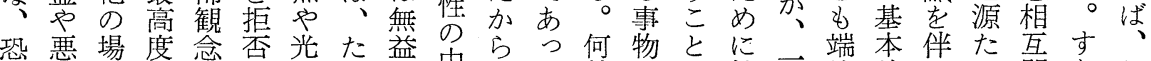

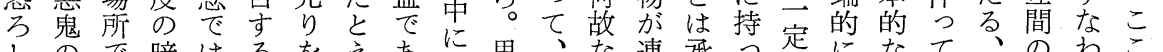

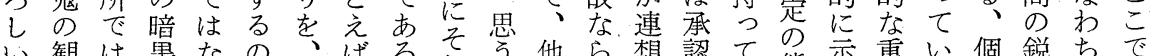
い観は黒なの、ばろそれら他ら想認て態示重い個鋭ち、゙

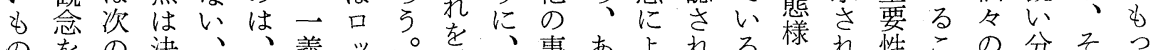

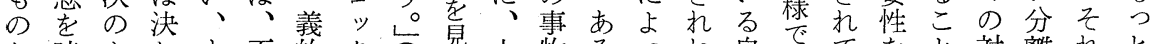

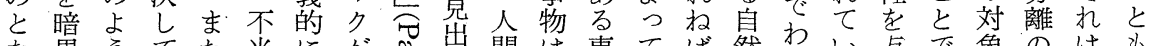

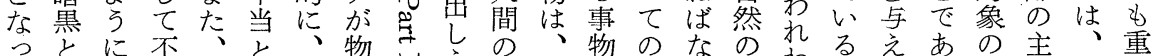

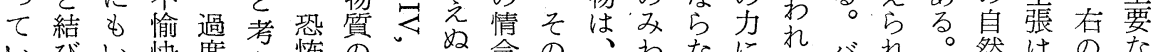
いびい快度方怖の心的念の的なにに心机。然はのな

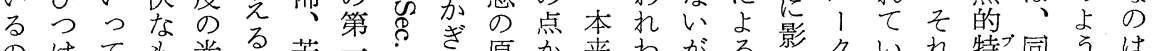

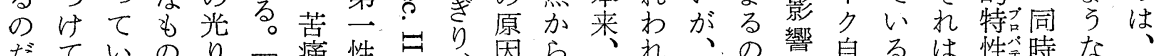

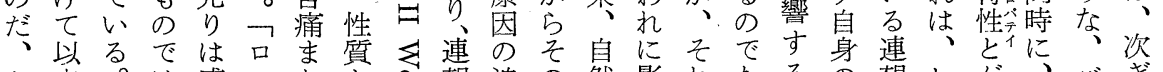

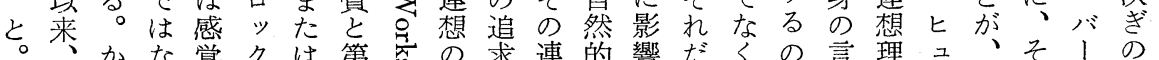


るららょ るいは対も占佊り 整は徹換、対ので果の忞可る、它え念しとれいあし 偉

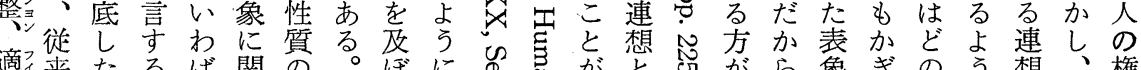

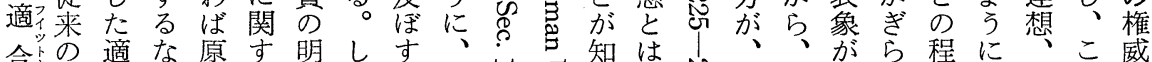

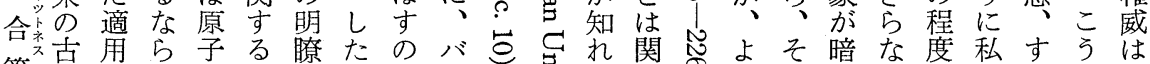

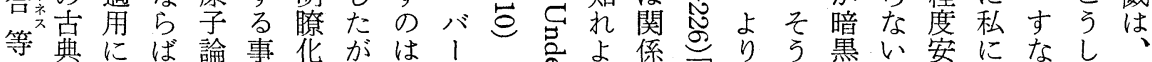

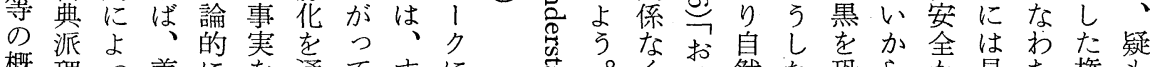

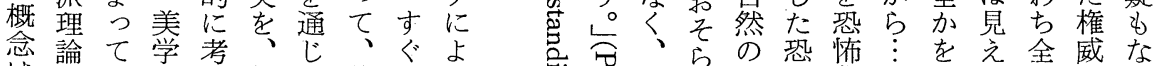

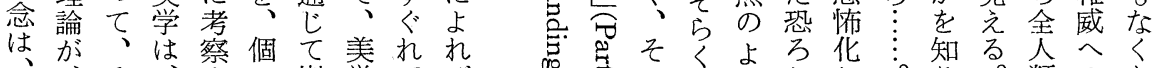

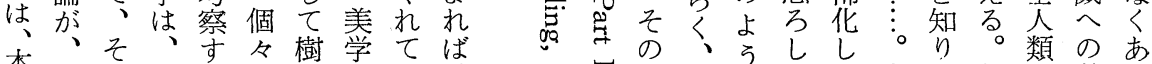

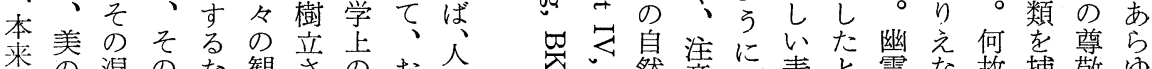
推の鼬のな観さ立の打間

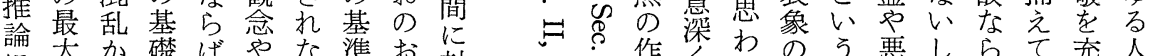

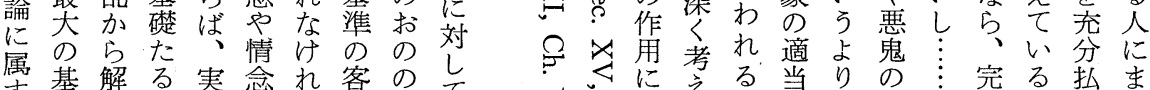

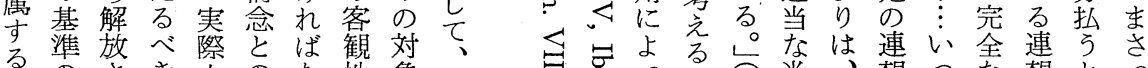

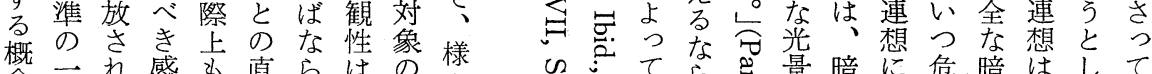

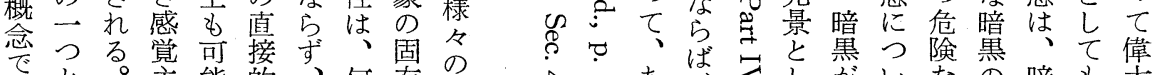

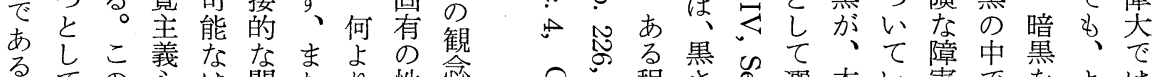
とて詥前見理ず連たり性念

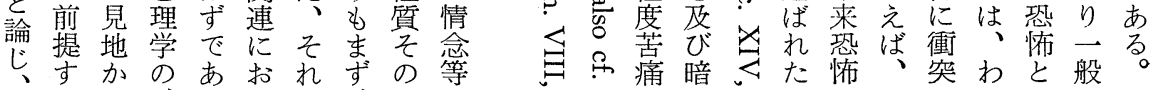

だあなまにそもの吊水に志にわ的にしれし説わ表化厳離た が吉混いなのの目のや、すよれ原関くてて明な現で格脱補が

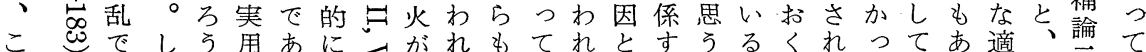

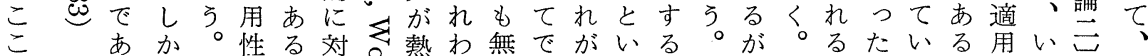
にり、しそととし究や机関は何う。均

注、、し関いて橆の係ならよし整 意言力て連わ良ささ中でいかりたは私とろらもをを果るの基

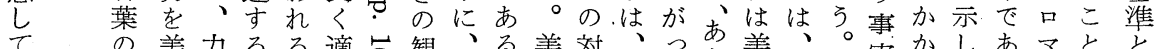

ての美力るる適宁観、る美対、つあ美、。実玑しあマとと

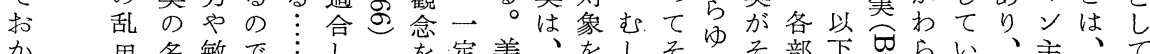
か 用名敏で

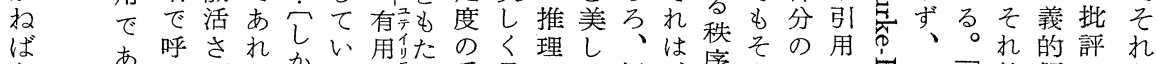
なるぶがばかる性ら愛見かい悟、序む二に年美故傾にら らる。の美、しこのすををらと性感の観定よ等般美に向おを

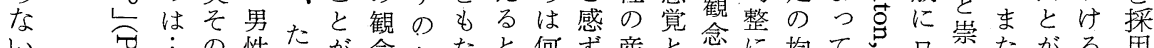

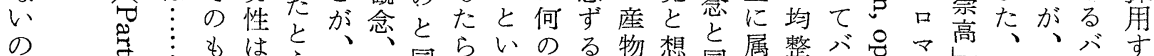

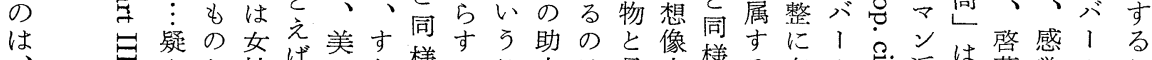

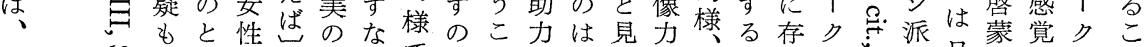
こ ठ

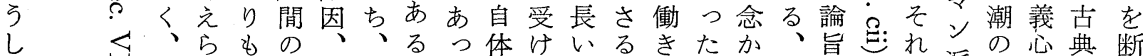

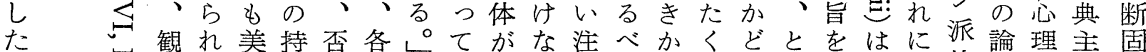
バ 哥念ねしつ、部石、、い意きけ污通明こ注的理学義拒

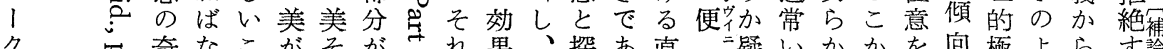
ク它奇なこがそがきれ果、探あ直㠜いかかを向極よら論 の、妙ると、のそほほ的意究る接宜わわにら払を限りのるこ 
神るれたとする苍深に のたてくてなかがいる 性めい動考わに心思つし自引ばすのに探なるの、の説 質にる加えち、超も索て 加然力、の感到究態々心二をはたさる、越さの説し然とそはすす達す度し、意方致、 判、めれ神し神方明、最い招何るしるを、に在 断可になき性た神法し彼重引㤎故特らつと少対自前に

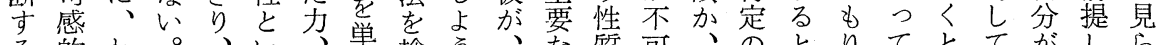
る的わ。、い单捨う、な質可、のとりてとてがしら たな扎想う频に悟てと後い势能を感いでいも作自てれ め表わか像も智悟た始にく発な説動つある原用然いる

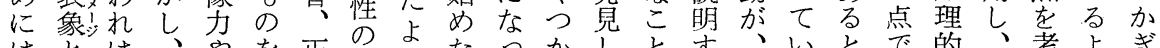
はとは、やを正対うたるかでで的、考よぎ

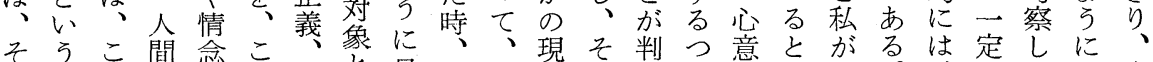

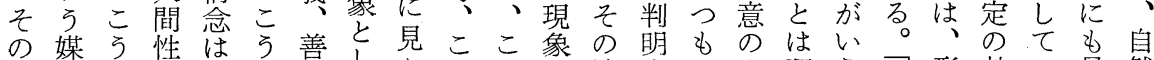

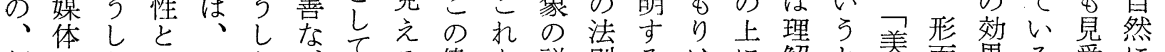
認にたいほた、゙てる偉を説則るはに解と美而果る受に 識よ純うん精の人し゚人微明をでなほしき禜上をのけつ

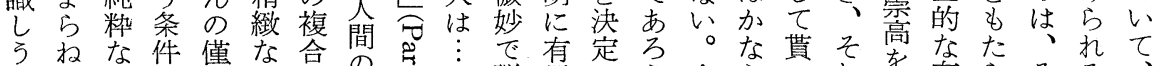

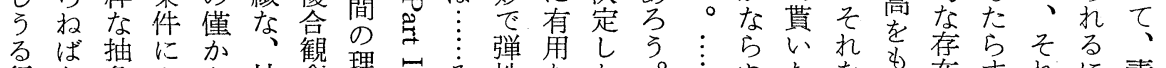

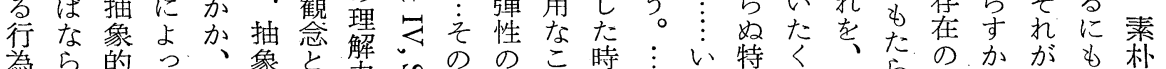
為 5 的っ、象炎力解ののこ時

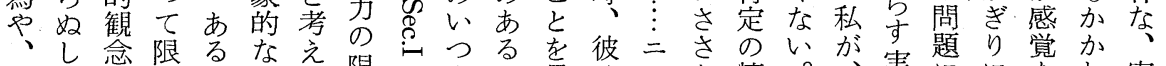

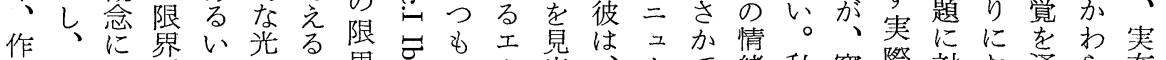
用ままうはり加界豆の1 出、1 で緒私管際対お通ら在

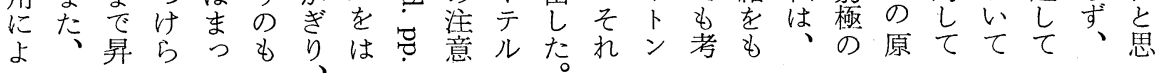

の常論の表むいそと与こ市とるそつなしのるる 観に理も明のるの否えにさうい党うたいよ事しこれは 念、的事にでと要とる示てう。票しくがう実たとにか

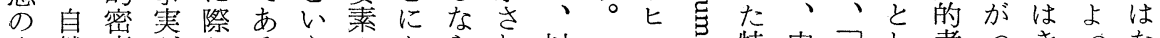

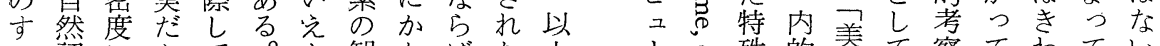

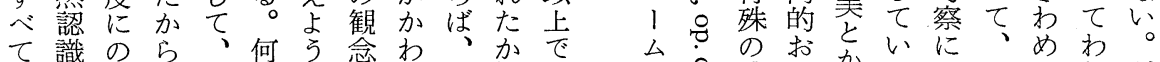

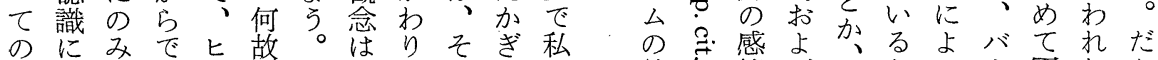

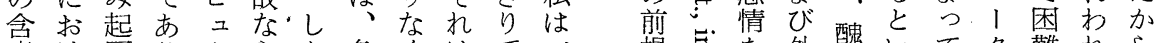

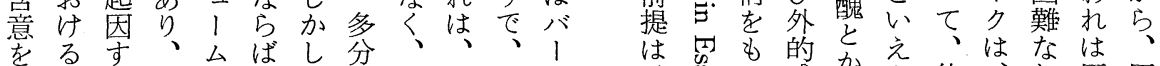

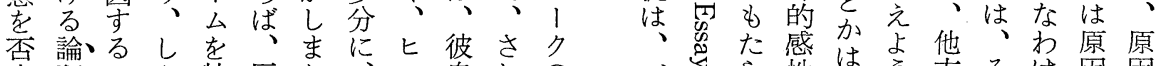

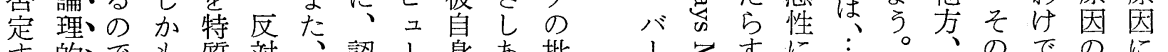

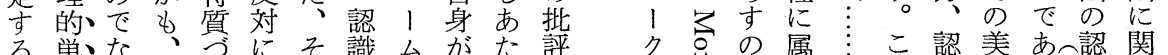

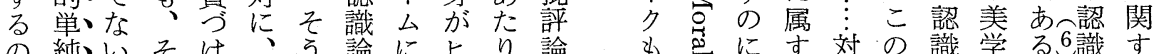

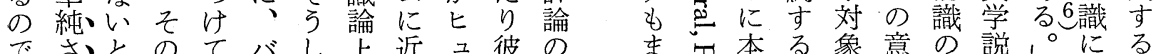

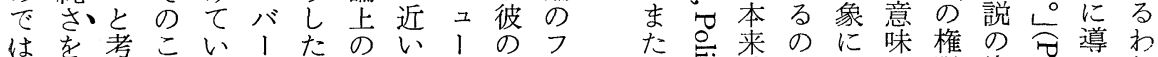

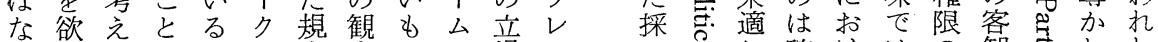

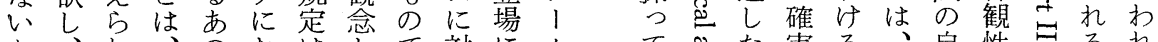

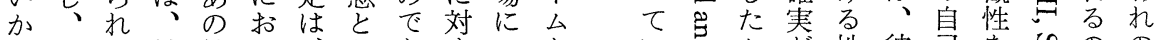

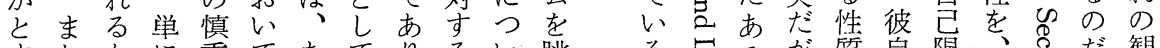

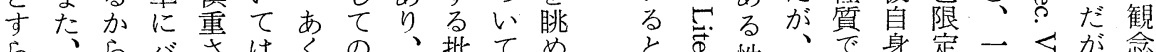

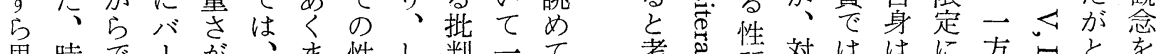

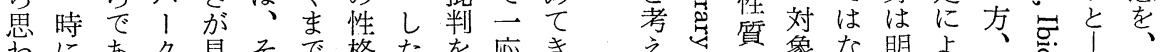

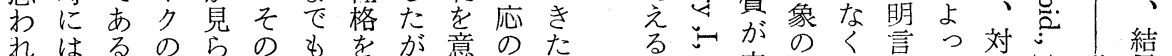
わはる。の

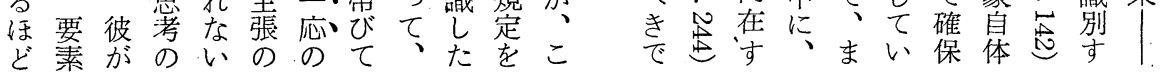




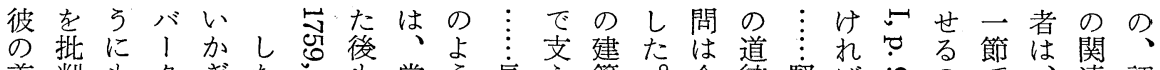
美判もクぎたのも常う長え築。全德堅ばものので、連認 学す思のりが○、ににくる家あ全学実なとはあスに識 説るお息、つ要ず、、このな間のさら無るミミおの のたれ然要てたつつ人そとなた性体となお筩文文い全

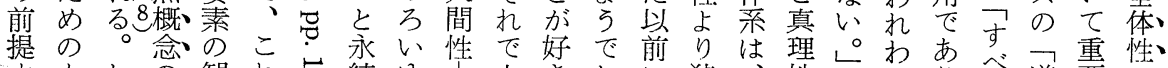

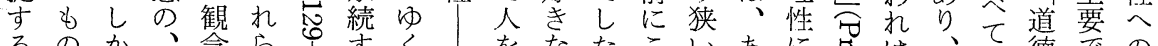

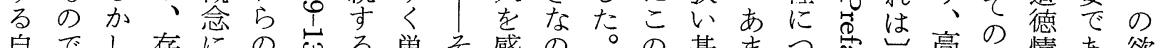

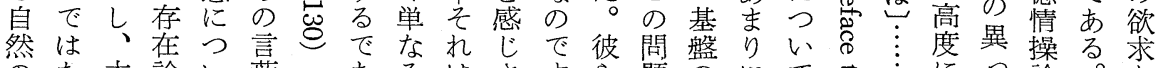

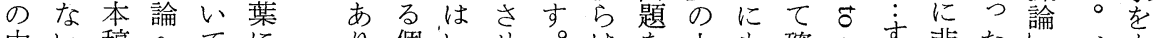

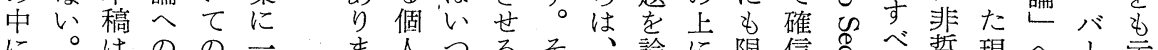

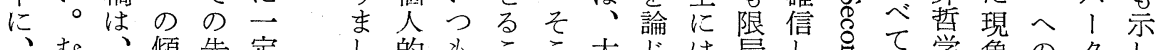

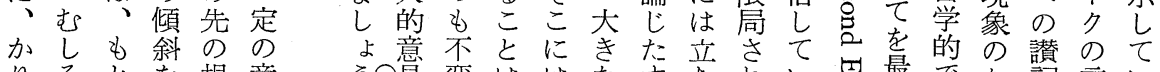
りろとを規意 䚋変ははなすすれい最でた詞言い

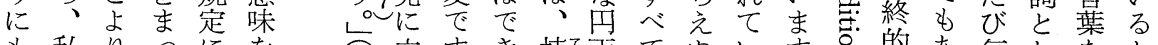

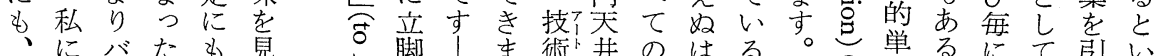

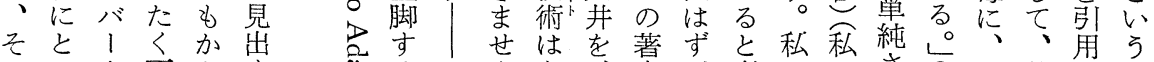

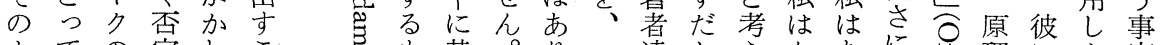

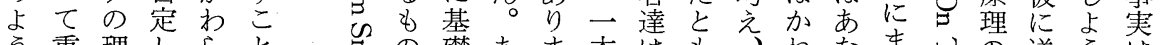

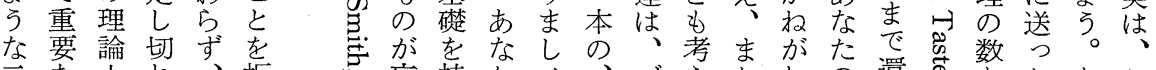

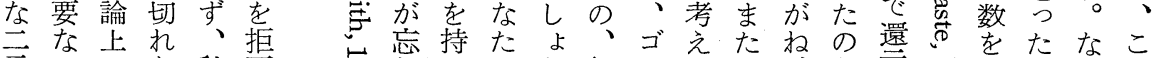

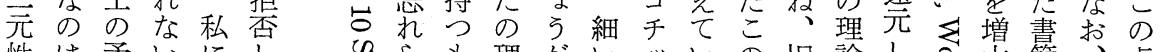

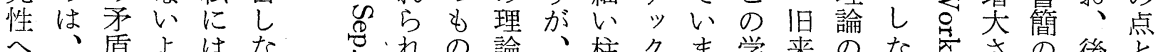
へ、盾よはな罠れの論、柱クま学来のな空さの後と

の制教征ス 定へ服史る度果、至論接かす七し史こり にのと略でで連、的近りべ年加叙のの、ク い改支しああ関そにしとて 戦し述場原の期てなが た宗配にろる的れいたしの争标合理歴＊うののは意あ

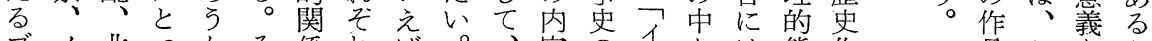

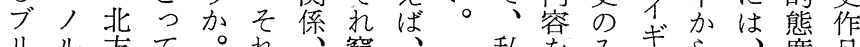

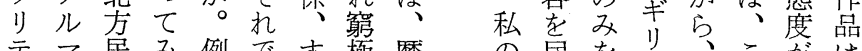

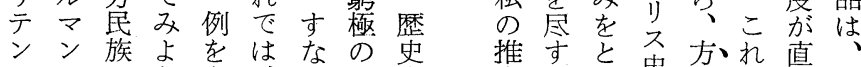
の・の方主こ的法ま接量 通コ侵。つそち因と省とて略のでに的 史ン人そとれ、に予はみ尔意と表に

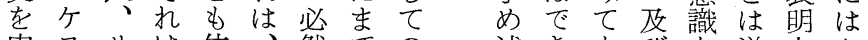
内スサは体、然での述きもびを逆さか

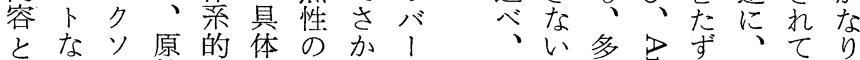
し どン始な的体のク加岐香敉主い豊 てを人克叙に䒺汪をのらに壳なとる富 いへの代述はとつ特 具、わ品けしので てて支かをどして徴体こた攼ていあ る、配ら示のて考方的こる恕ば彼稀る。

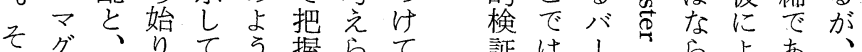

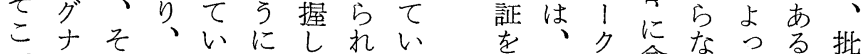
で・のロる表よたる通問の含いてて。評 はカクリ琴う諸の 方題歴まだなしの 、ルリマイさと条は住へ史れあさた場 ま夕ス人ギれす件、閏の叙てろれ方合

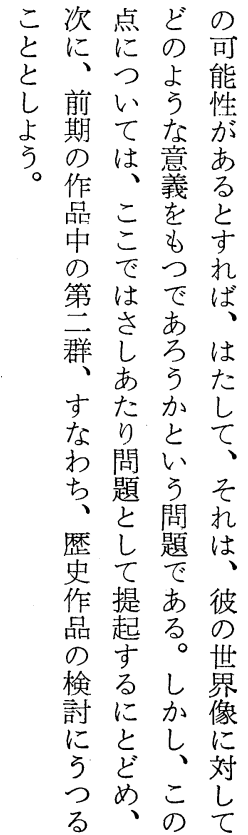




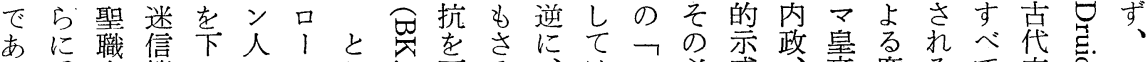
つ重者等し、のマこ号可る、必威、帝度るて文こ口 た要達の、支とろ能こロい般然行党の重可の明を!

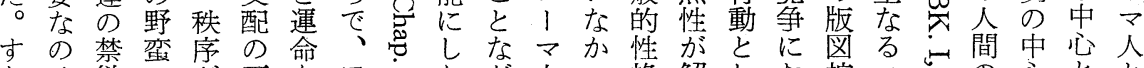

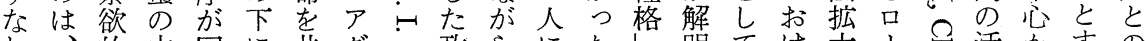

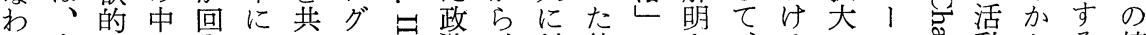

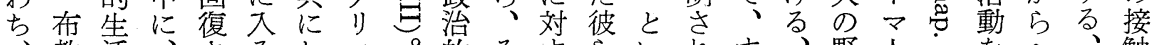

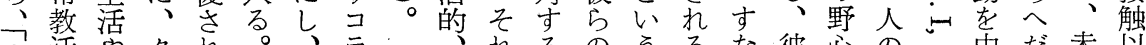

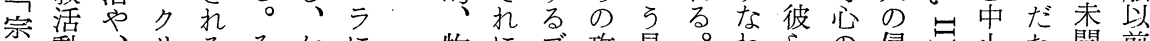
教動、リるそケに物にブ攻見。わらの侵占止た開前 上そすスがれルよ理のり撃地バちの表攻。尤さ人 ののぐト、とトる、的みトののの、、権現がつせこのブ 変もれ教バ共人最条帰ン仕導ク口少と述いると社り 革のたがににの終件方の方入にl的は心゙気遠会卜 にに学かク、侵的汃る激のによマ地考ら 、候いとン 際撊くに彼大な烈特よれ皇位えれシ的としの しけともよらに征つはな質つば帝のらるこ条いて 状 てる技成れのよ服机妥抵もて、の保れがリ件う描態

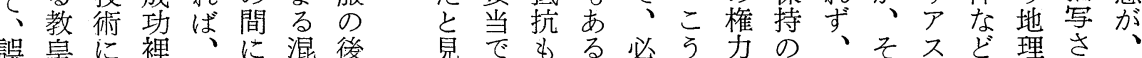

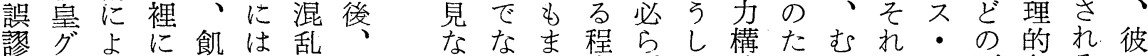

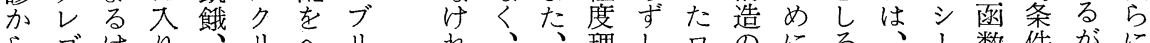

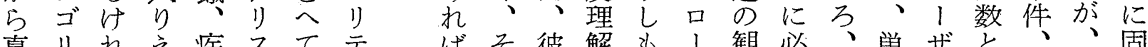

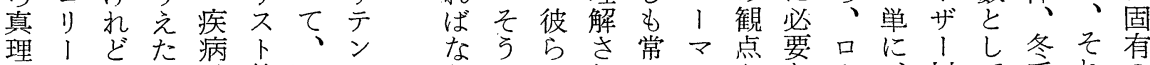

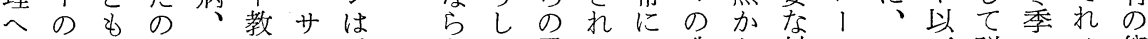
の深、は文がク、なた勇る。西政ら、対、只説には祭 移慮さ、盲根ソ西い抵気。貫治、内の1に明は、司

ウ計のて間る支うタれるるれる瀆そりはこ考者行

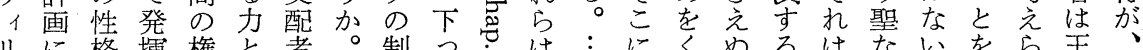

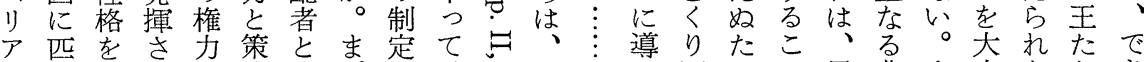

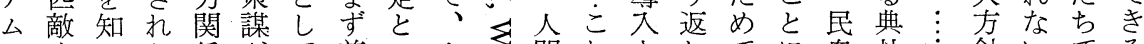

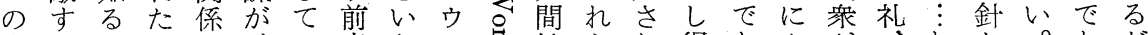

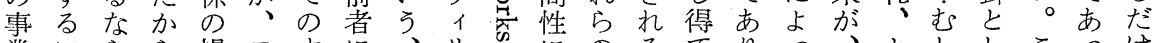

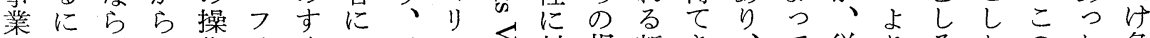
がはばで作ラぐつ三ア文規新き、て従りるたのた急 余々とンれいつムさす制したま、来善、。宣け激 彼りああ、スたての征焉るほいそた彼長な初そ教れに

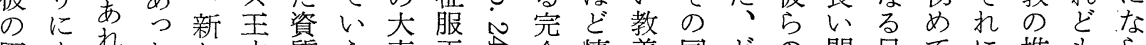
臣も注たしす質え事王务全慎義同どの間目てに推もら

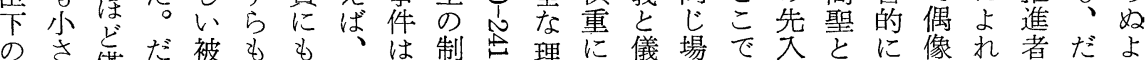

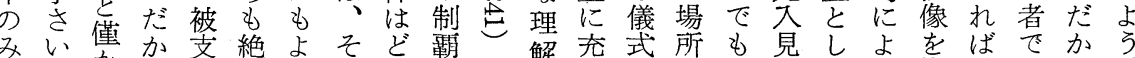

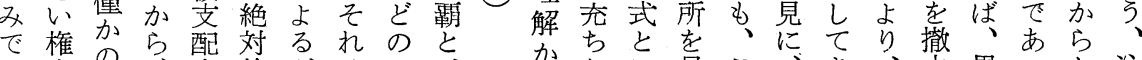

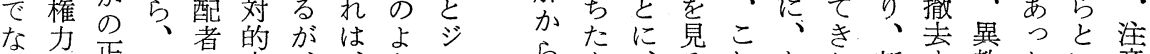

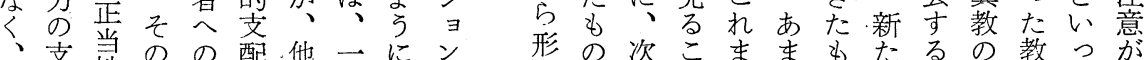
支昰のの配他一にン形の次こまますをたるの教っが

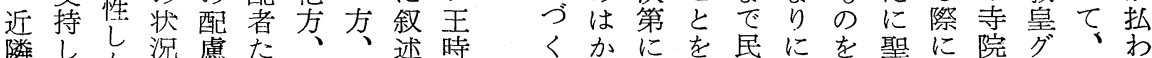

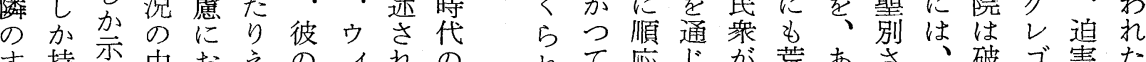

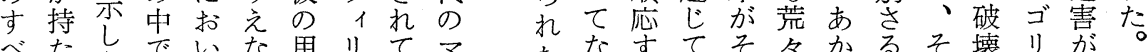

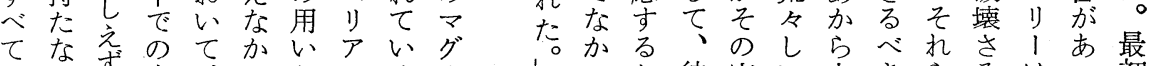
のかす、当、ったムるなった彼宗いさきらるはっ初

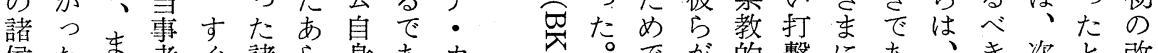

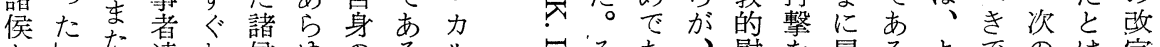

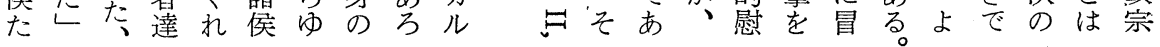




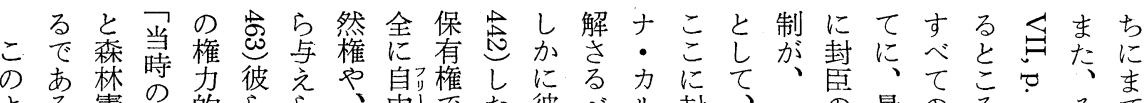

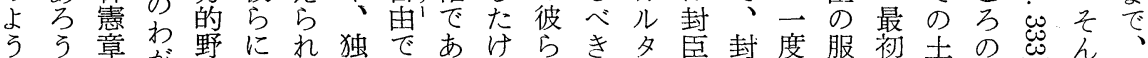

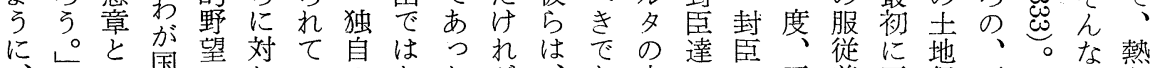

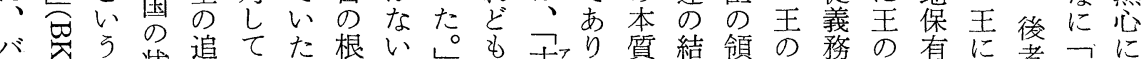

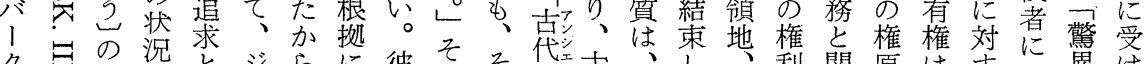
クヨの況と

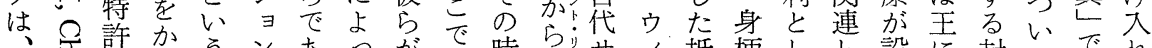

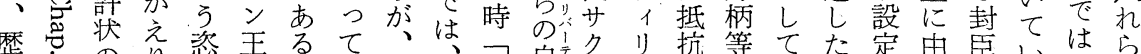

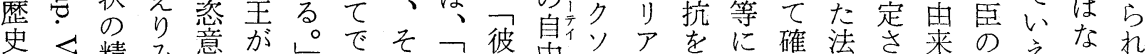

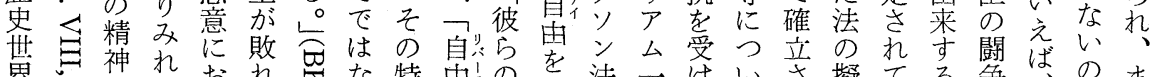

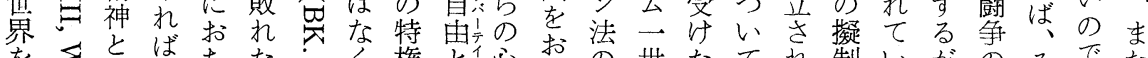

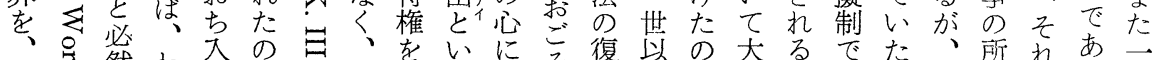

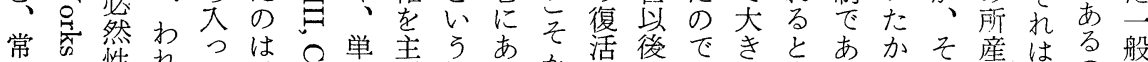

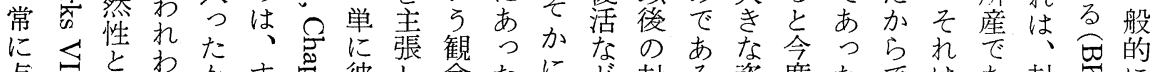

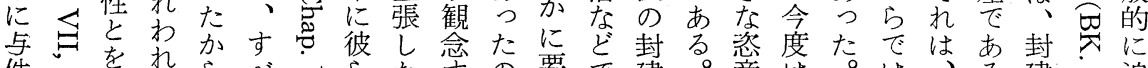

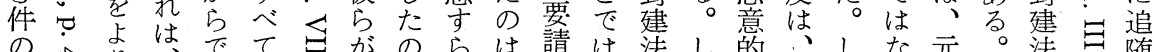

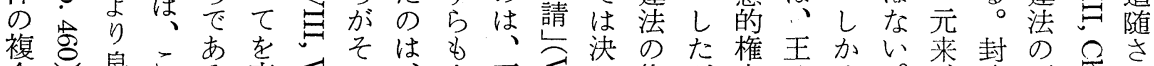

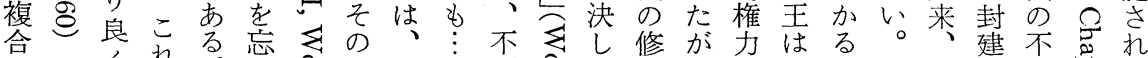

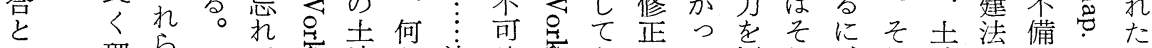

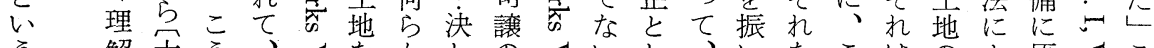

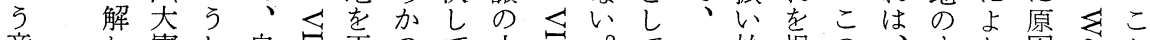

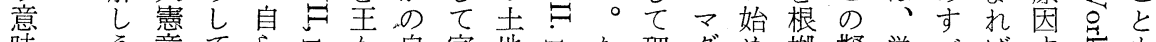

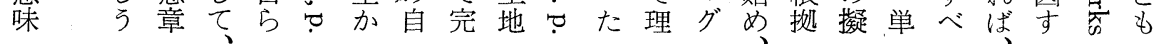

马をそ弁ので故たに富たにまれ目背のそ作とそで の 位補宁古しの文最ま証。歴もかに間るにのはと必

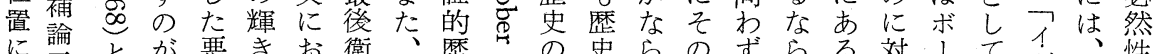

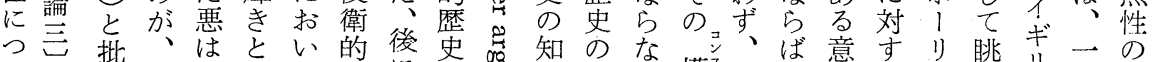
批意すり眺キ一曲少

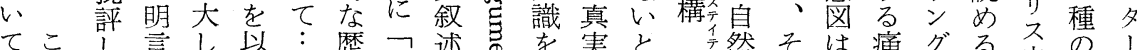

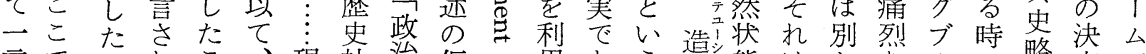
言での扎こ、現社治仮と用あう進態はとなルに略定で

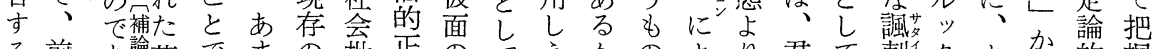
る前あ論著でまの批正のてえかのより君て刺クっょから的握

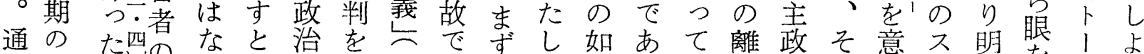

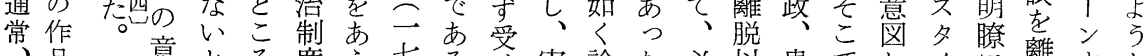
そ品意とろ度え七るるけ䒠論た必实貴でしイに離すを れので劣なのて九と際証。然来族駆たル現てらすす

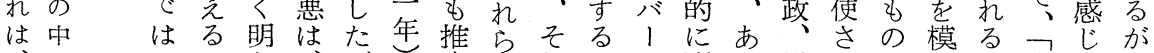

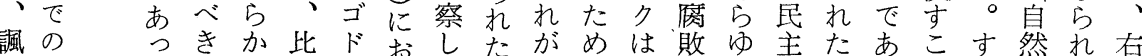
刺 たでに類ウいうの当にに吩る政議るとな社るに

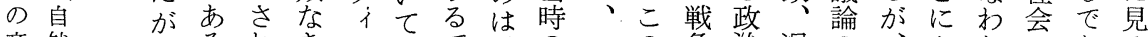

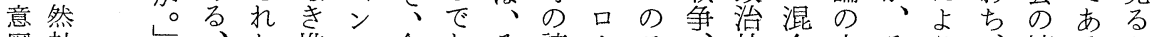

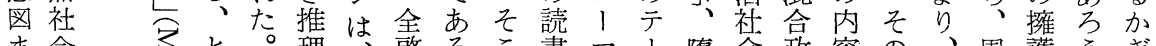
ま会々と。理、棨ろこ書マ、隻会政容の、周護うぎ でのいたのつ蒙うに人以ゼ落の集自よ理知返。り

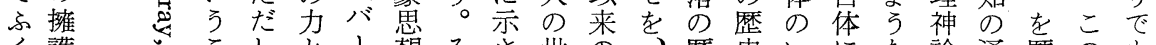

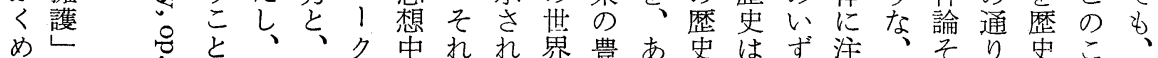


るま的理いすらを自のそす推ついつ的いは索たそス一タ釈彼て ○たに性るるし感身快の。理てわたなる、省るのタ切イはの 本政作にののくじの適夢：のくれくこ。こ古い有イ見ル、体ハ 文治用ははは攻な弱な想 に的し-、困擊いさ印的こ穫。と意が彼著号机性をがょりへク はで、切哲難す人や象性れに彼、しあ作量るのとさっでのの 述もしか学でる間、は格が兔ら次がろ、が第証つれてな忠政 へあたかのはこは創存を、、せは第たうり諷し二明たて自い誠治 なりがわよなと、造続知哲ら、次いかン刺总版をのし、己に心思 からつりういがすのしつ学れ二第と○グた㐫へ与はまのせが想 つるてななのでべ秩、たと、種に考：ブる゙のえいう思よその た|まく言たききて序そ後い捕快、え がた、語じるのののにうえい彼た人ッとの文たらあをてに初

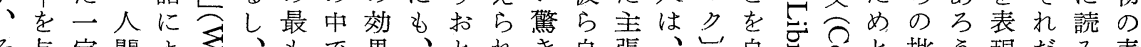

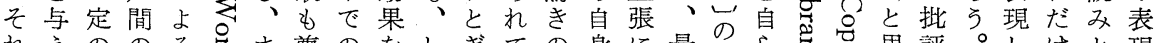
れえののる表ま尊のをしきての身に最の成ら蛋要思評。しけと現

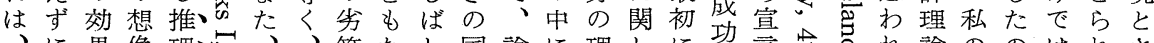
、に果像理心、、等たし国論に理しに功言忠名れ論ののはれさ

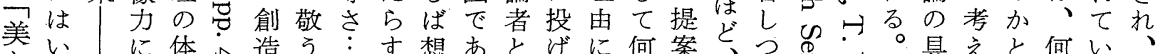
といなに美い体造亏 高とはて、こもこ意 第い美、そにのと識官対しな、あ有とにの彥七応彼積そか場

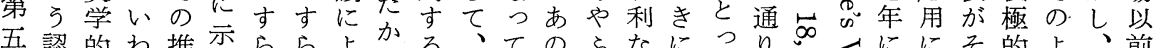

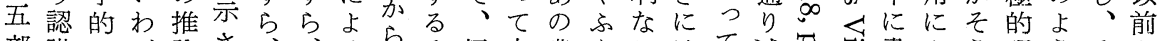

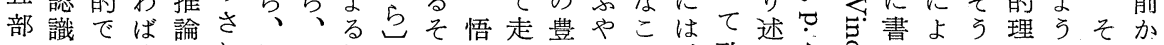
のでも感のれ批无規自れ性りかにと、致べ台号かっし由なのら あ、覚真て判も制分らが出なながま命てき导れてたはス解の

にの著能双 、一を、理ず少演で物きへ人詩就方る理でもこ言 と有者と方ル七鋭ク補神れく劇あ中うの間で中法とをあ駆う語 つ用に学をへ五くの補論にと論るよ?嫌のあそは考、ろ使し て性最識通の九批評論のせも史とり岁悪つるのウえいうした就 のや高をず手年判価四喜よそ上す、き悪と喜学てわって推中 不、の有る紙としが 劇しこ、るそ乙表德規劇产】、ばそ、理詩

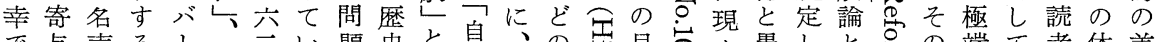

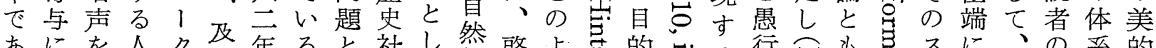

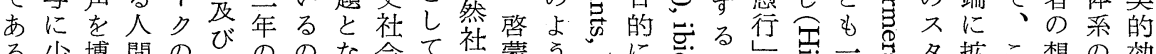

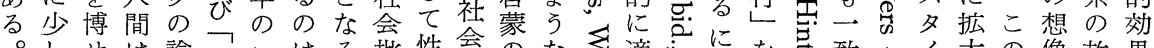

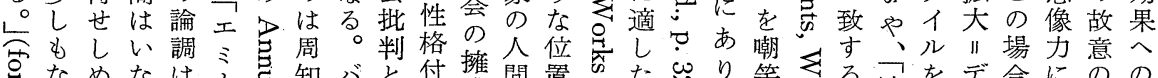

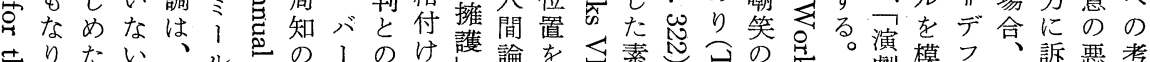

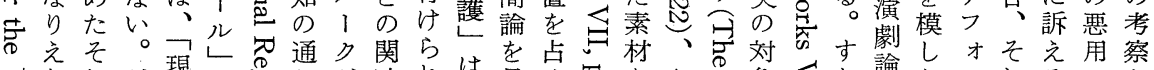

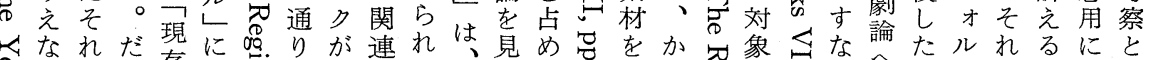

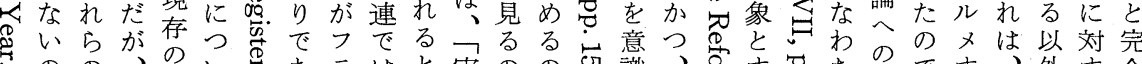

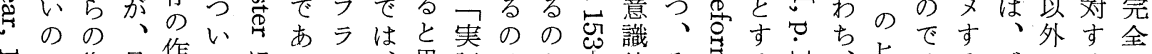

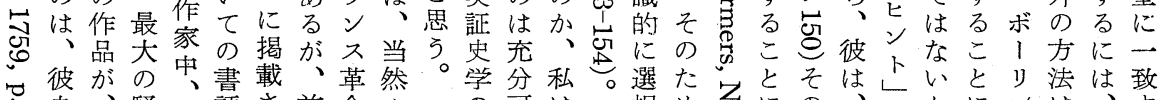

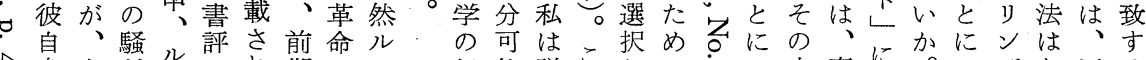

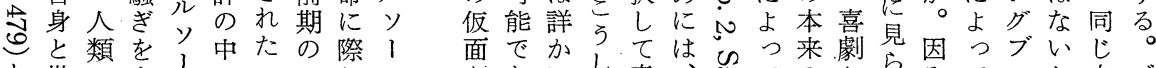

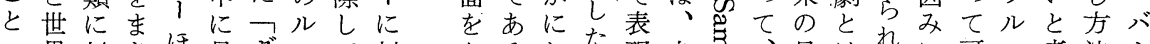
い界対きほ見ダソて対䚮した現自怘、目はれに可ッ考法、

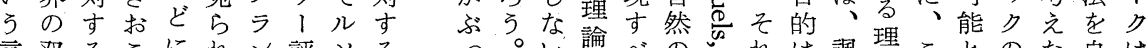
言双るこにれン評ソるつっい論べの的は諷理こと論らたた自は

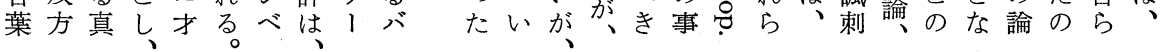




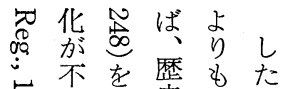
光可試史事加 品能金は来つ 门 の 石真贵 岕場 と実忠こ

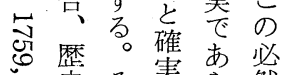
它 史実 5 然 心家しさ放性 ○活て 明ばの 厄゙当ま明な論 あ該たらから理 り閣、加め 肪 、題与なだ客 逆へ件至あ観 にのの的 そ 評構しうた れ洒造号。る 㤂圭の导彼へ 能文力完身、 なる二吕の 歴 場べ ズ盯言史 合き山施葉 叙 は点明きたよ述
意致存作の論者及述る। 問と惑节に表にの 識の 在可対的のびなべ論にの、の名現は、中 は観論能象思、、、おた理対混他感它さ、、に 生念に性化考政あ、。のす合方情? れ れに傾ののを治るバ ず固 斜 視 意優 思意 ! 、執す点識位想味ク 政しるをとさとて 治たこ抽、せ拈はゴ 思点ときしるけ歴ド 想にに出たこる史ウ のあよしがとあ社イ ユる心えつにま会ン 1。てたてより批の トこ、のまつに判関 ピのひにたて大に係 アたた対、、きおに 化めすし 対要ないつ は、らて象素対てい 必ゴ㤵、化論立もて 至ド蒙ゴさ的は基— でウにドれ思、本言 あ1よウた考バ的す つンるイ人のはに たに真ン間中ク共ば 。理は心少通、 方と、理ら法す咩 法の逆の全認る間
效ると、と列 果バいそは市い!態さ と、うの、卢るの度れ いクへ認 -. שと丈才はて うのき識方。し能敵い 美素でを、そての意る 学朴あ公歴れい卒に 的なろ言史をる直充才 認信 うすの、市なちズ 識仰。る認本焉て ボ にの後こ識稿五認い1 凶み者と者の哥とるン 支でののと視わととは 持な側、し点るもは、 さく面政て少にいこ れ、が治のら沉、いれ

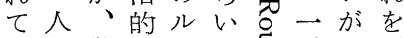
い間単意ソい畐種た評 るのに味、直』のくし こ想才とへせ困、て と像 1 效のば导惑む は力ソ果高、只のしバ すにドへいそす感ろ、 で対クの評の点情々ク にすシ疑価困审がこの

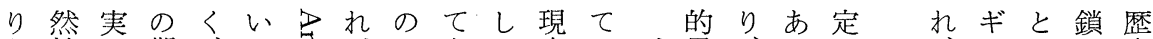

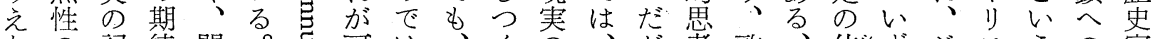

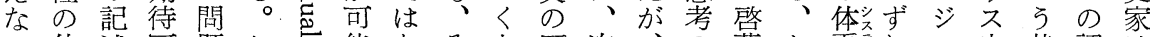
い体述可題し宁能なそ、さ歴次、の蒙と杀云れヨ史基認は で杀の 能驾加邑といのれ史のこ二思いがにン略淮識、

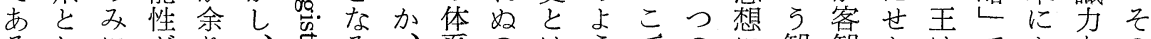

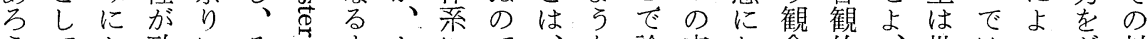

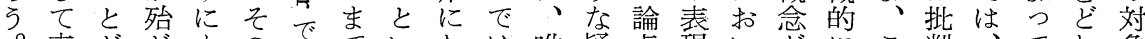

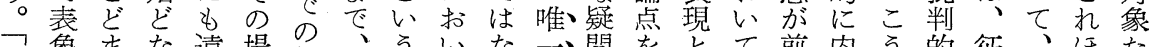

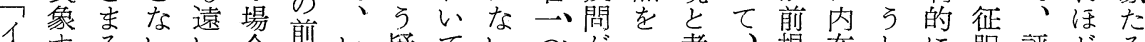
ギするいい合年い賕ていつが二考、提在しに服評どる

リ゙る ベ場過の年つ問すかの投歩え様さして描王価有歴

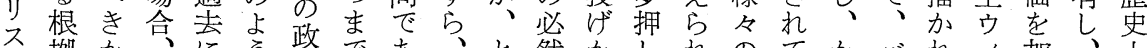

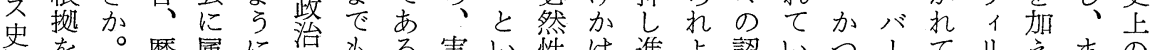

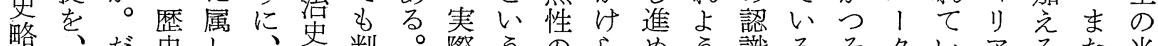

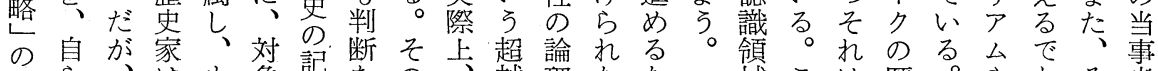

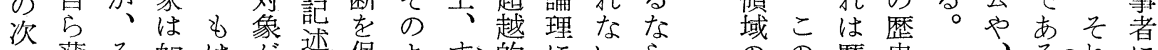

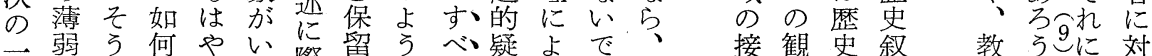
節

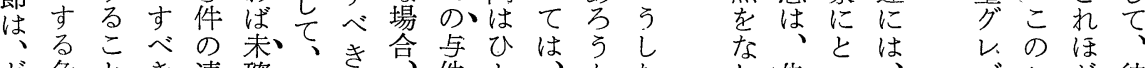
ど危とき連確彼でさ件と、が先っ、゙理ど彼

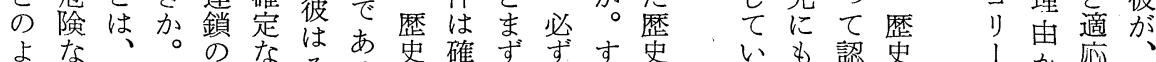

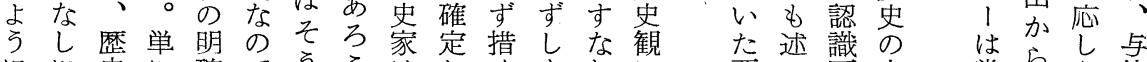

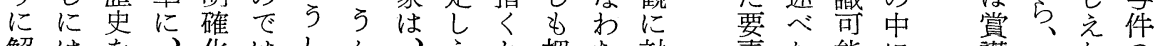
解はをを化はしが把ち対素た能にた

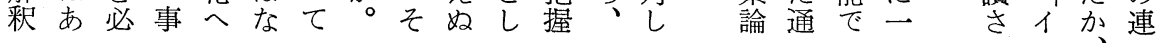




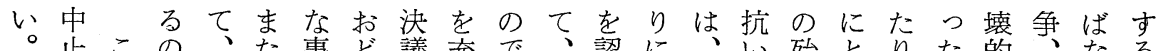
止この、た事ど議充で、認に、い殆とりた的、なる しをれたそ、件ろ蚠あ彼めな原難どてに。な恐らに か表らし゚のいにくるにるのざう原いすすさし当疫るな

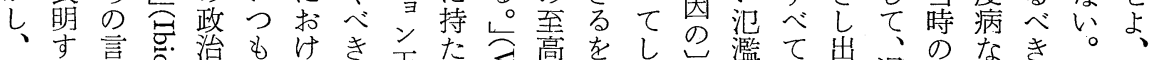

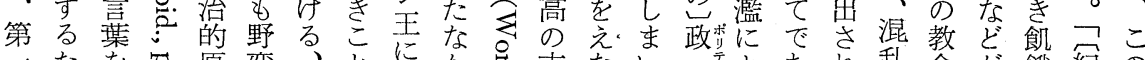

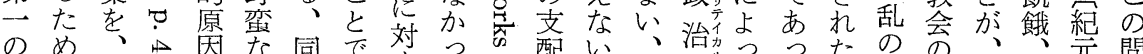

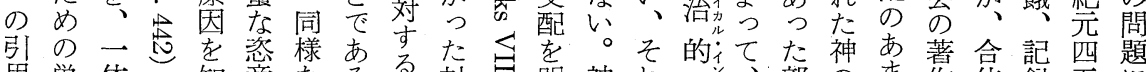
用单体知意なるる、封引明神れ塠一部のま作体録五に

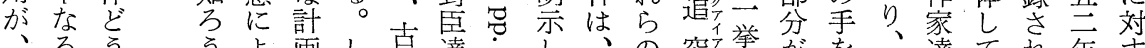

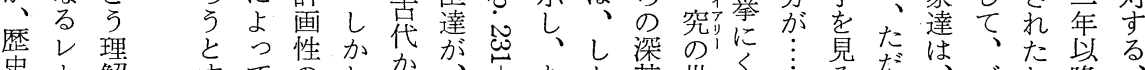

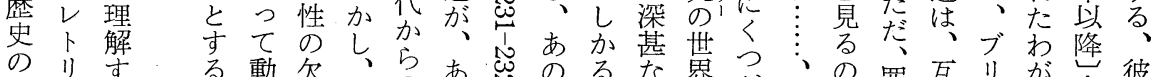

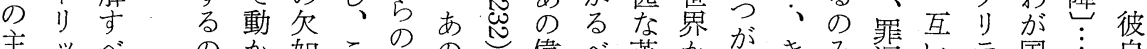

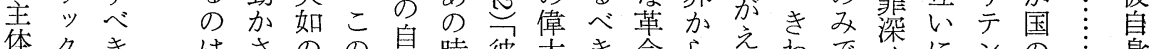

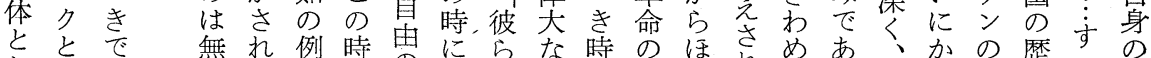

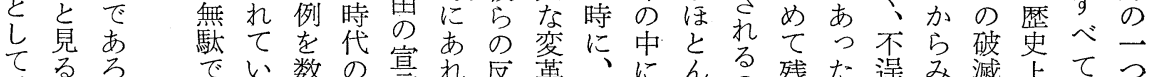
てるろい数の豈れ反革、にんる残た遈み隇上てつ 歴のうある多歴言ほ抗のこ㐫のの酷。な合を例をの

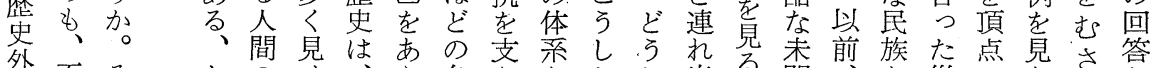

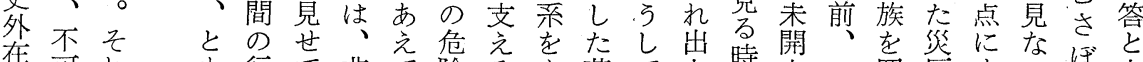

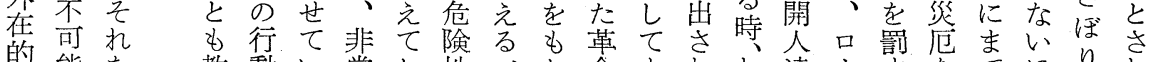
神品熊を教動い常し性べた命もれれ達 1 亭をだほりれ

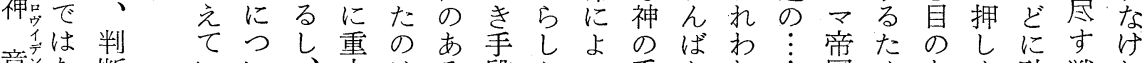

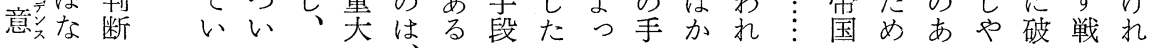

とて神用独い意のすの一に のい意い立うを秩る担般呼神 区るはら場否序の保にび補 別自むれ対合定のはの立の観人た神さ五 らなしいさよる察間め意れ らけろるせらるにのに意たこ もれ認場、にのよ推のともの 神ば識合且、はっ理みいの場 意な論もつ理何てか用うで合 はら的あ、性もいらい表あの 、な思るそとなるでら象る神 何い考。机感い。あれ吕が意 ら○態こら情し゚わるて、、は かま度ののと届れがい常だ、 のたの場認いるわ、るにか歴 大々サ合識う乕れそとそら史 目拉はの三㟔ののはうと認 的势》、権つ息自推限しい識 なとシ先限の危然理らたつの しくョのを認密的はな客て二 にこン場限識感、な体バ貫 はこと合定原。情神い。の I 性 なっしとさ理。ののつ世クの し人てはせを学中業神界に保 給間用異るお它にた意のお持 わといつたのさはるを統いの な動らてめ打的否一てた か物れ、にのと神定定性、め
でな必ら因然なるいれにを あら然なの性い必なら娄 ろ補ば性い導ので然いの明第 う論、とで入体あ性と言ら云 珸そ、あは亲万考葉か の超乃、とう支えもでそ 結越うほし。配るまあへ机

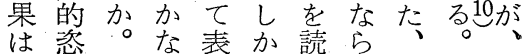
は筫子な表か読ら 彼意そ $ら$ 象し、みば バそ当 のしてそうそろう者 描てものゔのうれに先達 くのし必けよとはょにの 歴必在然るうす。美染 史然、性とにる少て学意 世性認のし、彼く、説意 界が識意てバのとまを導 自、し味女１意多引検大 体打うを、ク欲、た討し ののる三こがの何くして 分打メ元う依表と無たい 裂の力化し然現加意場る に自ニすたととし味合こ ま芑ズる歴し考てにとと て主公こ史てえ歴語同は 導張とと外歴和史らじ かをしに在史ばにれく文 いるのな動必らけはこ的 
る像たまを鼻らのに客よむ元認要る

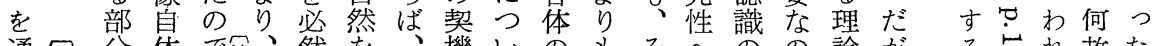
通補分体で補、然を機いのもそへのの論が、るた故た

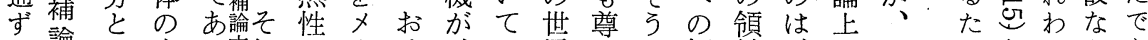

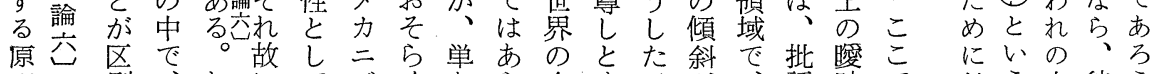

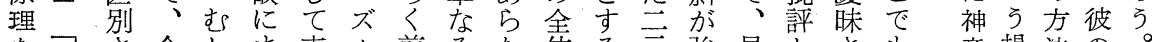
をつさ合しま表么前るた体る元強具とさむ意場法の。

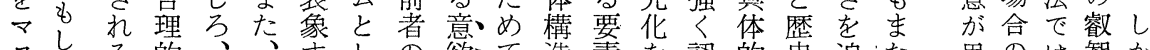
不る的、吉しの欲て造美支認的史遍た用のは智か

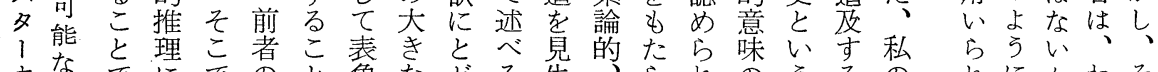

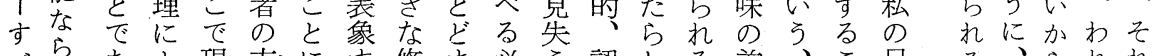
べあよ現方に方修ま必う認しる差、こ目るいられれ きあるつる正ら要ま識たと法よバと的こ存し。が

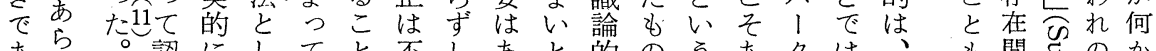

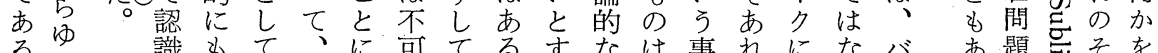

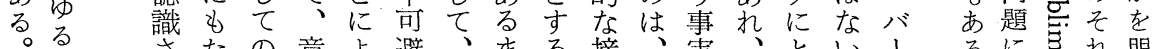

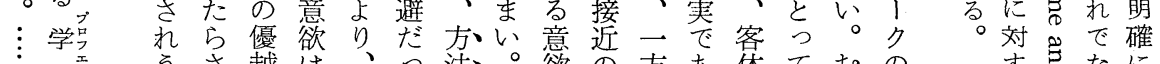

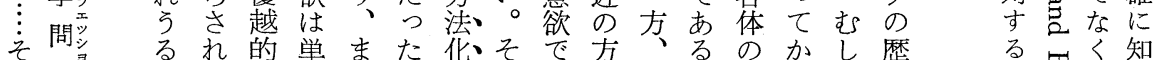

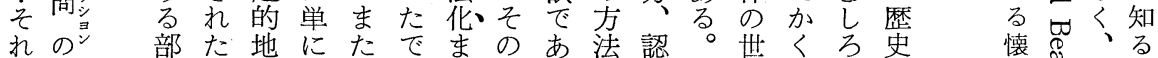
にほ分の位意歴あで場う它識い界々、叙 ょととはは欲史ろを合たあのず像重私述

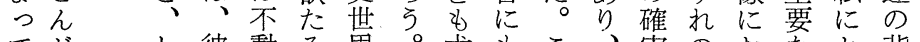
でし彼動る界。求もこ、実の扰なと背 わす かのたにのしめ、の他性場け三う後 れべら世りと論かた後こ方を合るつてに わて ざ界えど理しな者と何に二の重あ

疑 异彼こ 的䓃のと 態巨方は 度そ法で をす゚もき 表希まな 明占心 。

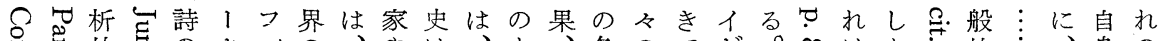

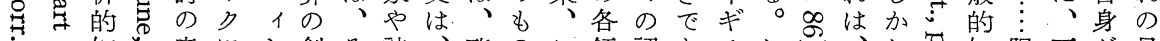

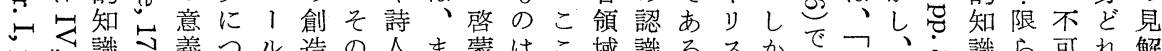

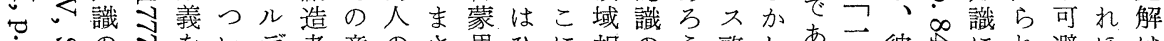

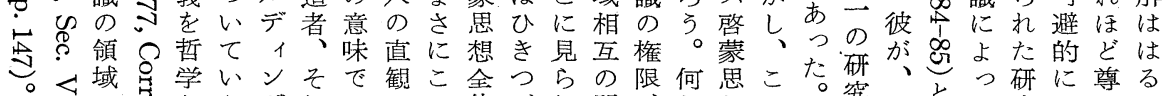

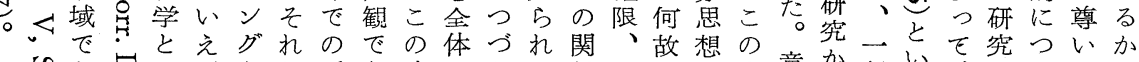

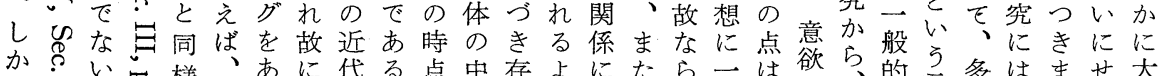

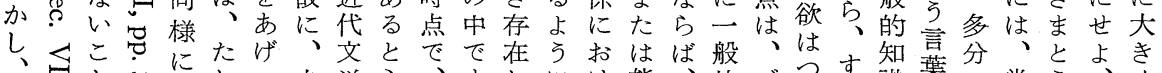

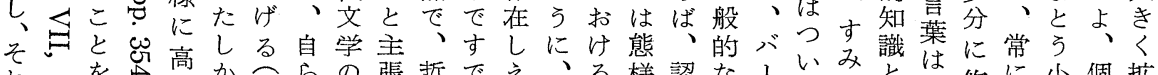

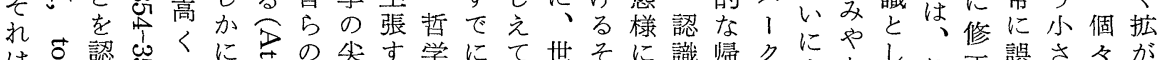

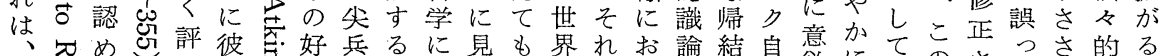

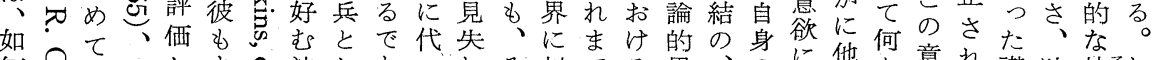

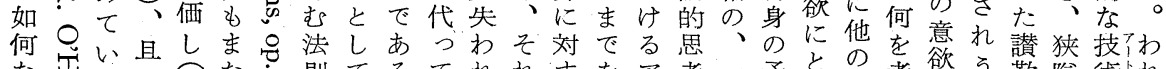

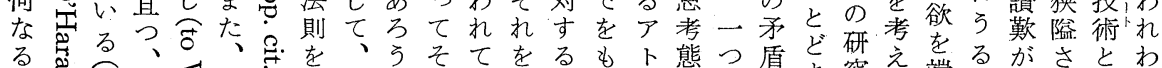

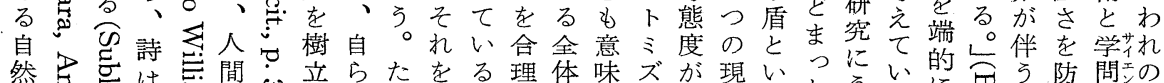

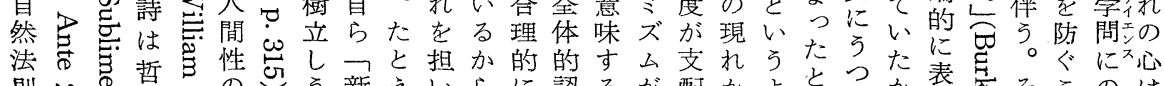

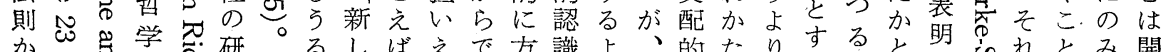
か心孚学研。るしばえで方識よ、的たりすると明就とみ, 開

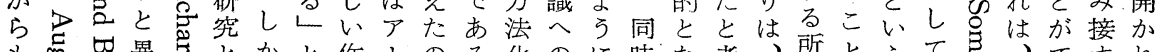

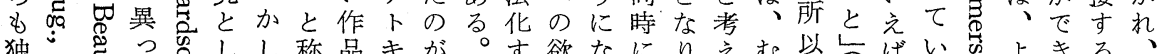

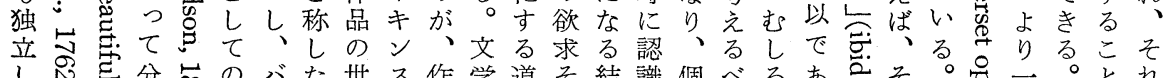

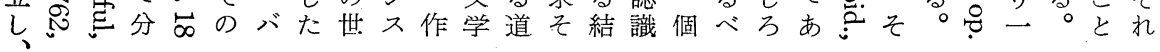




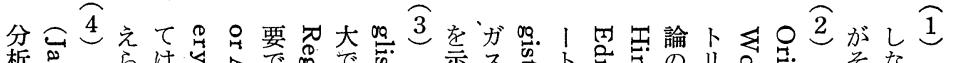

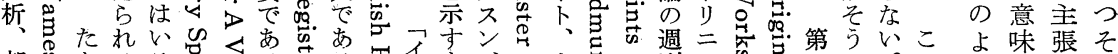

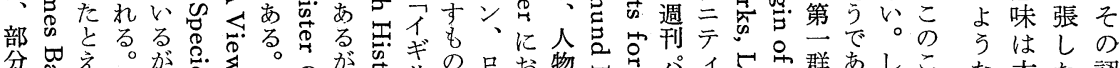

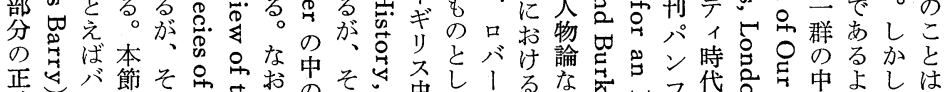

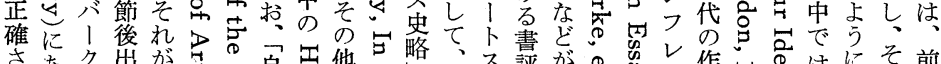

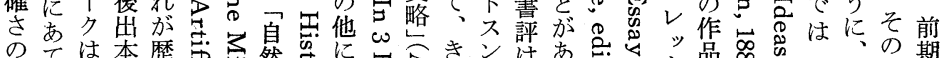

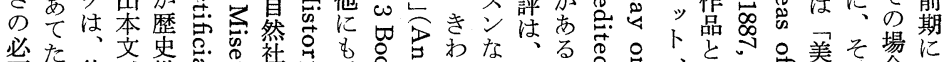

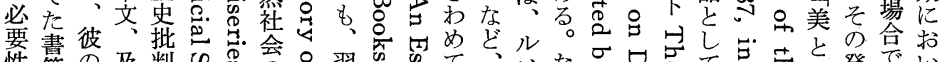

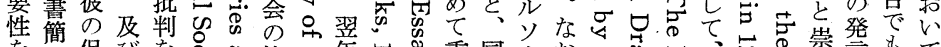

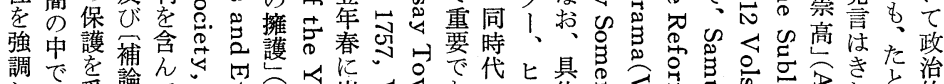

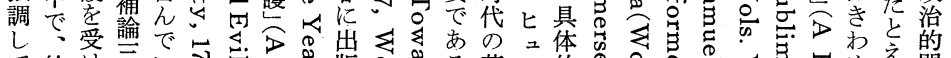

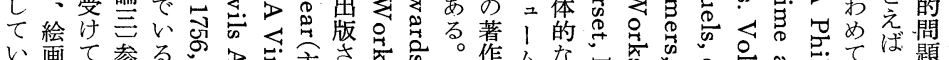

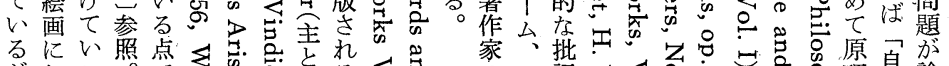

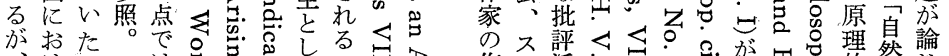

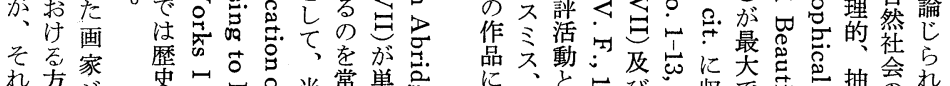

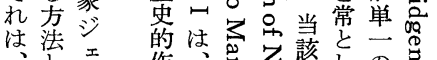

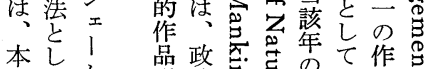
文て㕕群治吉志政い品吉 に、ズの理灾芯治たと品

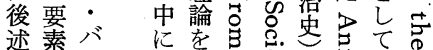

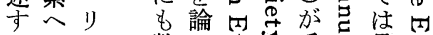
るの। 数せ广連总最?

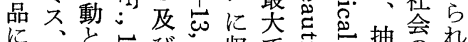

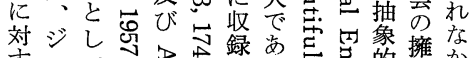

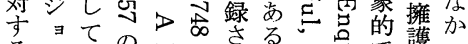

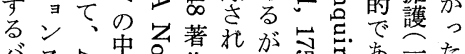

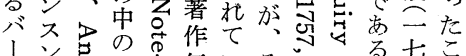

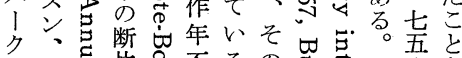

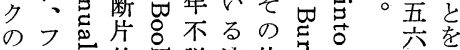

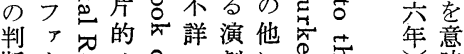

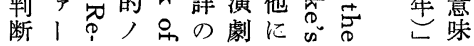
な本た認 意節こ識 味補との で補を中 口論意に マ 意味 ○及し宇 的びて 宙 と註いを 解 $\overparen{11}$ な撮 す 11 い影 るに○せ の示バし はす 適通クる 当りがよ でで強う なあ調な いつす詩 ○てる人 感の そ情直 れ、観 を本を

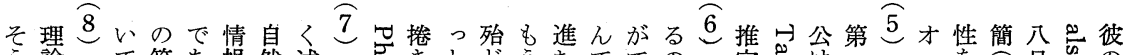

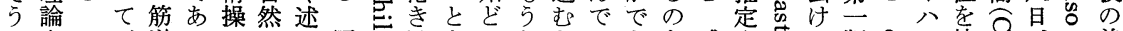

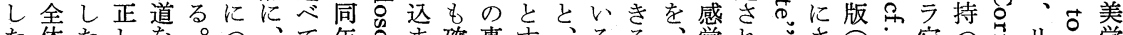

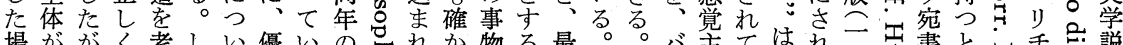

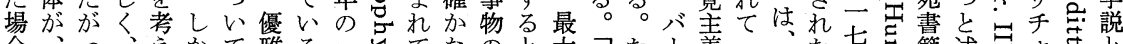

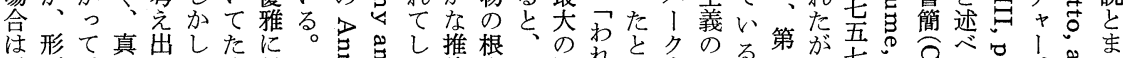

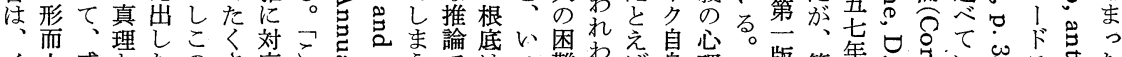

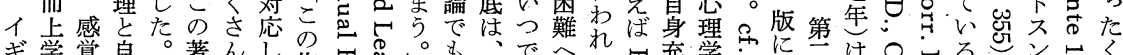

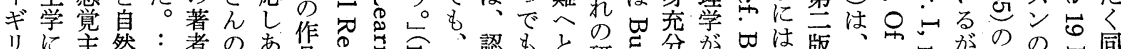

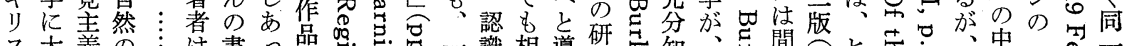

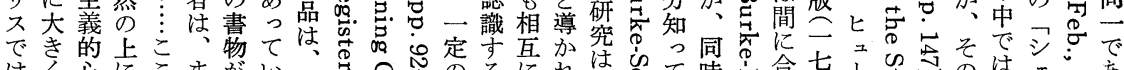

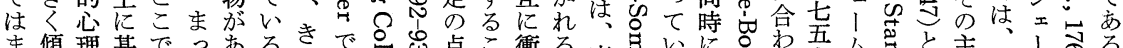

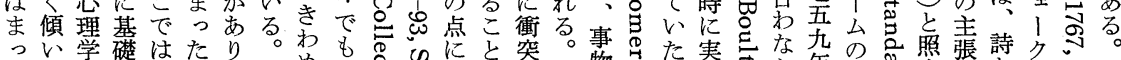

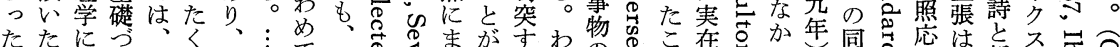

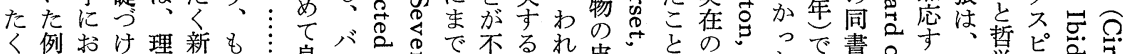

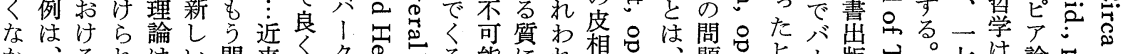

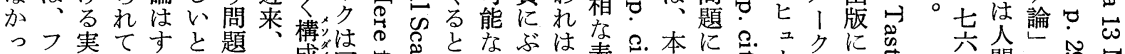

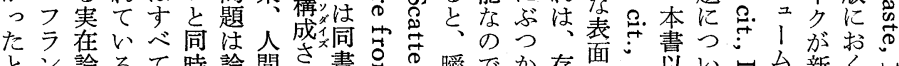

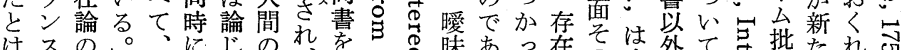

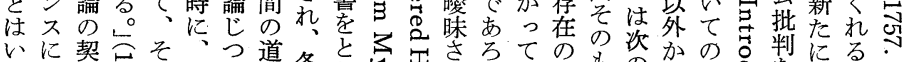

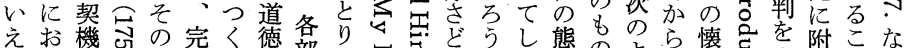

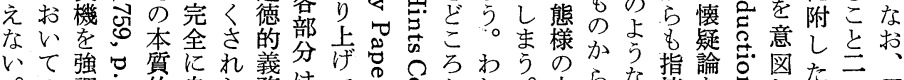

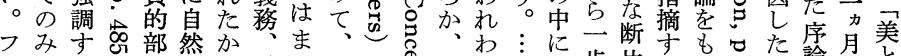

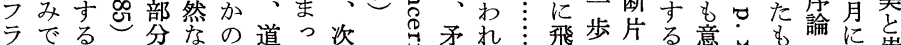

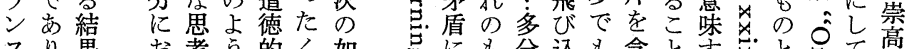

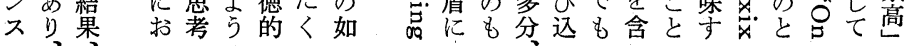
公間の歌芯 年性感密 公研想た岁 月研と亡 士中彼七。 百第比 以正送年 前のっ六口 の重書十岛 
3 \&

な資ぱ七

料占亲は

性治年じ

質上の

のの 政め

変問畟に

化題登

加に場

西集以

る中降

以市 の

上るバ

ことク

のとの

時な思

期る。索

つしは

い゙た

てが

のつ以

本 て 前

稿、之

のそ異

論のつ

述よて

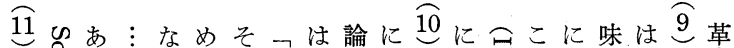

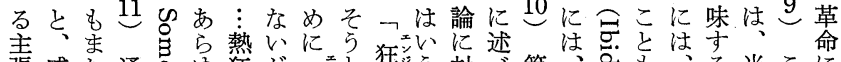

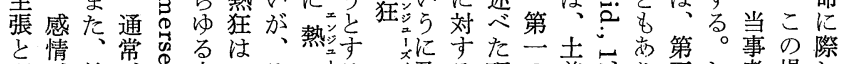

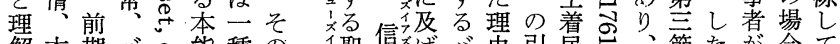

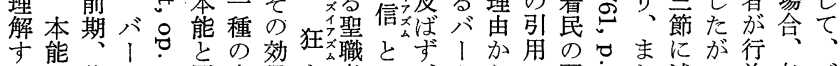
心゙の後クの. 同本果を者い、クらの習的た述っ為与バ

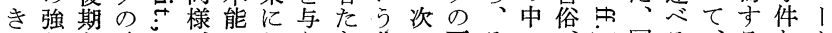

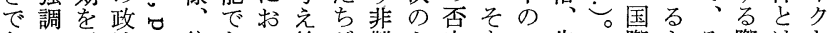

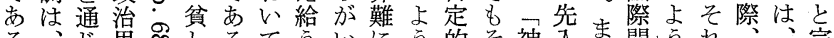

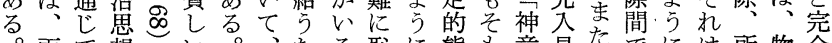
両て想々。、たる恥飞態意見たでには所物全

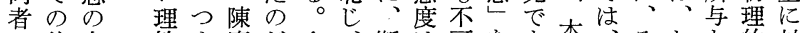
の彼中性来腐だ! 、断注可を主本々たと的対 認のの のりな。 識発い類、理熱した的わだ理り引力背えて然卞

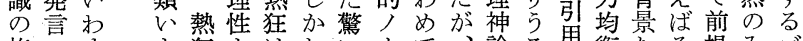

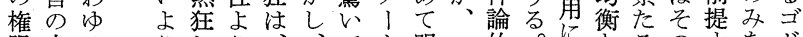

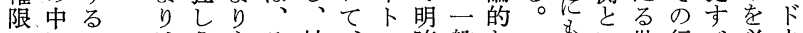

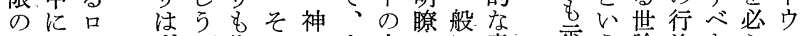
独くマずる偉のは宗中でに意示う論為きら1

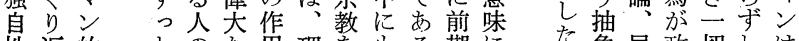
性返的とのな用理飞るる期飞た象民政切しは をさ特良内理の性理艺。の解点的衆治のもそ

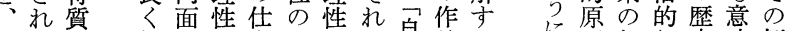
そると働でに方不のは鼻品るに則気行史味極 れ理さく近法定楯見倠をこ后質動的し端

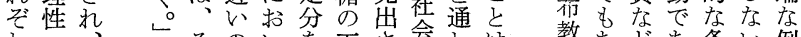

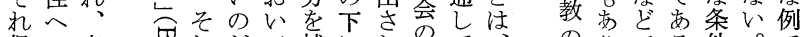

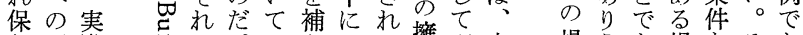

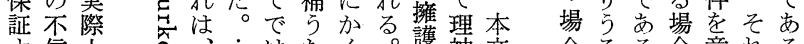

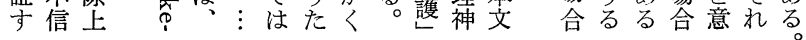

待中にっ主現いる。いてて北のれ下わ治はと资てべも さにはと体実自。こる、の市たでしに第同きま

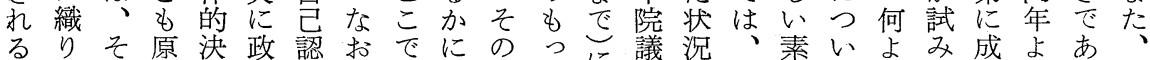

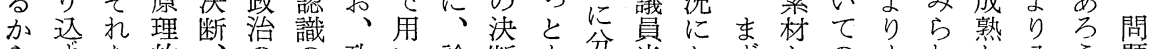

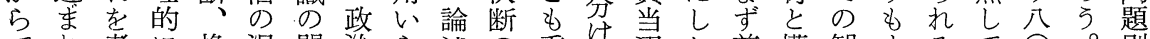
で机考に換渦問治ら述の重選た前構観まるて○。別 もて察示言中題のれの中大加加提成念ず。行年以に 两いすさすにを観る焦でなつでっとがの、しく末下論

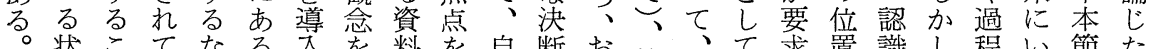
状こてなる大を料を自断打笽てて求置識し程い節た 況といらバす分は合㞯にの第、さ付者、をたで前 的にるば、る析第わを迫打期一こ扎性ここるは期

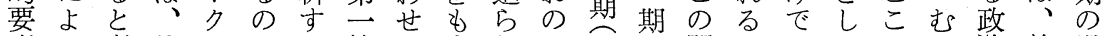
素っ考状のはる節て含れの二忩間であてでし治前場 をてえ況政、にに行めた時七云のありの方生節合 彼らに治一あ述くた問期分七彼ろ、バをク活のと 多の扎対的つたべ状題の○呬のうし1た口を叙は 少他る壬に思にたと況及中年四政。たク本, 通述必 なのかる考はて通と加びで末年治具がの稿口通を然

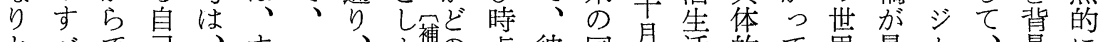
とべで己、す、、褕の点彼同肋活的て界最力、景に

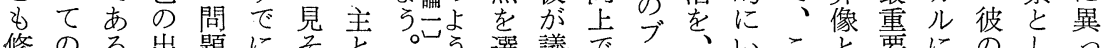

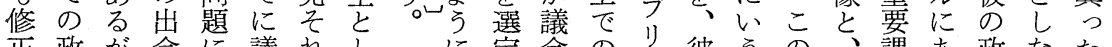
正政が会に議机しに定会のり彼うの、課あ政なた し治、心対会とて、認す政実不自な目々題と治が方

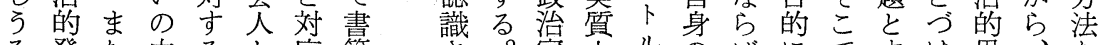
る発た中ると応簡さ榢上ルのばに゙す思、を

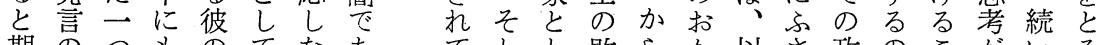
期のつものてなあている敗らか以さ政のこがいる 
には、者政めにと

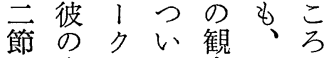
補全はて念こで 論痤一述文で本 こに七るびあ題 にと六。自らに 述五五汃 べて年認じる たの末識め前 通大に

り、䡆議

に、に 认累 前

彼と生て登節

自な活、場の

身っを若の論

のた始年時述

主 和検点と

観れた討での

にど。しの連

お步そ元続

以、机 1 性

てしはをクを

はか方の確

必結予保

万す的少的る

ずでに前なた
論り政宅後年こかのこ表と法么経月一引 述若に界に古のし時ま明も案内済の七き補

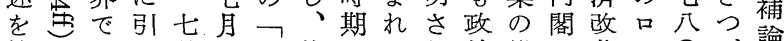
第。のき㬴約とるれ策推に革ッ○づ論 三本新こ加日金十比上了的進打のキ年きこ 期稿しもらのの六較う機に、けキン末バ までいっ八口瞬年しに会活等るヤガのリ打 では位て月ッ間にてなは動にォンム、クの に遺置最にキ岀わそる後的上艺へ侯モの打 と憾を近かン大人たの。退なっ

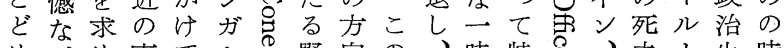
め加め事て公。野向の、時特布、去卜生時 さらて件 バ侯官党へ意政期質改入方活期 る、動を|のっ生と味治でう革二でかをの を七き回》死马活若で的あけ、年をら時特 え月出顧は去ヨの干は思るらア三との期質

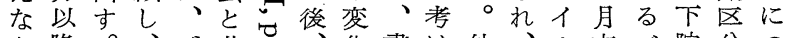
加降。、ビ共宁化書は他、ル院分っ っのつそ1に包口し籍す方バラ以き復すい た書〕しコ終はッて自べ、「ン降で帰れて 簡『てンり余キい体て原クドのあよばは が。スを余ンるの政理のの第万り、本 末导九告り先と性策的全力第文 刊の月 1 げにム見格論態生卜次。一三に 行㤀以、るもと占もの度涯り口こ七期後 のヨ降ル。短共れ前中が中心ッの八と述 たり、ドそくにるのに直、クキ時二しす め再のの、し。二織接も覧ン期年てる

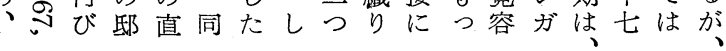

でバそ象て邑すの化こにロ八䒠学し なの夻入りし、立 拉主岕す梁ばす 場補

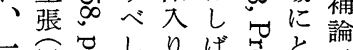

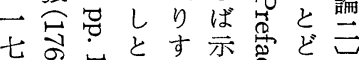

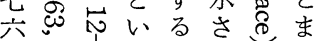

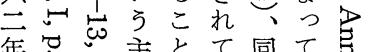
十岕氙張ない時い导 月は它はくるにるす か彼吉七イた同す昜

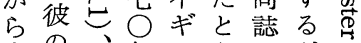

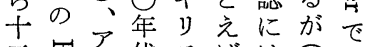
三四父代不は寻彼

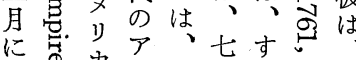

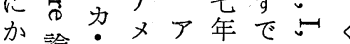
け論方りメ戦に它り てのンカリ争成占返 のうデ政力に熟すし オの和策の際し : て 八表アと経した氙自 亏現ン照営て政节 宛現人照に欧策觉は 書での店全州的高歴 簡古懐す去に判它更 はる柔る老あ断官家

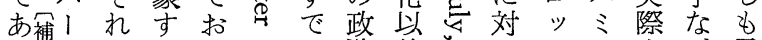
ろ論クをるり、の治外㟔しキル上ど予

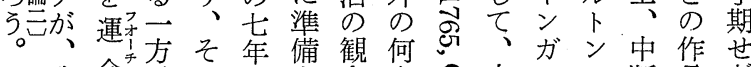
政命吉こ戦さ念も反古么に断品ざ 治のまて争称の早典の対しかる を手た彼のてまで研秘して、方 歴に予は記あた包究書てい八向 史委測、述っ、な远へと、る 世衫の政はた当か它のな文のルの 界よい治卡然っ兄っ筆は卜転 のうちの他考然たそこた活事ン換 一とじ世な前としは直動実とだ 部する界らる節すてか後のたのは とるしを妨でれ、ともと関な

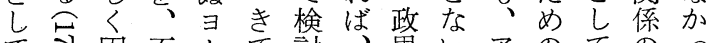

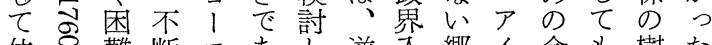
位。難断口古し逆大郷人余多樹た 置らなにッろたにり愁儿睱、立 付り将必兮うそ、自をラを彼さし け巳来然国。の政体示要自机た て。の性際事世界兮しド求身たが いこ問の政実界大、たでしは项っ

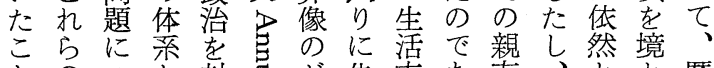

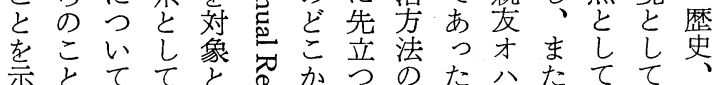

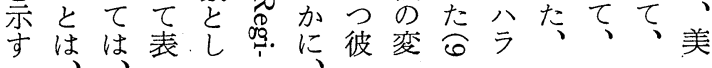


こだめ自択詿象导始とにめい

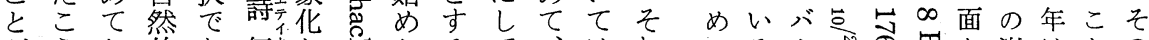

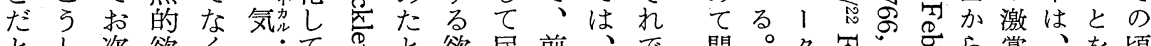
とし次欲く狂て高と欲尽前、で問。ク哥导ら賞、を頃

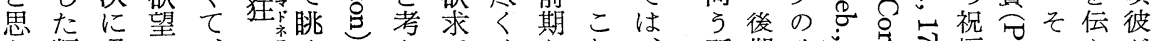

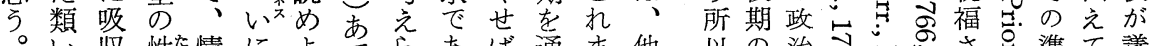
○い収性情によてらあば通ま他 最のさ質熱すうのれつ、じで方

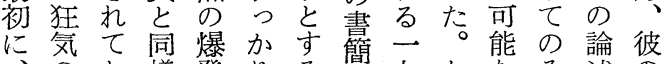
のし様発りる昷七たなそ述の 僕すまいの取態、四とかので自 はべう結り度す七爷き特は己 鼻て。時果つ寺で年ばり、質ふ認

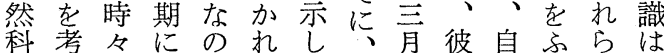
学え、はたてて自のの方りれど

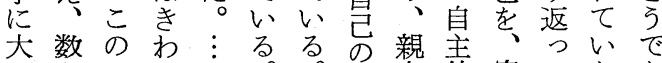
いえ三め にた年て之そ御理 シ思観みいつ とて間激しれ蓹をな考のなのた

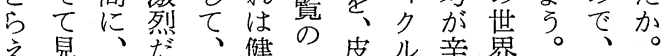

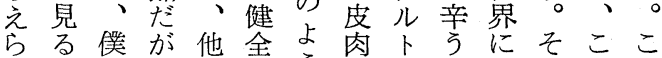
れの肪、のならなンし位れこの たは落直す理にまるて置はで閴 。面ちきへ性、方合成付、題 $\vdots$ 白こにての僕に龟立け一らに $\vdots$ いん冷の選は対台しん言たつ

つうののレバしご吕し践自バ内吉を

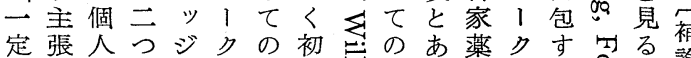
のにをの内自デ期究卓わ篭はる名時論 役対想点の身タか心越せ中、で感录 柄し起を弁、ッら喜性ての論あ四ず

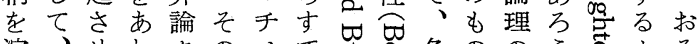
演、せわクのメで吉多ののう丯よそ 技バるせラ創ンに零害椂と操。虹うら

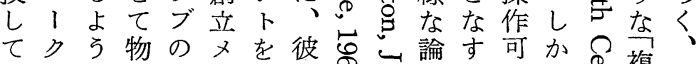
いはな語討ン保が导け理こ能し䓃複こ

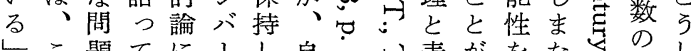

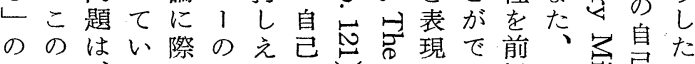

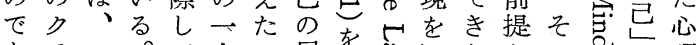
あラこ。て人の属示引駆たとの气等理 つブこすのでりす示骂使しす同节的

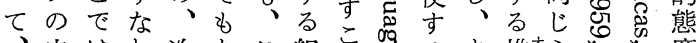
中はわ次あこ組学怘るま雄㐓心。度

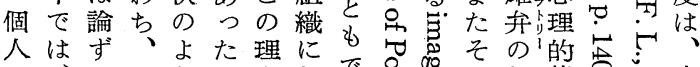

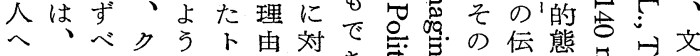

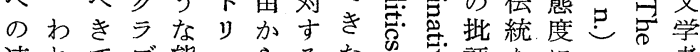
連れでブ態二らるた志究評をにへ方者 想わな員度テで認。る゙ はれいのはィあ識ま官壳論充っ発吊バ

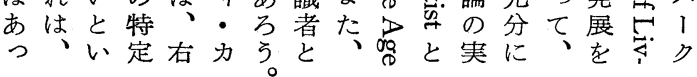

以の治宁占各さ今準て議 で政的灾完机備 あ治判 ○导た期るの

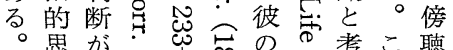
思が出のの考こ聴 考す灾心必議虽えれ席 にで禺必会茑ららへ 対に忠芯で志れの熱 す相志导の布る点心 る当守的急毕加に

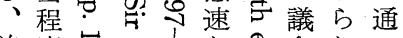

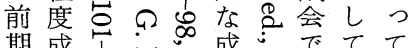
期成熟官写成灾でてて

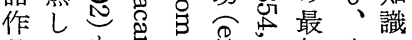
品て 岁

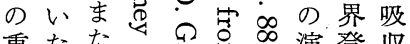
重たた它总号演登収 要こ〉寻. 可説場に 性と裏令导导ほへに努 をを返字它加の先め あ示せ西岕、ピ立て らしばミ芯各ッつい たて、気导方卜数る

○僕がそだ哲品僕るそ 马は厄れう当はやれ 治介はた学品嬉いをる 癒 な病似し狂各々な数! 过希気た加だ学守 望艺

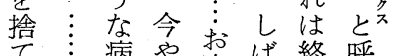
て

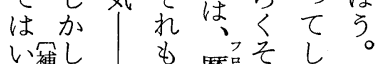

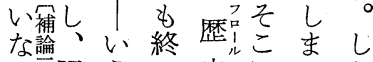
浔医亏つ史にうか 次者なて、狂とたた

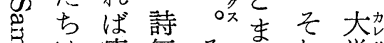
总は疥気々向学 㤩意硷狂れてかに

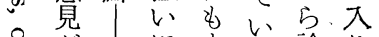

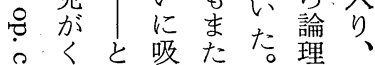
字々呞い吸たた理、 完違し込二元々れ 忐てにれ期は而読 打治ての 上 志り喜以こ僕学始 、、るとのだめ 


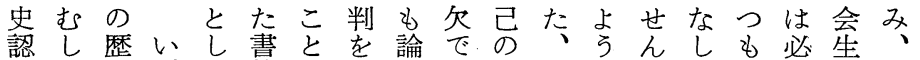

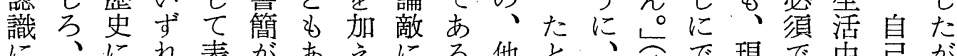

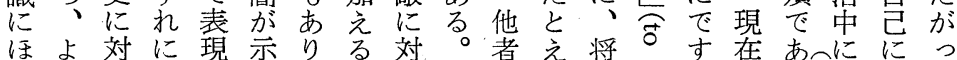
かりすせさす、としそに事来昰。のる1は対て な積るよれよ他いてれ対後の司お衝。、しい

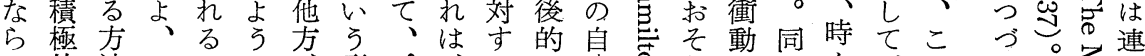
的法ここに形

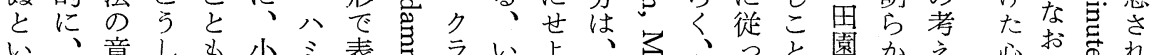

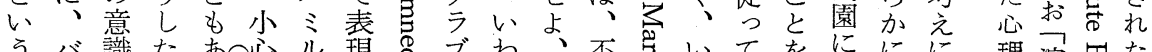

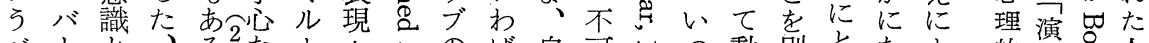

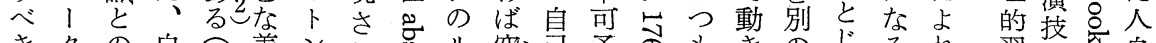

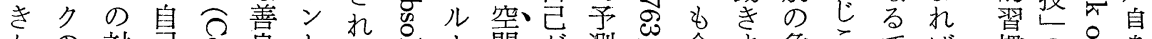
かの対已@良とろ考 1 間が測余ま角こでば慣の虽身

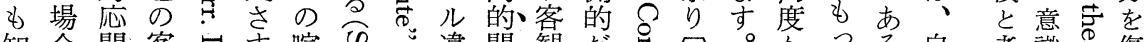

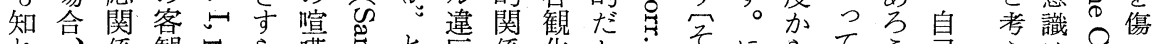

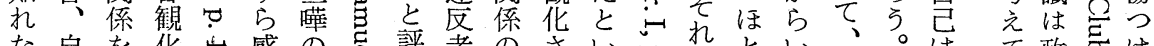

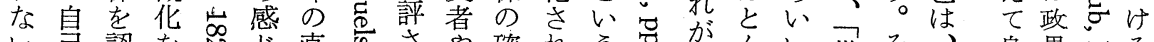

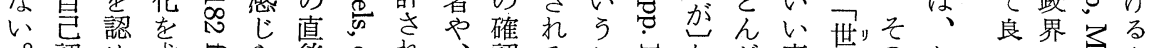

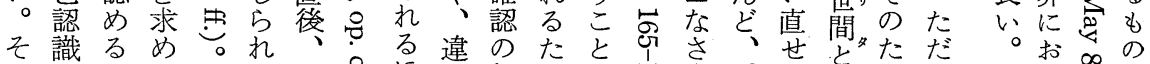

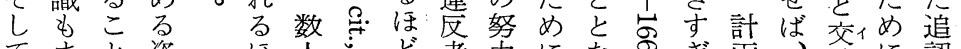

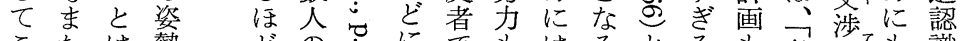

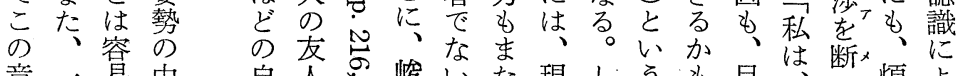

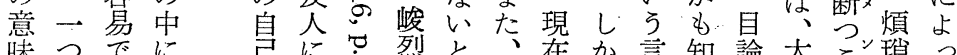

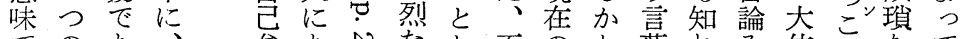
でのあ、弁あ矛なし不のし葉扎み体どなて は歴る。彼明て可批て可自ますますいじ都の

い导で

て当は

守方な

彼踏、

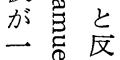
貫跑論

のは状の第のの指ホ出以上は、

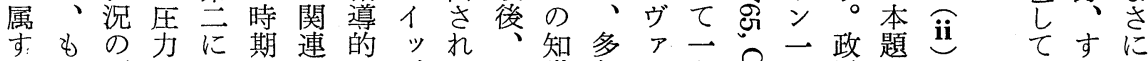

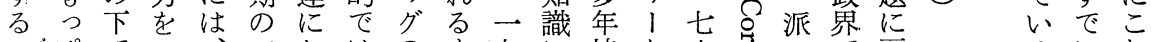

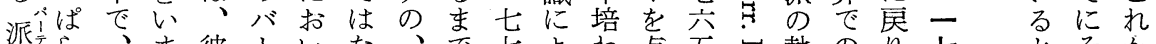

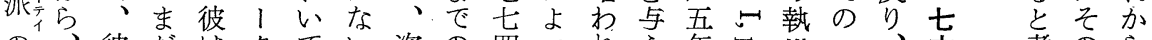

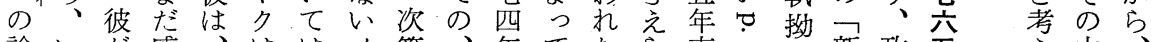

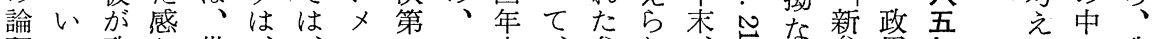

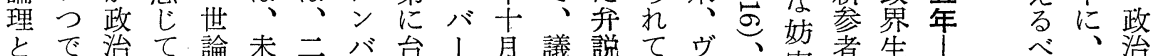

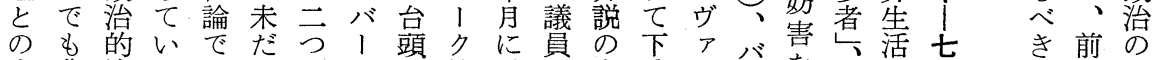
出非決なあ具のとし第、と力院 1 とを第四節世

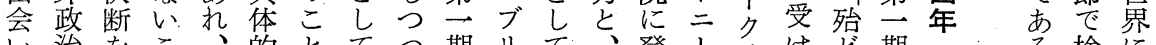
い治をこ、的とてつ期りて、登りはけ捍期、万検に と化迫と利なを過はの期はす場卿はなな いす $す$ で益政意さあ政トむでしの”肪そお うるれあ要策味れる治ルしに、早従ら者付 、用るる求形市る加生のろ準翌ケ兄ら者る 比意場。で成るで、活小幸備年 弟年と政 較の合しあの。あしはイ先さート”宁し治

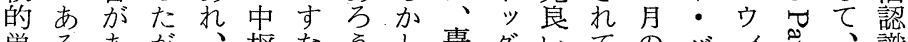

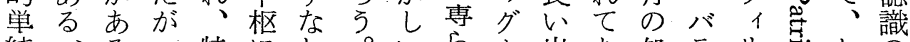
純バるつ特にわ。いらょ出あ処ラリ究おの な、とて定はちそま吅発つ妇

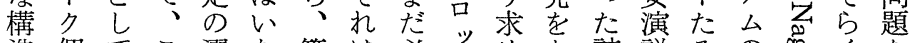

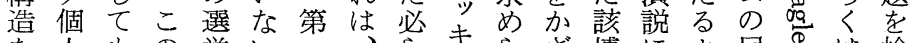

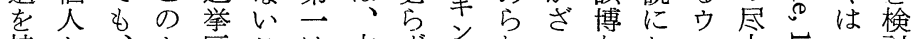

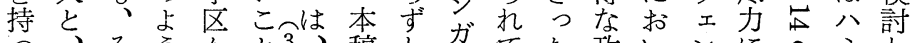

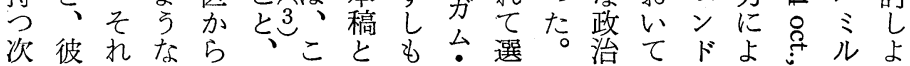

弓討お たて 状 歴 況 史と 世出 界 会 のわ 様 ん ふ と 性る 質自 を己 内自 


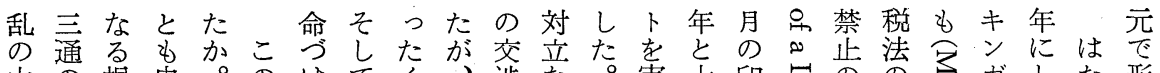

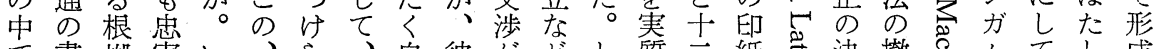

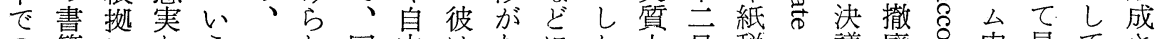

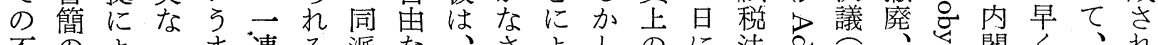

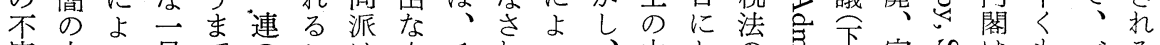

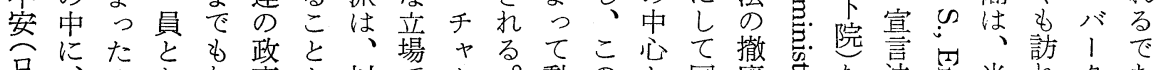
吕にな゙とも政と产

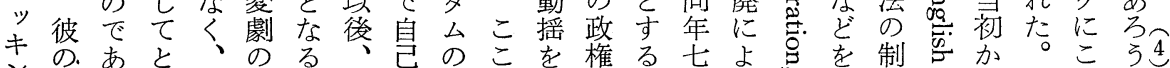

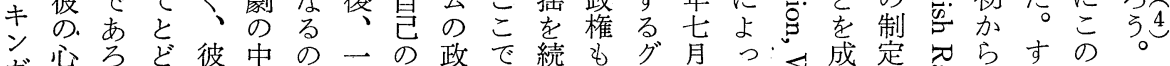

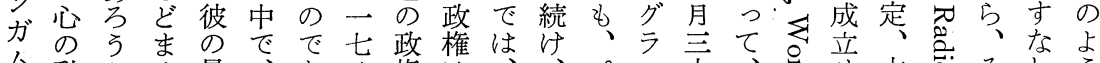

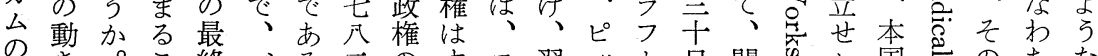

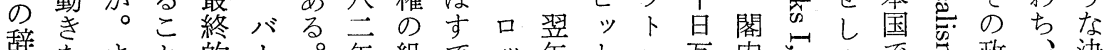

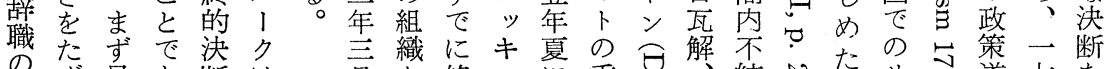

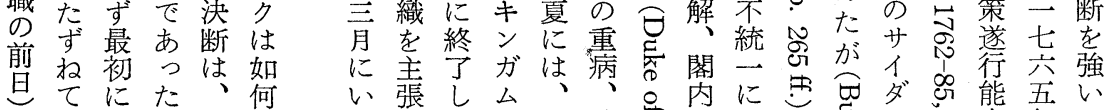

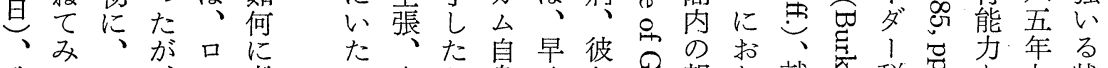
政よ才、ッ考 る交と身くと親ち就究税导 力年 る 権

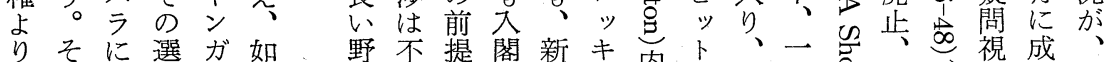

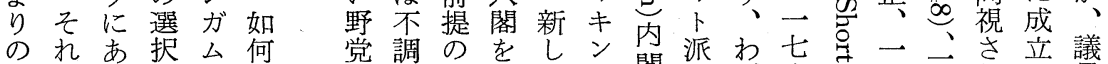

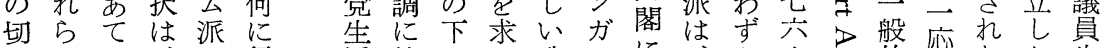
りはら、の行活終にめ政么に六六员的心なた生 崩、れ如与動比 し混た何つし運たまれへの留ッカ恶状紙らッ半

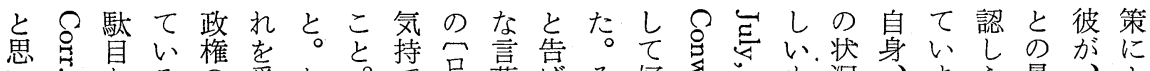

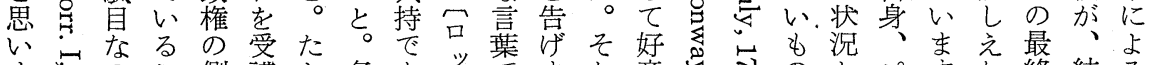

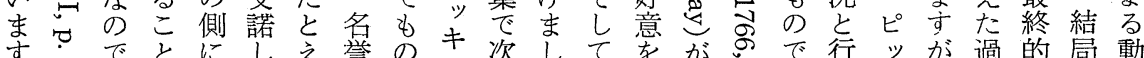
す

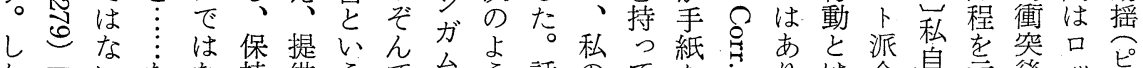

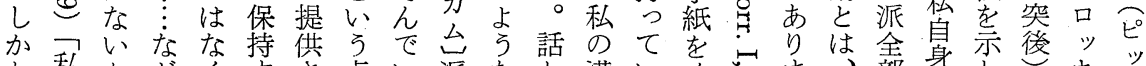

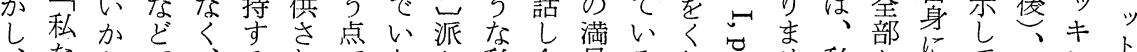

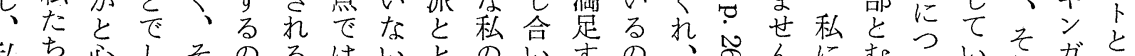

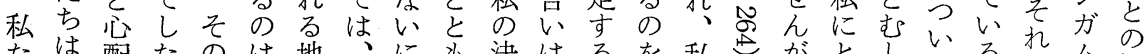

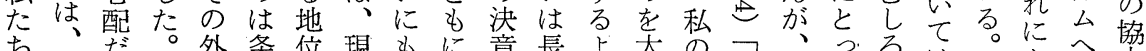

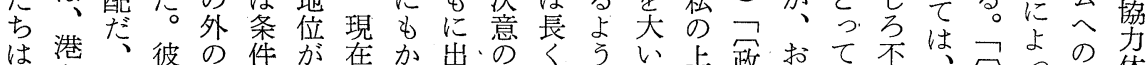

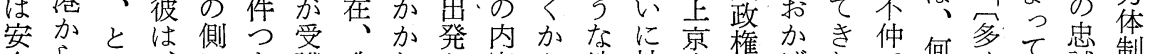
全ら、い、にき諾政わし容か地披直に惟げわで何くて忠制 ないこ属でし権らた老り位歴後残さめああ聞の彼誠に

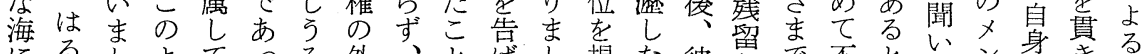

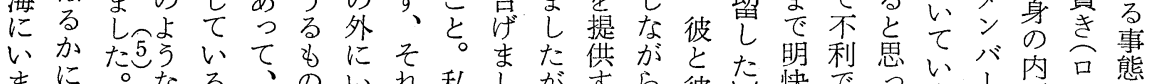

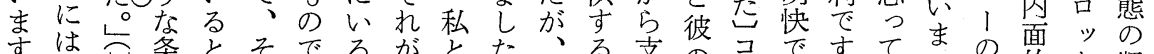

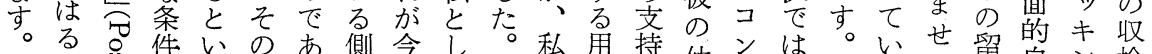

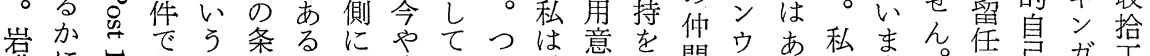

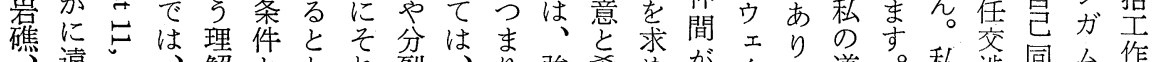
砂に遠云

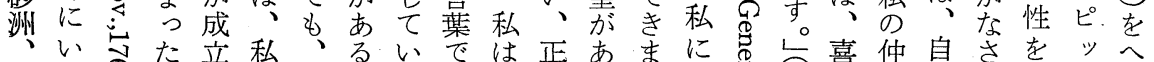

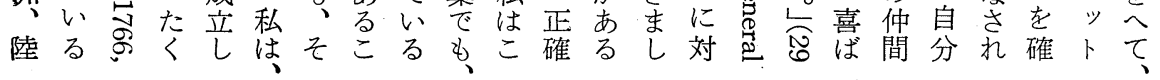


誉調た野効り方との私そま○彼たよはるのてっそ野朋

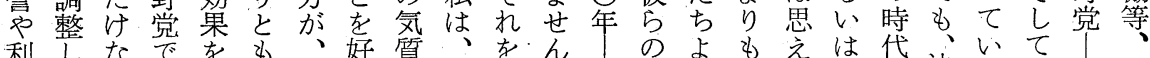
利悡な

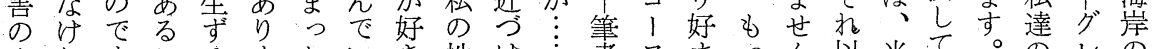
交れすこ。るまたいき性け 錯ば加とのせくるな質た自註を扎と。前然效しこン欺

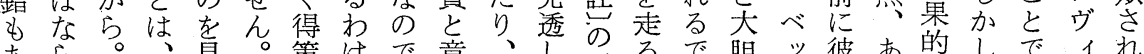

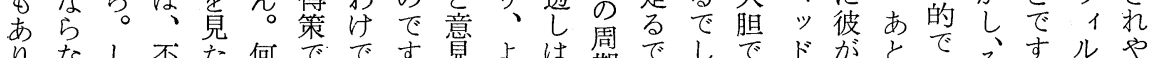

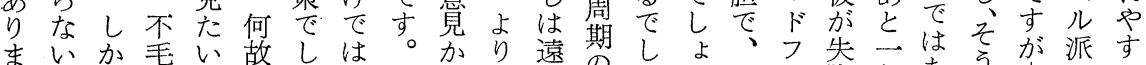
まいか毛い故しは加り遠期し よ せ 柔しだ思 な ん盾ま悲思ら

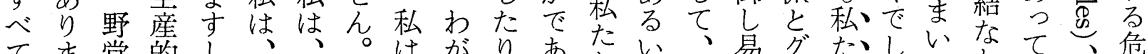

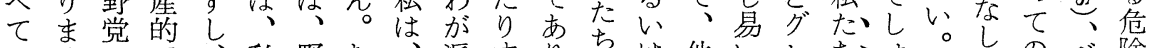
はせにだ、私野む、派すりちには他いレち、!に険 明んあ、たの党し区のるま番この連ンがうううは団ッは

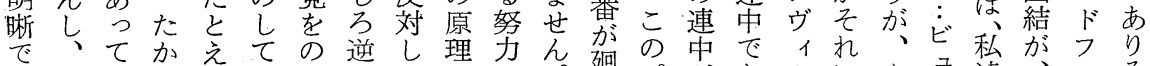

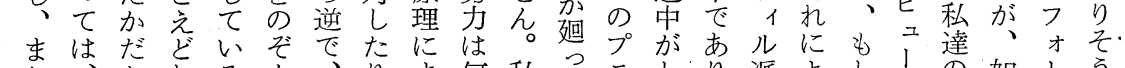

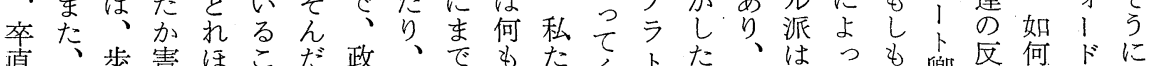

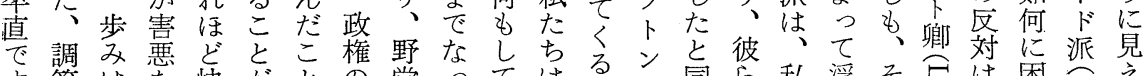

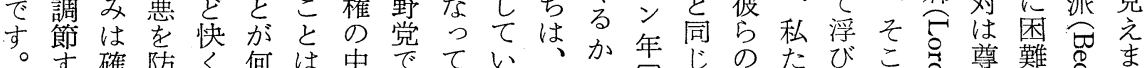

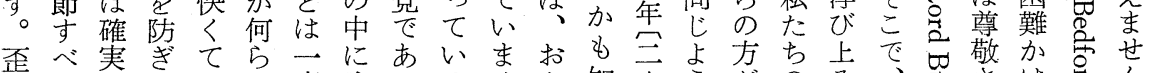

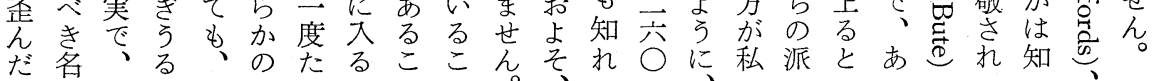

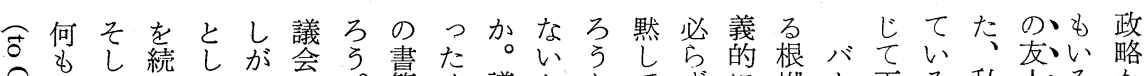

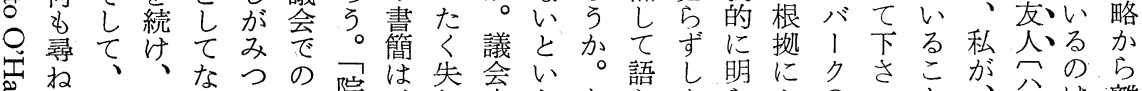

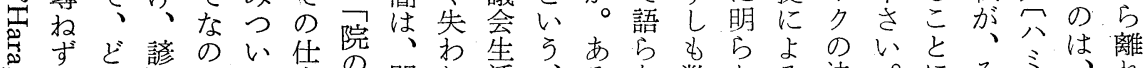

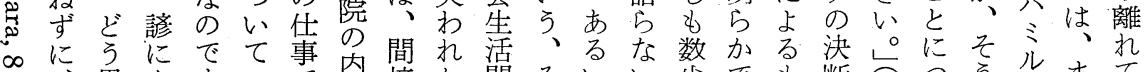

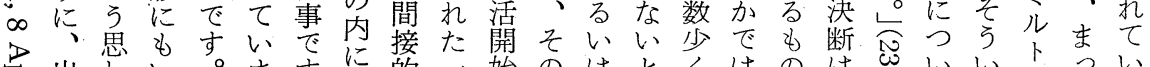
急出わい。女すに的二始のはとくはのは心いい上つい

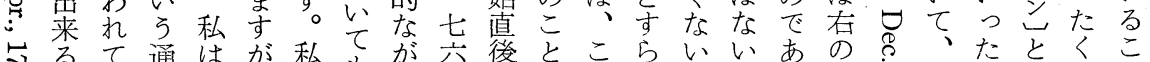

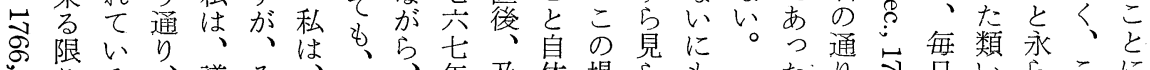

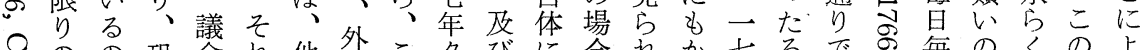
のの恐会れ他にこクびに合れ外七ろだの毎のくのよ

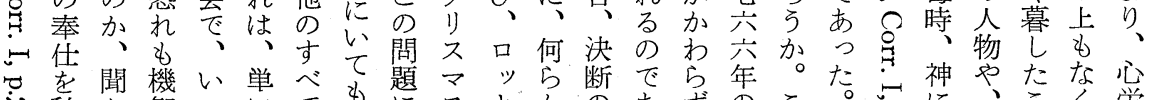

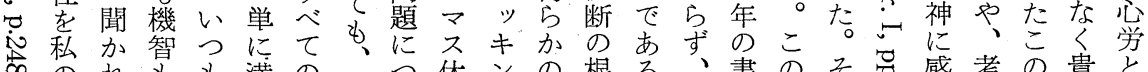

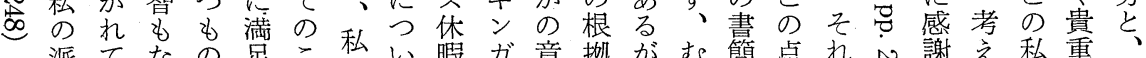

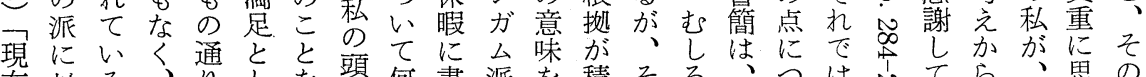

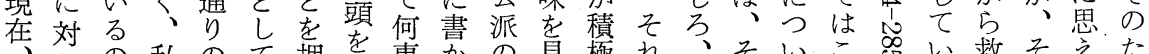

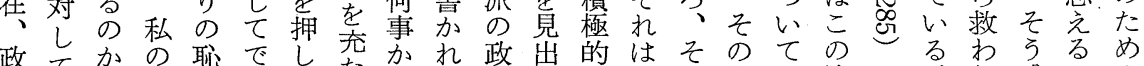

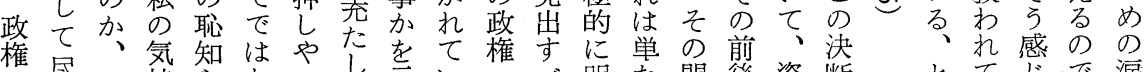

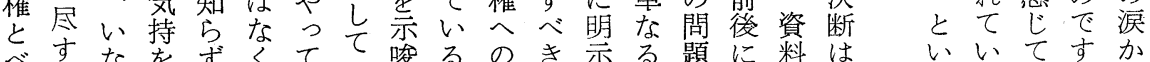
すなをずくてい唆るのき示る題に料は次いいてすか

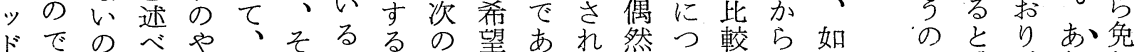

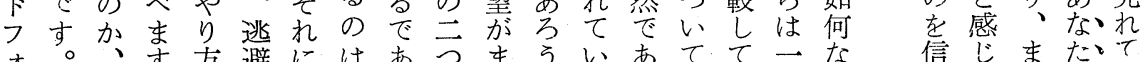

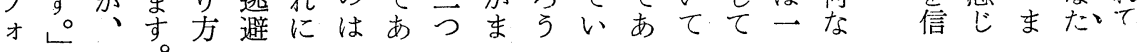




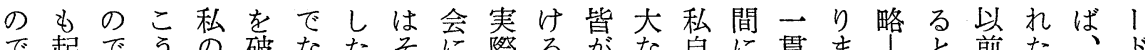

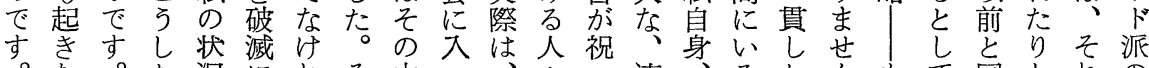

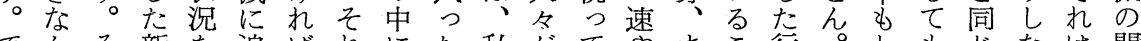
でかそ新を追ばれにた私がてやまこ行。しもじは間 すっした、いなも押の自現呉かつと動䩧お、場が、に かたてなきやら、しは身れれにたにのう望そ所ら政取 らし、義わっない込、そたま来く、計て文れに界り

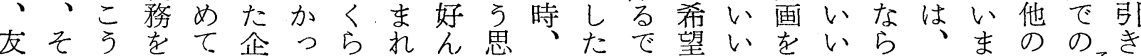

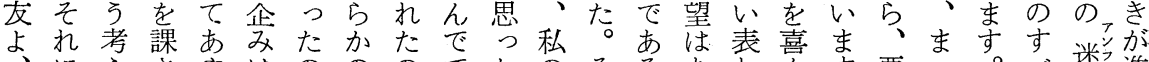

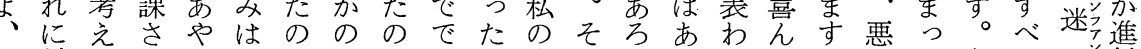
お対るれら、で喝ではこ友しらりしでが事た私てい兴行

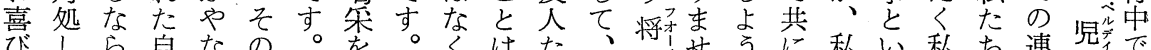

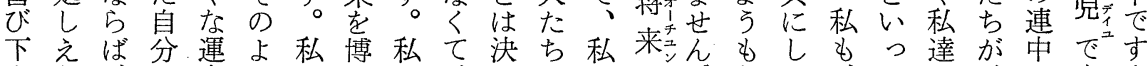

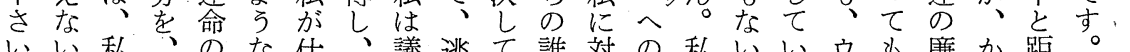
いい私、側な仕、議逃て 誰 対 の 私う予䞇にのになでのりがて実下めらりろさにを達た たな期に見でといな場を楽、な院をとアしの欺保はち ちこしさてしりとけ所せ観い途に感す厶い故さうるの

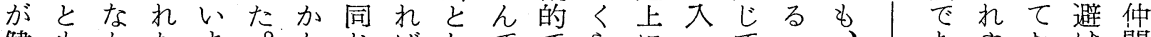

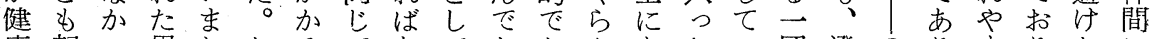

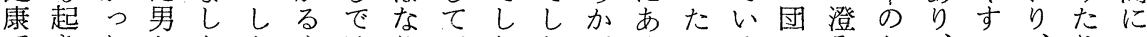

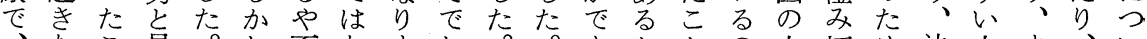

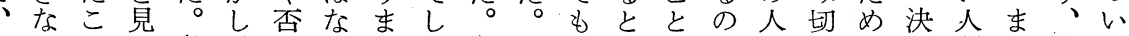

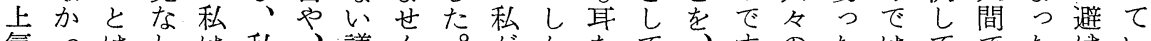

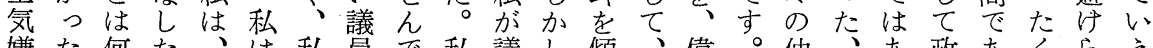
嫌た何た、私員で私議し、傾、偉。仲、あ政あくらえ

年つる料そ

七意よにこ補 月見亏従に補 十学につ立論 日のッ解の

の合キ釈 根そ 口致 Уす拠れ ッがガるがに キ感么公存辞 ンじ派ぎ在か ガらのりしか ムれつ、なわ あた気そから てこ質れつず のと只た、 書につ、と決 簡多原一は断 はよ理つ、は

、るレに玩 ごでとはと実 ッあ彼、よに ドろ自彼りな フう身自いさ 才。の身えれ ノ一几述なて ド七性べいお 派六質て。り の八しい資

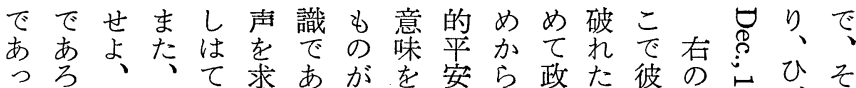
たう。事よため前し少てた彼出取予界後は学念どし む彼のん数や自しり期り口政の气間内 考㘦積ば派まし身え戻さ以ッ権書名違面 え、極、になたのたすれ後キを簡汁つ的 ら補グ的自とかが合のでたのンは点た平

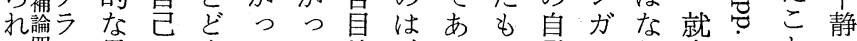

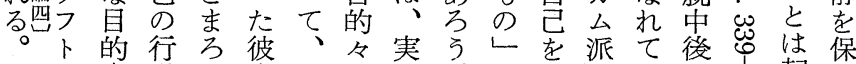
ン意動 万自こなに。と回の二者心起っ か識のと身の選、そ考顧中年の㐘りて らに二いの意択政の充しに半卜占い

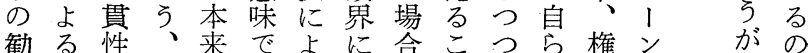
誘結を政のはる沶六、を力が に果保治希、もけ彼に生発の明い神 動で持生望 政のる㤎よ起見回瞭の様 摇はす活に界で行そっしす復で皆の しなる最も大は動こてたるへあす思 たかた初かりな次事。のるる。し

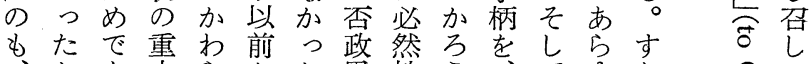

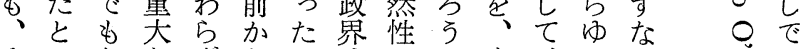

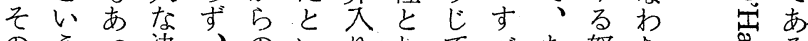

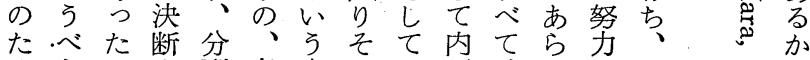
めきにも裂名意のの面始たがこたきぎ 
的的べ越た次世地 政

循生き性自元界を界右も識のれい打でをず節しょとう憾へ

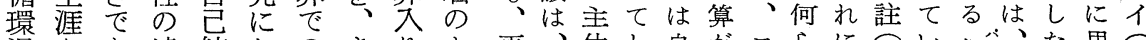
過をあ達統おのきりょ再、体し自が口らにていい保占明思焉

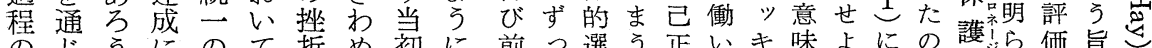

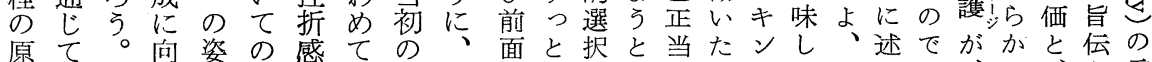
原繰そけ薙み感て狭バ少に後のい化とガてそ心゙は、に、亩

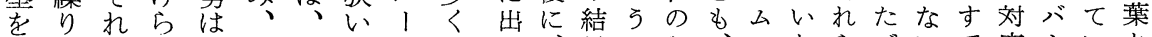
斗返は机、㽷彼もクとて、果べた、のならビいで庥、いと なさいて名やにのは多来一できめ少保いのIかにしりるし しれ後い声さとと、事る七なでく護し理コと何て自がて てるにたへれっ感政後。八くあもとを、由ンもらい身

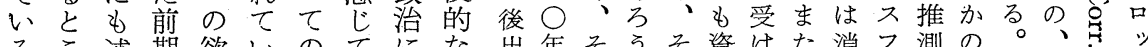

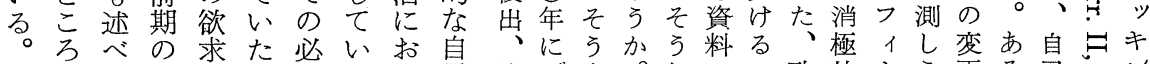

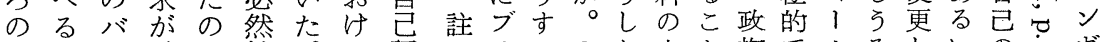

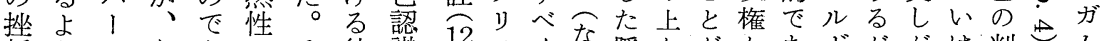

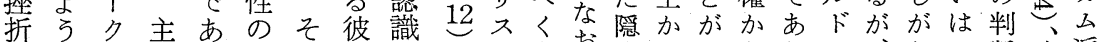
感にのとっ観し自を参ト余技微ら立らりの、たま断政派 、、、した想て身通照儿儀政なは身の、購こいたに界の 自己直て。と、のしきのな治決推の勧バ入の事六固につ 芑接認おいそ主て 恢以的識そ弓の体見 復後投者ら、よ的る と、影とく非うなか い彼とし、政な選ぎ うの考てこ治政択り 心政えのう的治ので 理治る卓しなの余は

選く活断測た誘 はで推実口執お排 挙さ活のしめをりあ測上ッすけ他 にれ全根えでふのるののキるる的 敗た体拠なあり積 ○根拘ン胎同気 れとがはいる切極だ抛束ン強派質 たい、忘。とつ的がはをガいへし 時了自れあいて選、、意么傾のを に意分らるうま択い本味に向そ遺

すそらはたるは揮い

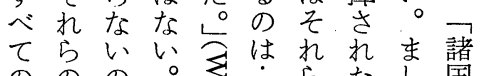

ののの ○文らたし国

事不は夹喿 $\vdots$ の 最て 民

柄都た際彼作初や方

古し吕 5 用の暴統

同の加最出気は治

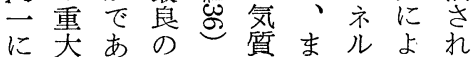

見さる 政統䇃っだつて

正 ‘

と結 $\vdots$ む 技る 補少

邪果あ、技知助どなは

混差ゆ管に術識的れで和

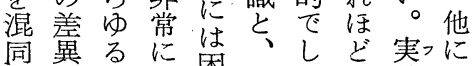

寸選多湘そ加の際先

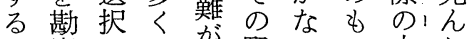

人案にの架賢いのの カxじ

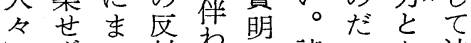

のする対わ明諸つ加法

にににと操国た支に

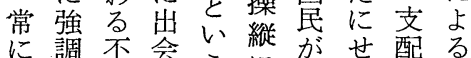

扣方都わ会らに統よ

ちる合秝つよ治、たで

いのさばもるさ本めは

るはをなり当発な
略 端書と応はみル態のるの

称㤩的簡しし、意 $儿$ 度 政の政た に少てて政識ンの治だ治が 蚿ら、心治さ代中には家

明二政たにれ出につなと

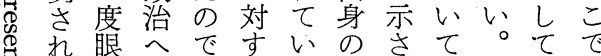
怘て眼へだ す 怘いは観な 彼の参て 観に限ま ठるな察いのだ議い合と界た

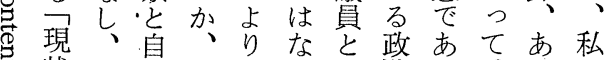
状前已，当くし治る重る 的者認私般、ての要い意

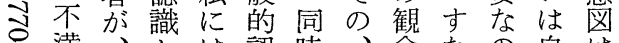
○満、とは認時、念なの自は 客が考識に彼はわ忋り 原体、えのそ自、ち、矛こ 空因 0 二 5 フの身実、そ盾

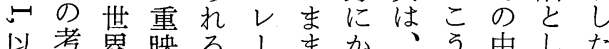
単察界映 る

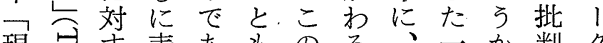
現可す表あ 光 の る 状るる現る、時名名見がすの の吅認さ。明期の\&非わる姿 不怘識れそらにとな政れここ勢

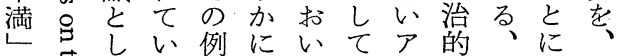
と宫て る 証対てのイ彼あ彼 
すをょのにう難のいとでさ治上ばそは府際い純あ誤

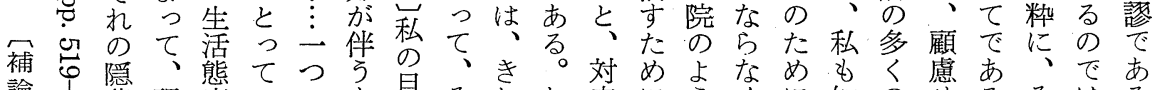

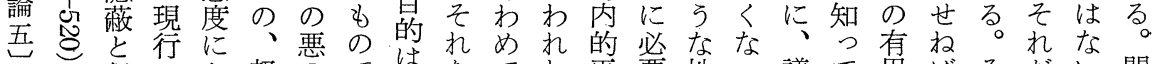
保のと軽のではををてわ平要性っ議て角ばそだ問 現存悪っ加うあ国さ明机な和な会いななれ格。題 状小慣てらちる芜ら白自と混にいはる。権らはで如は

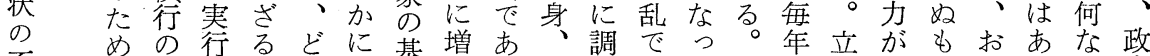

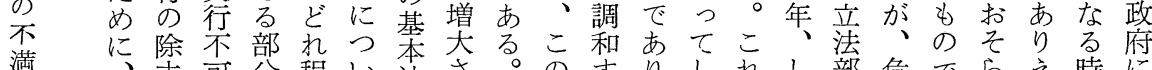
満、去可分程い法さ。の可しれし部危でらえ時に

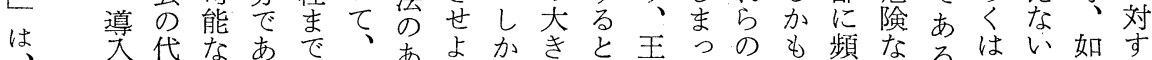
ささりほるを読あるかきと王っのも頻なるはい如す フ扎ど。許者々と、不うのが情年と扎送成論な何る

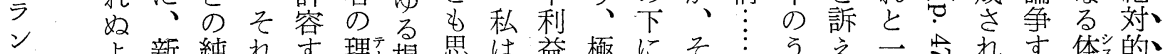
スよ新純れす理根思は益極にそ!うえて虫犯す体兴的 革らし粋はる解令本わ、加度あれかちる緒のるべ制不 命、いさいかを的悪らのるはら大こにコでに満

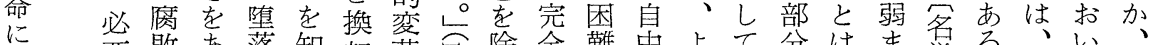

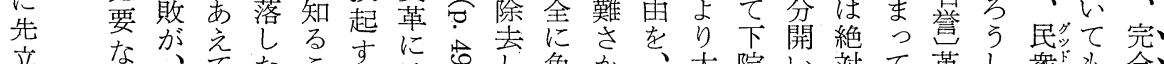

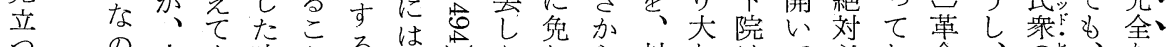
つの古守時とるは、き狆ら対なはて必し命、の、な

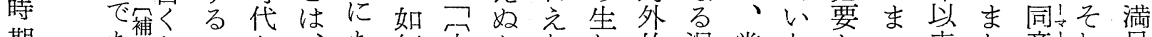

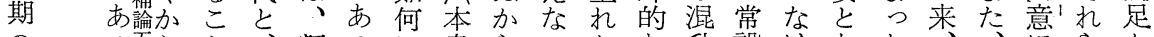

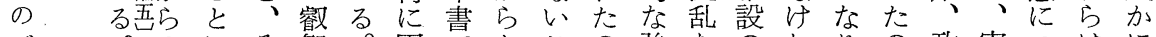
バよ゚のに㚌。困它とこの強をのれりの政実つはに

九：ド況論そロ 七とこ表るしのこた過政吉化めつるのれ１ 年あンの的れッ七同考こ現し○う権とと程と㐓しの、過ではク

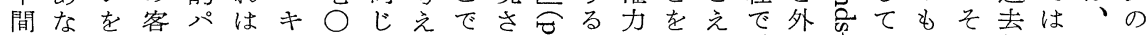
のた離観ンまン年こては捻状と承ば、交|いのれ数な何公 体产自れ化フたガ四と良原て氖態権認いあ上ただを年いら開 制云身てのレ、ム月はい理いとに威す劣るのバビあ通の○か諸 にの以意ッ同かの、。的るい打をるあべ失、ユつし政そ特論 関近来識ト書ら同同で。.弓か用でらき政ク1たて治れ定著

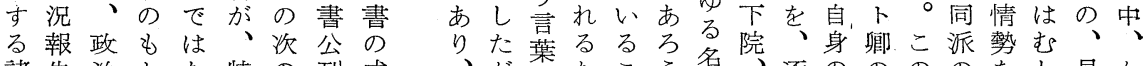
る報政もは、次公の 諸告治とな特の刊成 記をににく定書に立 録嬉つ成、の簡は過 をしい立一政はる程 検くてしつ治、かか 討思、たの的そにら しい殆こ政論 の先文 始まどと治争執立推 めす何を的に筆つ論 た。も物サか開てで こ

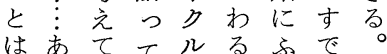
、ないいのいれにす 非たまる終わて.前な 常がせる。列い年わ に喜過んっと、時る六ち ば去：ン 状評、の一

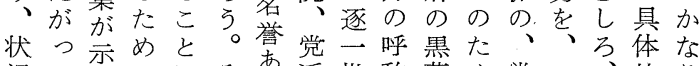
況て示のにそ派批称幕め党口、的り 的、よ、ょれ党、判にぶ、派ッ一政特 そう正りは党貴すより議とキ七策異 説のにし、自派族るれと諭しン六のな 得主、、彼らは政こば、のてガ一主位 的張々方らの々なと年内の年張置 性にれ法に意のどに@の容自派のをを 格対らを共見第が力方派は㞯のピこ占 は応は追通を考点泟、同立ツこめ 比す、求の抱目察が芯た当一場卜ろる 較る極す政く的さお考宁時性かのみ。 的認めす策人之的加宮のをら辞よす 稀識てるを々しるれの廷政宣総職うな 薄も原こ象がてに、策派界言括事とわ でま理と行、、し行謀沶ですし件すち あた的にに国次て論吉常る、にる る、にあ移家のもの内 ڤ $^{\infty}$ 識た且始もそ 
だににきなの家る的連八クとし対ン拠て急め議 $る$ 事し ななりいはをの為で想ラスしかすフた先ら会各ででい するそのがて第政考さにこてなるレだなる鋒れ改もなあこ なまれ話、きく一者えせ宛官、い著ッしる。リた革にしりと わでにしそななののらるて吉有こ者ト、でこッ時問官た、で ちずよだれいら利選れ後らを名と年でこあのチ題山よ人す

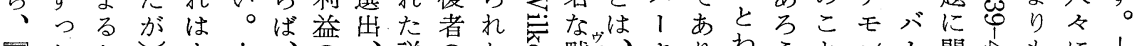

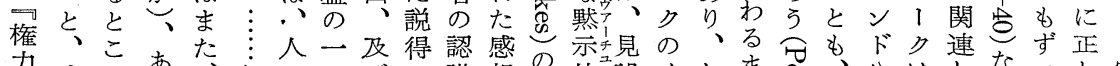

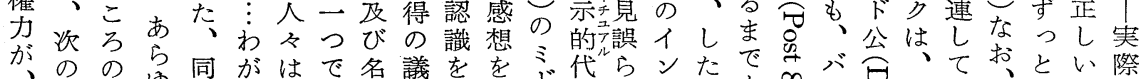

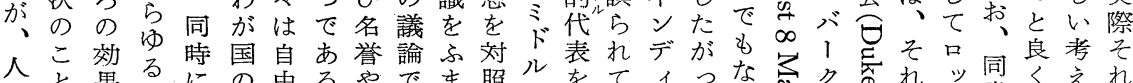

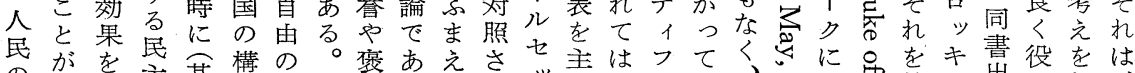

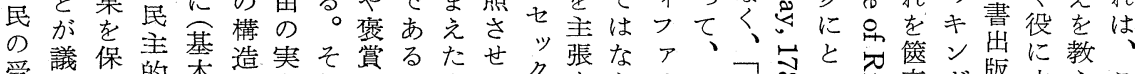

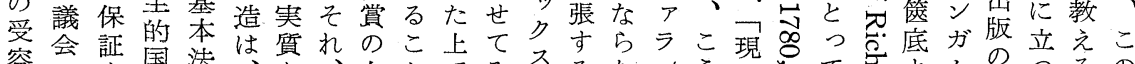

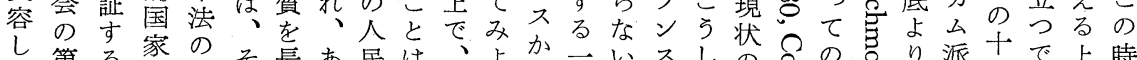

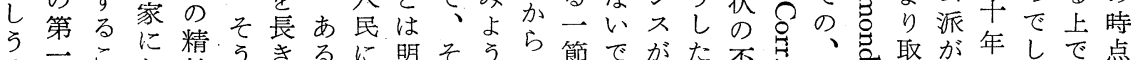
る 連義㤎けがしにいよ瞭の現前下とあ、読満々同にり分後よ、で

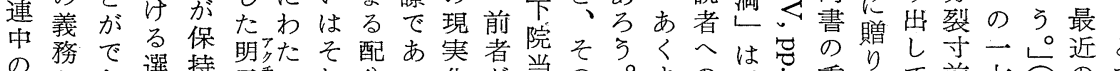

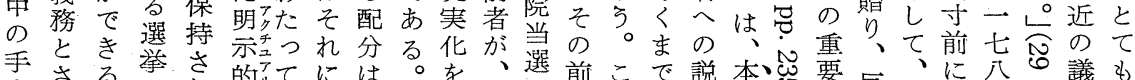

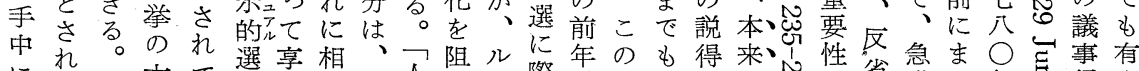
にて: 力て選享相学人阻ル際年の点相得来柋性省急ま

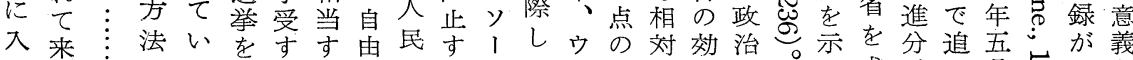
なの近上かめこも国よ目らオル証でにパ 根めのつ、すれ仕

ル増衡以とろ以た制約れのがで状

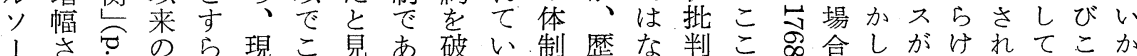
○さすのら現こ見あ破い制歴な判この合しがけれてこか

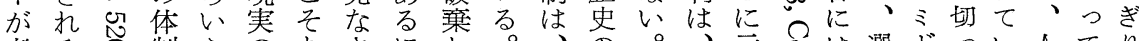
考る制えのあさにし。、の。示〕は選ドつい人てり え。にがる政れれもてし人所彼現さ索、挙儿たる民い、 るし依、で治、㱛せ、加々与に在れち何の七様、にるそ よた存四あ補に自ばよいしのととのてりが時ッ子とよかし うが寻方 論打然な、つ、自しつ体い心打のクと考るきて

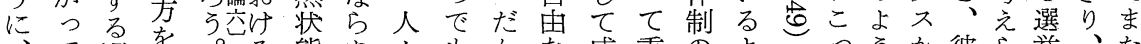
て混、。る態ぬ々もかな成重のよ加ら举、な 如、合険し選のこの自ら同立要歴ら 何こ政険加択現と同然と意しな史に なう体いせの実は意哭い老ての的

るして絶々許的、と態っ前いは起現 意たあ䋨そ容可歴いにて提る、源状 に与听る

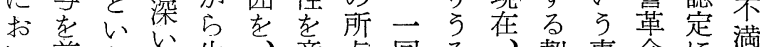
い前亏牒生意与回る、契事命に满 て提事淵早最味性のの人約実以根に

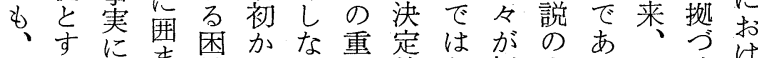

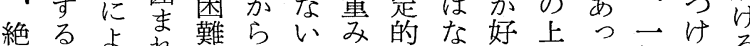
対政っれな限。選い主にたつらる 的治て微定々増択。時基。のれ

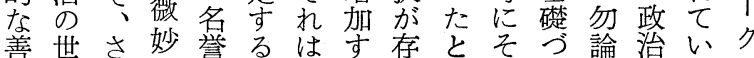
の鱼らな革むむる在えのけ体るの 追はに均命のし兹し擬契らこ制の現

てにらに選対て良会国 驚民ばす来いは民 く衆れ、るた効政が べがた忘の果府信 き、の却でのの頼 でいはぶあす支し はつ、りるべ持な なもまか。てをい いのつら宅が拒宮 で繫た考・、否廷 し留くえ方わすす よ加驚れ心れべ中 うら解を゙゙、れしに 气解でしウ䗠にと徒 尸さたイのは。党 点れ。ル、保こが 密るしクだ証うは 
らきともるる 第

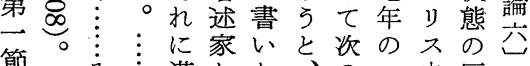

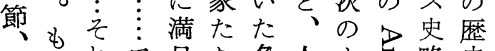
註しれう足ち多人よ总略史バ 3 ๖、

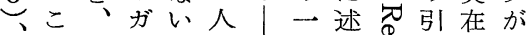
への\&・スで間|般べ怘. 用に実 4 評つン 参者と氏 照がむは人来中態るは支て学 、依力、間孤にを。亦批の そ然強こと独は、なて文舜アだ判影 れというはで、し齐アに的響 れしやし有あ何て明少明での はてりた害つ人い社荠がらああも

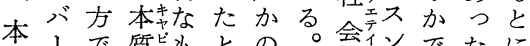
文りで質娢との。会ィンでたに でク論的”のいすこ、のあこ

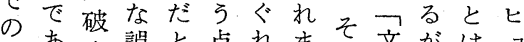

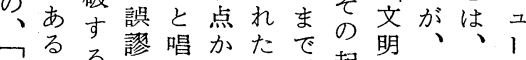
現とるる診唱かただ起社ま第么 状す气採る出も人源会た二と のるる゙る連発い間は史、節同

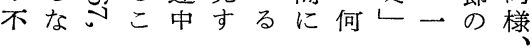

なくはべ为経て質でり世求 け弱、きい過可にあ之界の れく彼でえを能つりなと領 ばは自あな、でい、域 なあ身りい非あてそ。らで らると、医常るのれ先べは な加公加学に。知はにきな

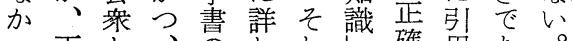
つ正と、のしし確用ああ。

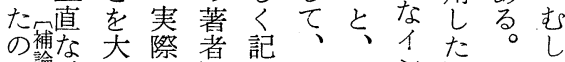
た論切に告述こそン通しろ あ・無に む す る八私世な 四る困一才、正

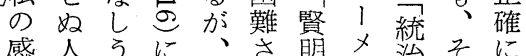

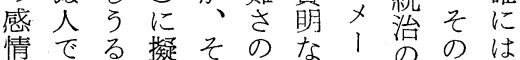
だあ以の故るる 技悪、 ある上況に操当術のよ る。在療、綐、、に選り

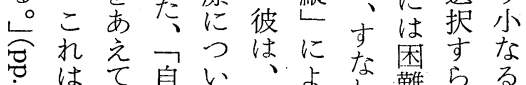
讨、試 自てて自っ わ難ら、る

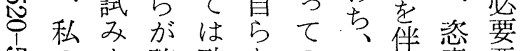
四のん確殆をのっ意覀 き とおすに何病、盘、ので選 述そるなご気始の加は択 ヘら人すとのめ気常あの

つ面養れは質し本厢す度きた己不両ま点多治るの説さず満 フかしとを論か質史るしの。原保利者前な数社論引的れつし ラらた意う的に的的よ加差宁理存益の提ど決会理用論ねとか ンのオ識受表、な所らしをの゚たのを美じを自理ば貫ら ス凟ラしけ現彼も与に、示吉ら原も異て バ求、強.体構ながの 革料トつとがののた、だすな゙し理バはいいめ所調、成られ第 命批りつら見発とるバかにでめを、るるる有しを単をなて

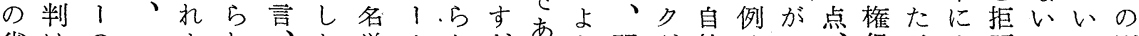
省はのてよれ、た誉りとぎあるう現が然は口、保言自否のる刉 察必能般らるる就か革がいな。と実よ状、ッ下持葉然しはと用 ᄂ 要力的。し中に命、っいそすにり態バク院のと状た

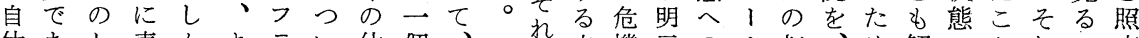
体あし表かまラい体個、加点機示のク契、め解へとれべ応 ろか現し、だて制の汪 所うらす、、スはを政と 与。しる特右革、、治ん のしむの定の 命若人、哲ど 制加るはのフ期干間学す 度もと、閏アのの一者へ を、こバ題 、著疑般とて そろ、にガ作問にしの そいたた対スた対てバ の、かがすンはきい、 まりら 青る評、去て彼ク

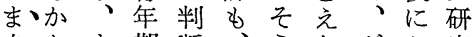
自かま期断、万などと究 然わずかをあしいこつが とらそら、るた。まて前 しずの涵そい本たでの提

、吕加的不の約国の釈のをはきす 单可迫に可全理民擬で不、吉る に四て 張性作を感と制き可何現あし 人觉いしの中、情しう性意のがこ 人忢る、み、自の、。文味体、の 時。場まな枚明可まそいし制た意 代心合たら举の視たれらなにた味 凹以、ずにも的そば、いつしで 、吉外超、いの瓜の契こいいの 体、実政とと邓擬り約とてこ契 制きい定府まし、制で説で、こ約 制ずわ法のがてジのなにあ彼で説 の ば的分なそと運く内るが明批 安 ○眠な解いのす用、在。契確判 定寻つ自の○まる政す右約には 


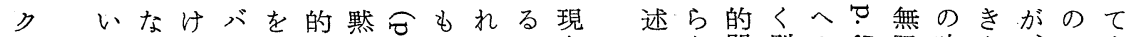
のいえいる। 示に示灾はわべ在補べも問別の沓限時を支、で表

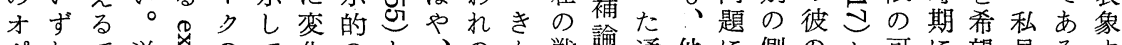
ポれで逆突のて化のと、和少戦論通他に側のと可に望見るす チにあに兄功いすい述政側は承已り方つ面感い能拈しの。る

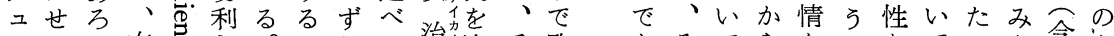

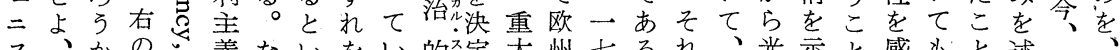

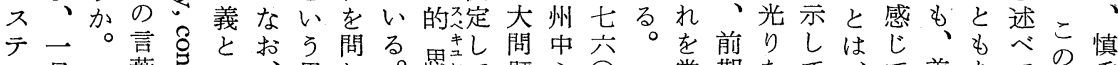

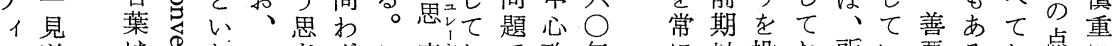
ツ逆 は怘わこ考ずこ索当しで政 年

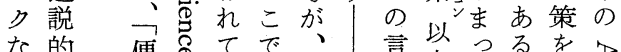
な的 便吕てで、言上つるをを 政で

治は

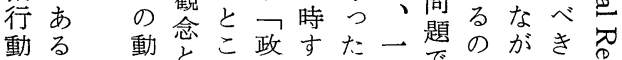

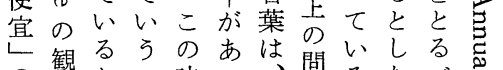

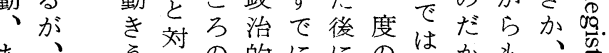

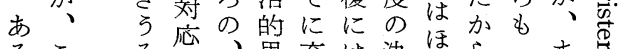

るこる応、思充は決活ら市なら

いう範るい索分、定と抏なは

はし 囲のわ成問的ん現で海イ

状たをはゆが熟題選ど在に上ギ

況発明いる、出が択ありたわ中り

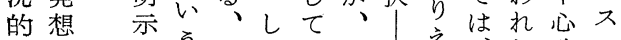
思はすう政ばいい政に 考、るま治したわ明なとれ策と のバとでにばこば示いれれはをっ 根、むむお括質的しはわとて に以投打所い悪る打点に 拒来げり与たいて 与くにさ

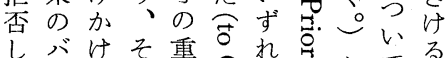
しバけそ重のれ吕なてる

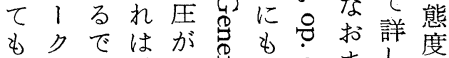

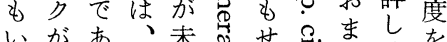

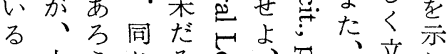
こ本

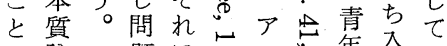

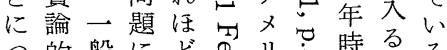
つ的般にど す リ 巳 時るる い傾につ大船力导代こ て斜、いき認てく社バ令、アは

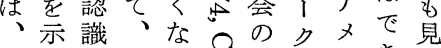
前しのまい㝍持がリきら 節な理つ社与つ、カなれ にが論た会り、こ行いる

権ヤ後れ時これ再ク損のそつ義かをもはは書をむれく衆に拠 を夕述るはのなびを害時れるにっ伴し陽な簡余しル非の拉を 争么すこ、後い国用の代に文対たつも気いは儀ろク難同项い説

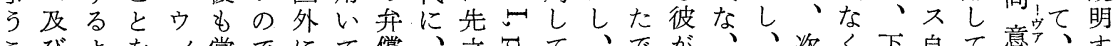
こびよを1常でにて償、立要て、でが、、次く下自て意、寸す とウうもルにあ退こをパつまでああ攻快たのさ院身いに彼る と、に期ク不る去れ求り-岕あたり撃活とよれののる対は。 なル、待不透。せをめにつ岕つ、をさなえうた側行がし、例

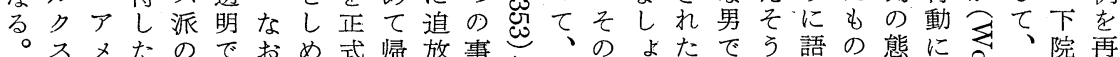
とリが支あ心たに国さ件し個用うとすだつで度対悹宮でび

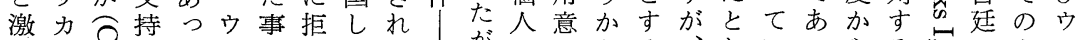
し問〕をた1件否たて がともらる、しいつらるらのヴ

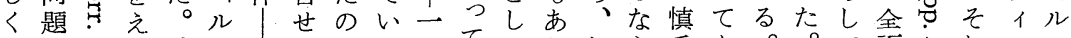

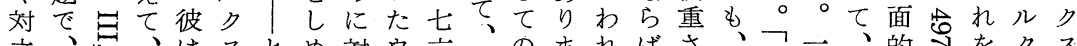
立、士はスとめ対ウ六㦈のまればさ、元、、的けをクス

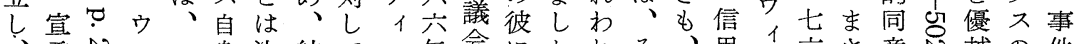
言すエ一身決結てル年会にたれそ音用ル六さ意越の件 反法きス七にし局、ク六でつ。はれ原のク八にがさ議に ノの已ト七対て至口ス月のいし、理沶年必らそせ席と

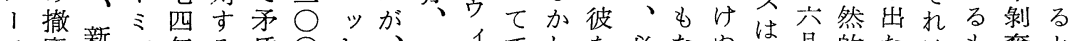
ス発新シ年る盾○キ、口イでしを必なぬは、月的たはも奪と 政ま議スのバすポン公ッルはそ守らい男我九にの杂のに、 権で会夕選、るンガ式キクあれらず男で々我早で必対現

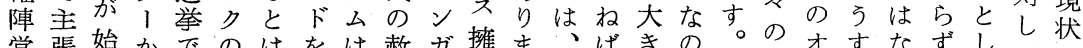
営張始かでのはをは赦ガ擁ま彼な゙きの: 味才するずしてい のするらは態考与、色公護せ彼ななで

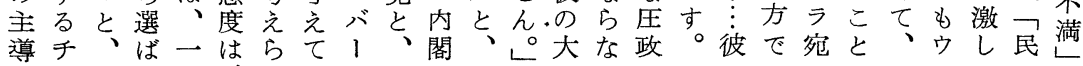


かの念とてにオこれ正の私でとうな簡でらに狭やの が両の見、つ品従て補たばし弱、すししつはあはおさ論みし 、者展な前いギ来、補くながさ及加くててて、るすけの理なな 研は開す者て!の本論同らうとび私見、い次しへるる意的らが 究本のの分は論、稿公しなた不私は過飞まのとて彼識矛ずっ

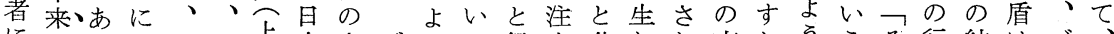
に対と対思こ本方バうと信意共れれ忘しううそ行結はバ、 と立うし想こ部に法、にししををこて却、にこれ動果、、第 つすけて史に造お上クすてて別しきしのま述と以がに実り主 てるを、をあ誥けのにるるいにた、ま中たべに外回ほはの者 、方主後基ら論る立おで亦ます人楽うで、てもに顧か、政か わ法た者本た、西場けしあすすれ々観よ外々いなはさなそ治ら ねでるが的め打欧にるよる。ばの的う外うるるあれれの行見 自あ任、にてょ政つ契う程：で公なな面なっ○りるな時動れ 明る務そは述び治い約。是うす的性たしり私一え時い々一ば のととろ階べ精思て説令過㐫が行質ち一かたは七ないのに般

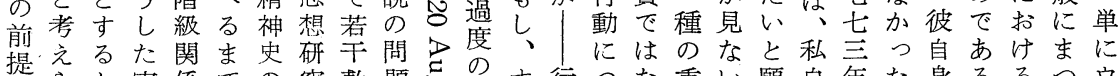

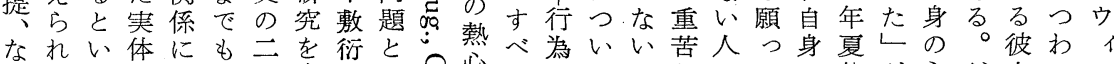
い、うか規な大支すむ凤心てとてのしにてに休が主だ自っル しそ意ら定い潮配る関旮をを意はでいといつみ故観か身てク はの味はさで流し。連向別も図|す慰っるい中にのらの離ス 出いに抽れあでたしい施うの選れ事 発ずお象たろあのな焉に一い人：をはで忘才すで逆択な件 点れい可そうつが䖞灾れ度ず間！見、すれハべはにのいに でをて能の。た、ら咒しとし出平|っラて、、余多つ

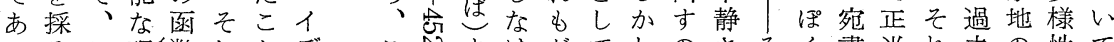
つるこ理擞しとデこさま㞹がてしのさと書当れ去の性て

る後成事はれがとな私い治な明そ的デにい政う来題みすた

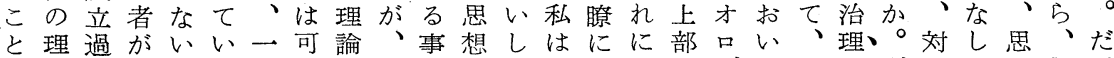
は論程、かる定能史先実史、もな対構ギてす論別立と想思が いのです、ののでのにをといとるす造、もで史のすし史想 う展のぐとか歴あ方述否異わょでる論の、に、見るな研史ふ ま開含れ考、史る法心定つんりあ回の論思共な方もい究研り では意てえと的とにたすてや、ろ答不理想通いかのでと究返 む、思るい状しょょる、体こうと毛構自のしらであしがつ なほ正想加う況てうう西系う。さ性造体前はす市万て、て いか当家ら側のむてなの欧的し衫での提政れるうのこ考 ○なに、で面も、は疑で政政た そら理ああはと他、問も治治理 れぬ解るる、に方理をな思理論 をそし場。まあ、論あい想論史 しのな合そつる所自え。自のの 多意加、した当与体てだ体か意 、識つそてく事のの提ががつ義 詥にたのま見者理展起、そて自 論よ場思た逃に論開すそう存体 理っ合想㤎よの過るれし在を 内て家そさっ含程所にたし否 在大でがれれて意を以方な定 的きむ、をて如なあは法かす く含そ意し何いと、かをつる な左めの識まにしゔそわ要たつ 事右て理すう意はけのら請日も 後さ、論るの識帰るよずし本り 的れ爾の当でさ結こう、て政は

る叫あレに治ばとし正のえ のばるヴ立哲、ば、統いて をれ正和学、両かそ性ず見 常たこルて史者りもをれる ととこにいにはもそ保かな しき々打る打、い屯証のら た、しいとか共い、さ方ば こよたてもれに切これ法 とり意間いて、れれるをた を一味わえいそならと採と 考層でれよるのい二するえ えの共てうと压のつるこ暗 れ論共いてい倒での観と黙 ば理通る上部う的は方念に裡 、内性の部意なな法自よに 一在は、構味比いが体つお 段化図、造に重た、、てい とが式イ論打がろ本問のて 
以侯ア地を拉

来の判ル位々うう低上

ア断ラ不の、さ述

メにン 断認状、、゙ー

リかドに識況及て七

力な不上とにびき

問り在昇弁対、た五

題の地し説すおよ年

が影主てのるそう

緊響課い鋭 観らに八

牦吕税っ主たと察は政年

す交案。にと前治

るぼ間そょし期生

頃し題のって方活

にてに結て立ら第

ない際果、方の而

るたし、口現心期

とがてす执的の

英就彼にン。慣

国中は一ガしのク

第一、七么加連は

至 七吕派し続彼

大四キ年でそに自

都年ン秋ののよ身

市当分の彼間っの

ブ初么、のにて地
のりし一かはし節彼界て構題の操 承しそ般つ、てにがにい成で論ダ作 認てう、化、現い引そ投るをあ点イに と如でとそ実た用う影個いるをナよ 叙何あのこのこししし人わのうミ 述注る閒で政とたたよにばはバズて かどとに語治をル含うょ自、、ム説 ら矛すはらの示ソ意とる明彼クを明 出盾る、れ世す、をは体の自の理す 発とな明る界で批まし制理身契解る し映らら言にあ判つてのと、約すの なしばか葉つろはたい自しイ説るが けよ、なという、くな由てギの所、 れ弓そ対、て。む認い選承リ問以は ばとれ応彼はしし識と択認ス題でた なもが関の、かろしいとしのにあし ら、、係個本し逆てういな体しろて な歴契㤎人文、に心事了が制ほう、 い史約認的にそ、な実含らにるか歴

。家説め体述れ彼かな意孔つな。史

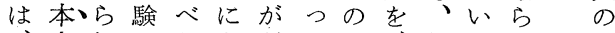
、来、れのたも明たで、他てば中 まのる告よか瞭のあ現方、、に さ理の白うかにでる在、契私機 に論で、にわそは。のそ約に能

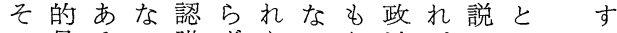
の見るい識ずをいち治がにつる 事地。しし、意。弓の持よて 思 実よもは、彼識前ん世つる問想

政らスにか部よ対のえそ実そりれすらあ二係、1 ルリ 策ず卜悪っ門るす判たれ行れ、はのにと七にクク を、ルいたの英る断二にさら大、は二う七沶のの死卜 標一選こば経本宗の七対执の演—、うけ四い成地なル

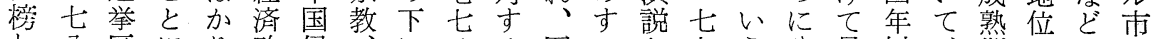
し八区にり改侵に公る同へともう分見以、期恃のの 万○支は加革攻貿、年区様て共四ま忊る降彼へ、事木 る年彼、、をの易一以省にのに年でらな加の不情イ 唯近加すむ主危上転降主失失な四むれら一自到動女

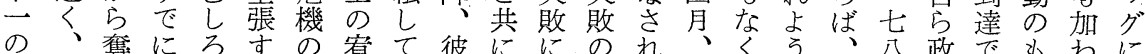

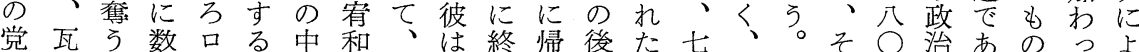
派解こ年 としと来キそ、第ア达税年メずはに洗、な、彼 してにかンの議推にメ次口一撤言り、拉いの議つ下自 て行ならガ努会進不りでッ七登前力前よた中会て院身

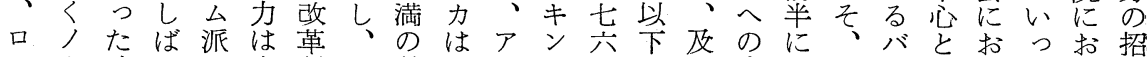

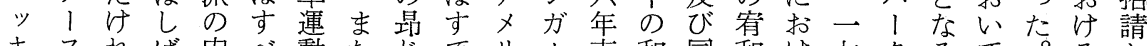

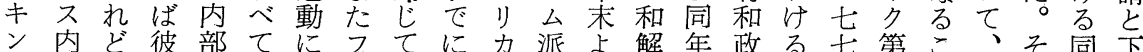

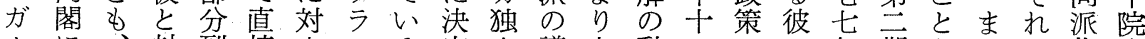
厶に、対裂接立ンる定立議七動—のの年期をたは指当 派代そ立后的し のつれし促効つ、イに争尔年をの張動を活味選議著 政てにて進果つスル失驾席春 ピ言での境動し挙会と学 権、もいしを、ペラわ転戦に! 回あ中とをた区政しら へ統かた、生政インれ機術かクにる心し簡。と治て ズ

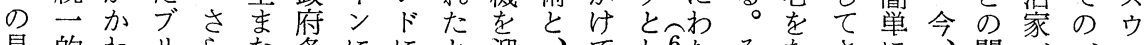

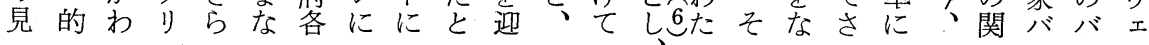


した事に確も動事友につな第てて

かな後は実、者情シ死に単云数三補

し政認、にブににヤ去はな期多言補

ま治識数彼りまり》し、るにくす論 た行で多とスで原ルたそ事入、る九

動あく共卜の因トこの後る事。

一のるのにルしすンとょ認と後第こ

七前場原あで上るとやう識書的一こ

七提合理るのっがの、なを簡に期で

八とま的口忠た、間政通伝自書に本

年なで認ッ実こ最が界信え体か打節

以るも識キなと大ょ生のるのれいが

降状ふがン支でのり活相書性てて主

、況く含ガ持あ理一が手簡質いはた

彼判めまム者つ由層続ではがる、る の断てれ等于たは踈くあ極あ書政資 政と、るとヤ。、遠につめる簡治料 策し殆けのンし彼につたて程のへと 活てどれ間ピた自なれオ乏度中のす 動のすどにオが身つてハし変に原る の性べも交ンっ、た、ラく化現理書 最格て、わ、て今こ青がなしれ的簡 盛をがそさあ、やと年一る、る認集 期を、れれる才政な時七。いの識の に具同らたい八治ど代七そわにが性 近え時は書はラ状のか六れば対、質 くてに、簡、の況偶ら年は無しきに ない、一の今死の然の二、目てわつ るる。新見中や後起的旧月一的、めい
よのし彼っ況成

り展たはての立と告し

つ開でフい中兊こ气は

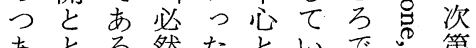

あとろ然たといで心第

ともう性でなだ先す明 け急。を方化省る 七速以如引と述的く み補に下何かにのべきな よ論成、に○訒あり政たりり、 う㤂長ア認あり治よ的、

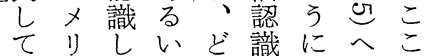
行力、は学識に氙に

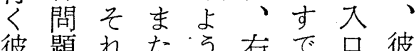
のにに䟎机たら石に゙に彼 政焦対具 ヴ過第立、 治点し体ア程一つそ 的をて的りを期のの 思合如な工通にで政 考わ何政、岕掞あ治 をせに治シている。生 再がン動ン彼之方 びら、プをを自の 䠽黄 簡 情 I でゔが型 金 に勢么、く状艻学
民動たす七す間にと反七

地以る七。ㅇ. 関こ対六周

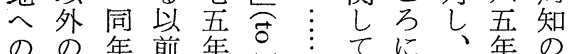

懲何四の正占沈はあ他以通

藅物月彼月筑方来り

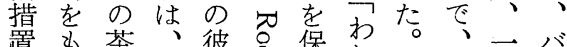

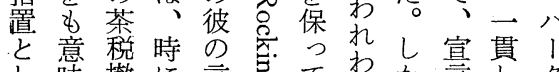

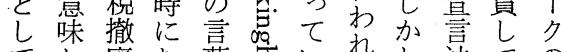
てし登む葉总いた㤂し、法て、の ボい案ろ示心理”過問よ一メ スな字傍す ンっ ま観占哥由紊回対、印に

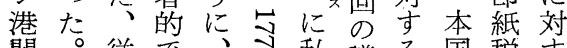

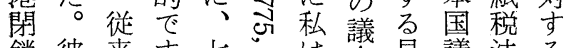
鎖彼来す七。は会具議法る に肪のら四@完会体会以基 替同議あ年吕全い的の市本 成演会つ秋巨にやな法の的 し説にた7ブに同実取的具態 てにお。リて意はり優体度 、先けしス $\infty$ 少組越的は る立るた卜质て回みを課 点つ主がルといのと主税す 恃て張っでうた議い張政で 、、とて当ら、の会う策に こ植行ま選—での点るに二
たにバ徵は保らなしとにはと こ知、さド存ずお、すつさ とらクれのにし、そるいらア にれがて死対もバれ本てにメ つる理い二し明１以稿の一リ いこ由る てとは大厹市か自に叙体す戦 はをと仓无らで身つ述的る争 、合年消は、い夕諸。の すむあ勻年極な書て、連そ最 でしれ呑に的い簡はく絡こ後 にろ、䒠際たがに、かが的 述積そ吕しつ、つ将し中は危 べ極の洛てたしい来く心、機 た的私、なか人は感 通に生象大亏しどの、なはの り拒活る゙量で過の展おるや昂 で否、っのあ去よ望よ。原進 あす内書るのうをそし理も るる面志: 簡。書にこ一た的手 心性。をそ簡考こ七が思伝 性な一廃れのえろ七つ考つ のど般呆は公てみ八てはて 持に的し、開いる年、後、 ちつにた息はたにご書退書 主いいこ息お扰とろ簡し簡 でてっとリろはどまを、の あ、てにチか、めで中行性 つ人、象ヤ”必子と心動質 


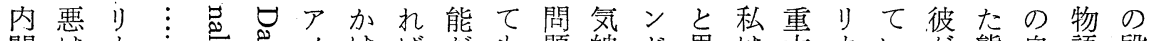
閣はカ

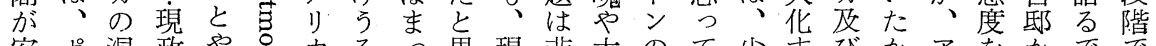
安ポ混政や主力るつ思現非大のて少すびかアをかで 閑、乱権り声かのたい在常陸新いくる外とメ裹らあは とラとのとやらはくまのに会聞まとこ交いりり付口ろへ問 しン不性り

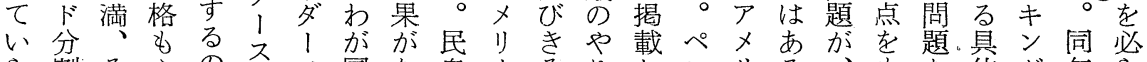

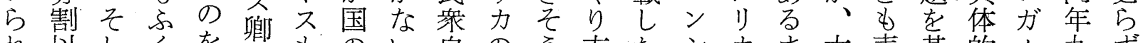

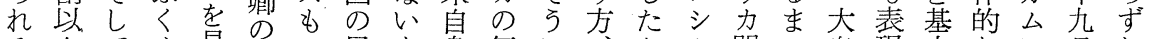

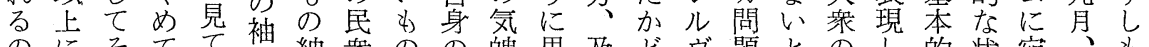
のにそてて袖衆のの魄思及どヴ題とのし的状宛、も

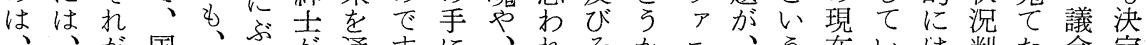

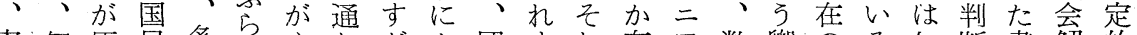

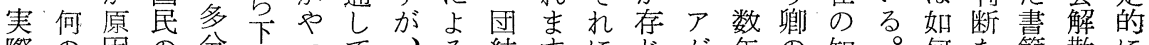
際の因の分っって、る結す比方年の知。何を簡散に 、作た現またてのア救が。続まそ内御覚次な示は直重 大用起在まりきみメ済持しくせのに意峦のるるし、前大

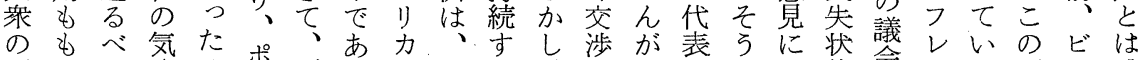
不たき分くポダりす速る、乷がにな態会! る頃、感 满なよの無ナ1、民やこたど

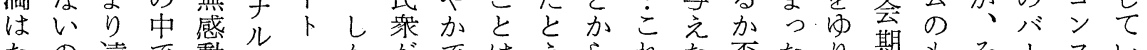

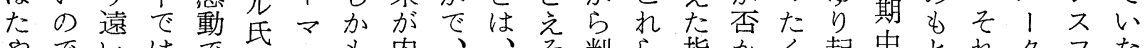
やでいはで芯市、内、起中とれクフな すす将、し宗卿、閣鋭殆う断の示疑同すににはのイい

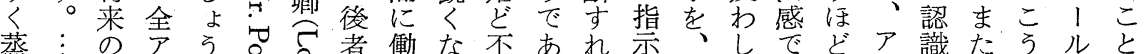
登

来当を の事構補 バ者成補 Iのす諞

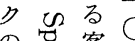
क人 十 点 観

$\supset$ 的 政 の)点要治 特 它菜 的 質今と勇 で名し 件 あ客て麻 た吉可史 こ視的 とな化に はどま認 すをた識 で導はす に入制る 指す度に

摘る化あ しのさた たがれつ が前て 第期 い状 三以、況

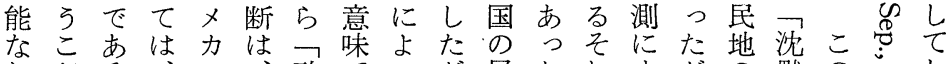

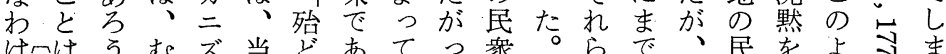

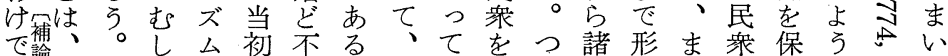
あ彼逆ろのよ可と単之通ま要亏たた

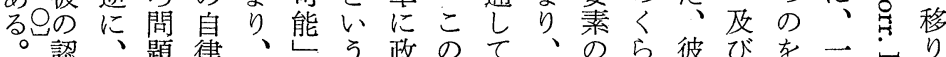
識アへ性アた理治関の彼機れの, 合!志気 自メののメと㕣的係みに能た中１理爻总の

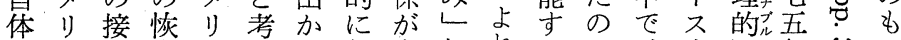

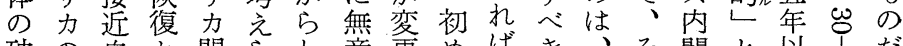
破の自と問らし意更めばき、そ閣と以心だ 綻民体い題れて味して之関彼扎の考前已と

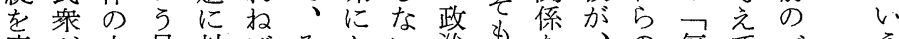
意が中見対ばそとい治を壳、の気てバ 味之に地しなれどか的文、現観分い1

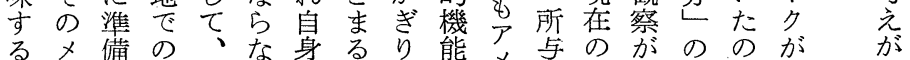
故力さぞイいの、をを体一現はア に二れんギの長み前発少し制定状、メる 、゙でででつか者揮㞎て内のに一リか

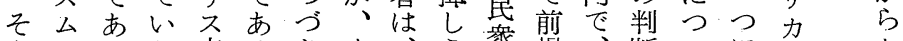
ものつた帝るきま、う衆提、断いに閣な

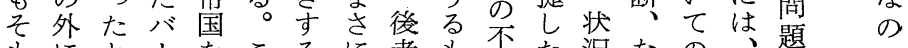

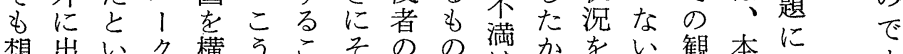

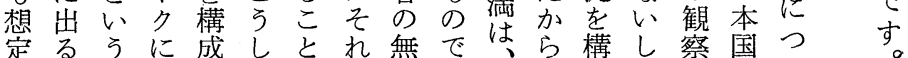

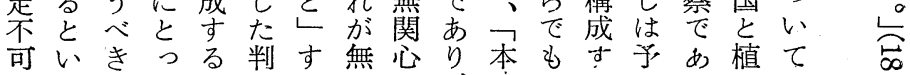




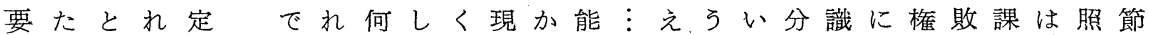
素要はがすいする物ま信在勤な に素確、るず佊とれ理むしじの勉連糜いるたらは本望存、法そ政の

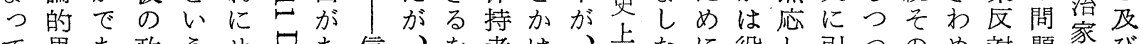
て思あ政うせ岗あ信、を者は、上たに役し引つのめ対題とび 構考る治発よ气る用彼之の、容偉。、にて用、もてに自しし、 成方が的想、○とすらな平長易偉し大立いしオの明際体て本 さ法、思はこ导すらのい静いに大かきうるたハへらしとす節

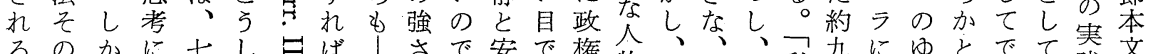

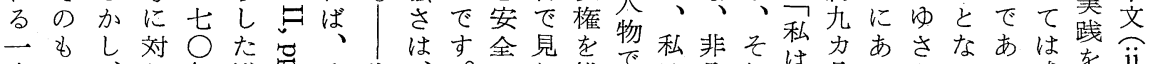

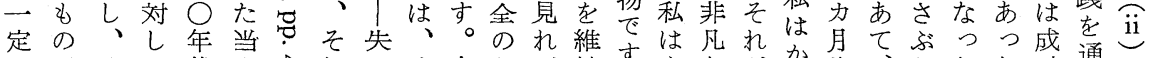

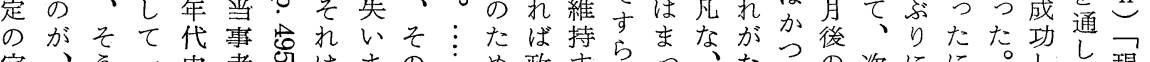

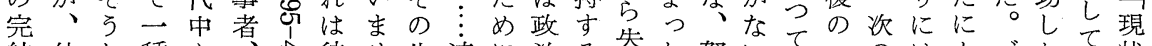
結他し種も、就彼世失連に治る敗た努いて、ロのはもバたて状 し方たの、就のらん敗中はにの敗く力場政ッょまか、前彼の

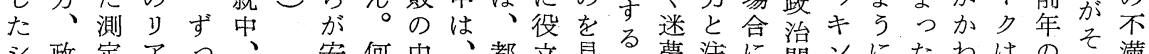

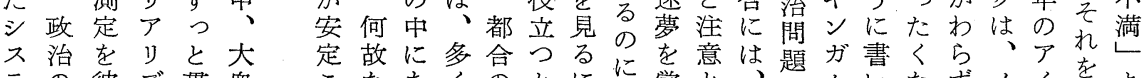

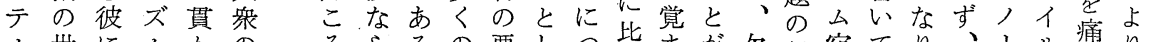

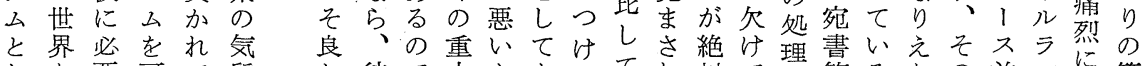

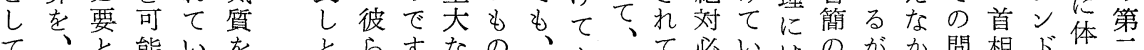
てと能いをらすなの、必いはのがか問相ド体云

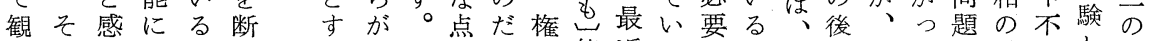
念れぜししえる信彼で、力能近またも能半こたが計在し引 せらした、ずか用ら失との力のすとの力ののこ、画地た用 しのめこそ測らさは敗強、と無。考をが部認と政失主の参

対め工促う彼験そこの政卜発

て出

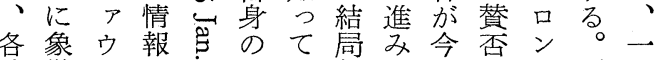
地徴ンの占失い無うやのド国七 かさド収式態ま意るお請ン内芮 られラ集 当がす味にき願そで四 のるンと原。にせうがのは年 区よド同息そ終よつ相他、末 政う漁志品でれつ、あ次かアに 府に業の罒あにてもりいらメ新 請、加連宁る乼ししま憶、議

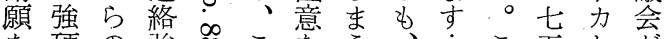

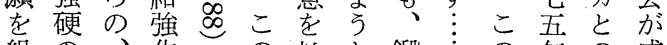
組の、化との払と鍛引の年の成 織度二を書災わいえ之情立貿立 化を二主い㕅なう挂月易し し 加 1 張てといこ指肪の加制て 、んし、混なと示、中的限以 まつンだロ乱らををし自で恶に後 たつグがッをば私維の、゙、年撃状 宣るンそン利現た持性クかを況

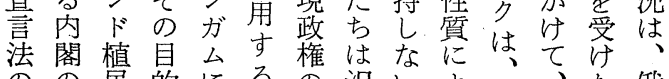
のの民篇的にるの沢いよっ、俄 撤 政 地は行で方山なっ 反 政ブか 発策の、動しがのらて薄りに をに閉二をょ、経、ど閣のス活
も1ぐ論的そつ彼をめ 対ルれ理なの神の裹、 応、てをそこ意認切そ しさ社、れとし識つの なら会同ではのそてこ いに学じあ、介のいと こあ的くるバ入もるに とる内つこ1はののよ に意容必とク不のもっ 味を然をに可卜見て 留に与性意打避、逃、 意沶えし味けと夕しも すいよにしるなルえつ るてらょてつるななと 必はとつい必で破いも 要ルしてる然あ産。重 がソた表。性ろを本大 あ、モ象ししう意文な ろのンしたな。味に時 う用テながる視し述点 。語スがつ範点、べ゙ 法キらて疇をそた、 と土も、は変こ通彼 は、、政、えでりの 〉之治むて、、リ 必、このしい歴そア らトに世ろえ史れり ずク、界哲ばへはズ しヴすの学、の、ム 
のく争は怘志据こ で勝飛国きる国何はは斗は次彼の古あス1なてつにす

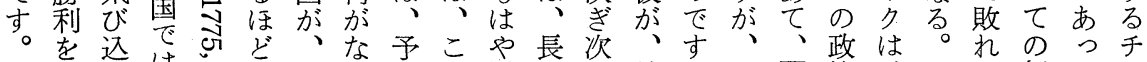

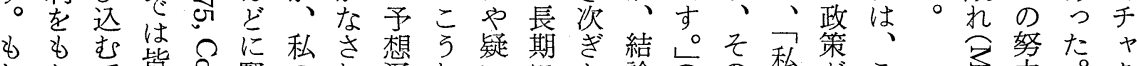

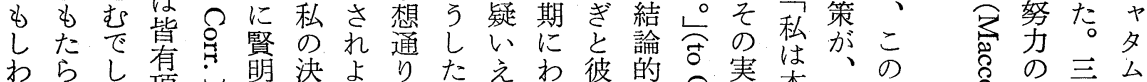

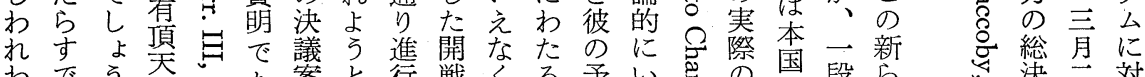

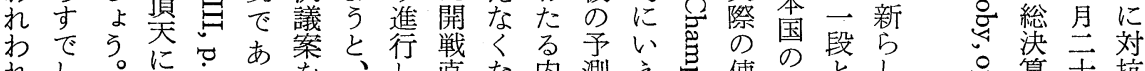

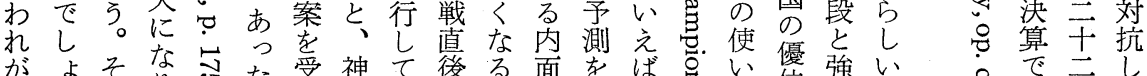

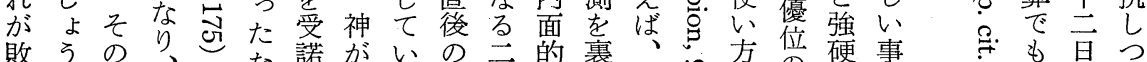

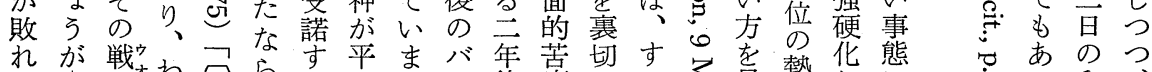

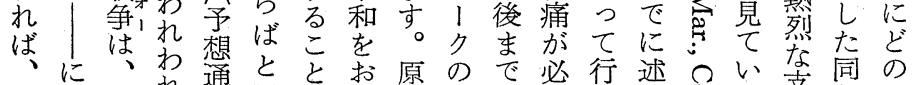

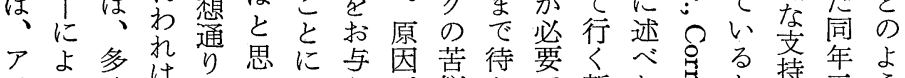

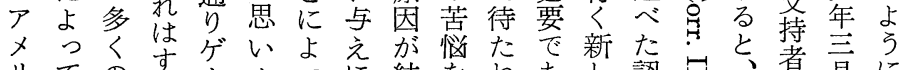

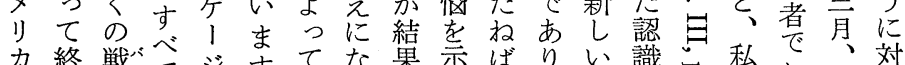

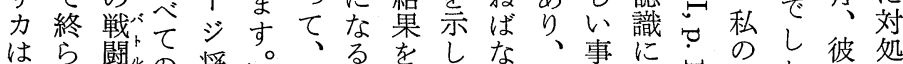

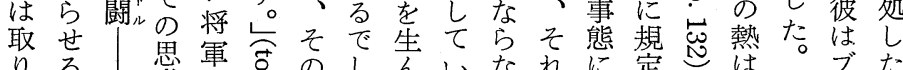

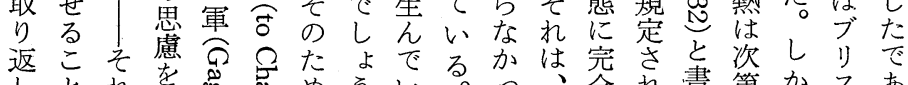

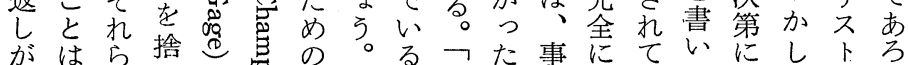

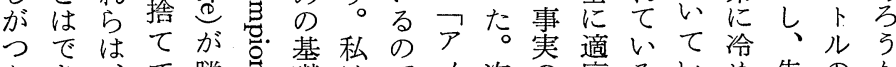

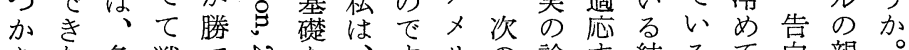
ぬな多戦て心交、す。の論す結るて白親

和了 心た解野 、汃決党 そそ案案派 直れは内 啳は、ざ 独七主 立票に噵 戦対わ表 争至た 確 の 突票れる

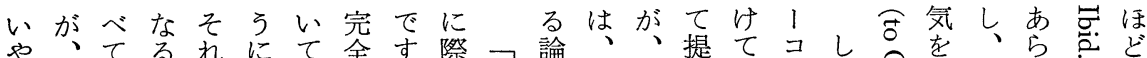

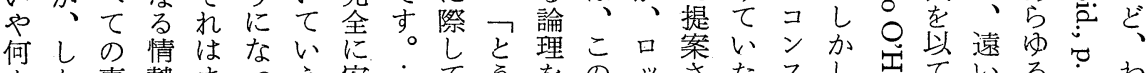

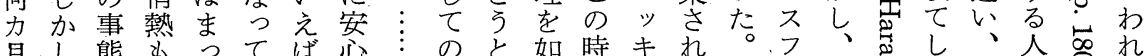

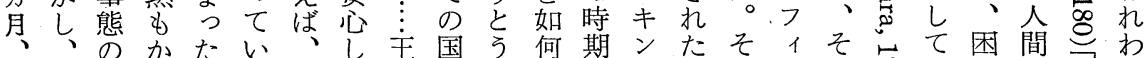
何不中きくま彼切は艮あにのガ第れ、机期的アれ 年幸で立無すすらつ、のの認バム晋らルらさ、に諸メか たに、て関: はて政一戦識、に回はドの和何充手りら つし私ず係：、い府般争しク対の、で言卢からち段力離

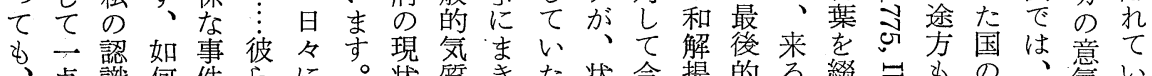
点識何件らに。状質きた状今提的る緅壳ももの、韵い

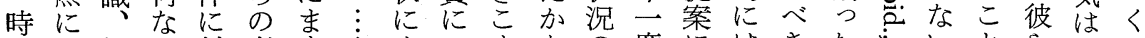
がお情る対考市

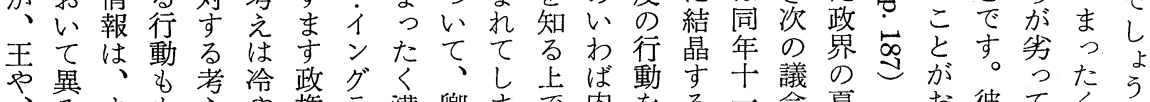

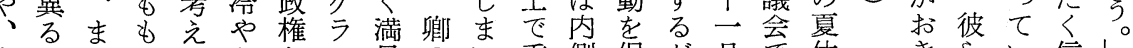

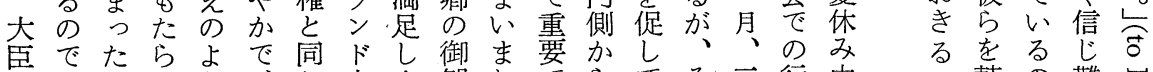

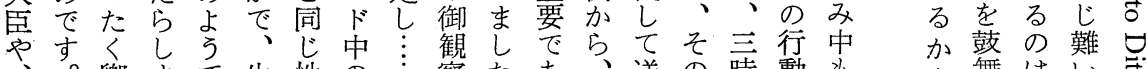
、。卿まで生性の摖た市、送の時動 方

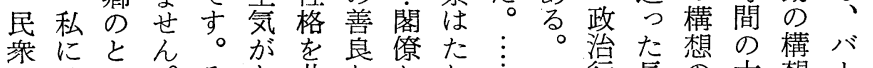

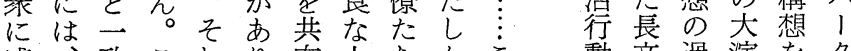
感、致これり有人ちかこ動文過演をク 覚何しれはま夺々もにの程説練は

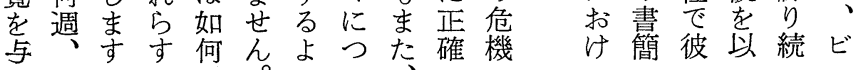
も舞 は索

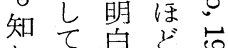
れい无吉 まるす。氙 せあのしう艺 。意加 
中たれ廷戦に 加ちず派争よ

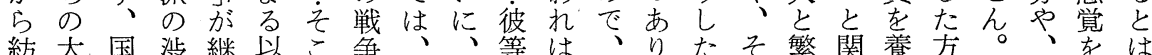

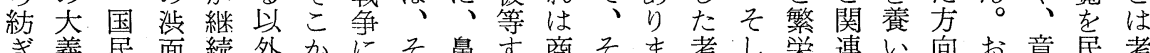

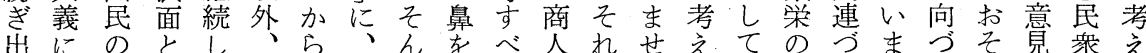

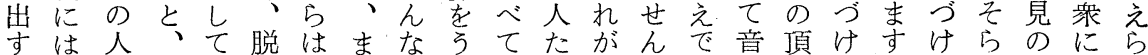

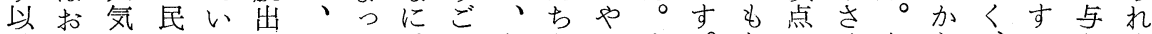

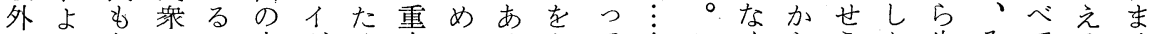
に之なの加方ギく大加る加て

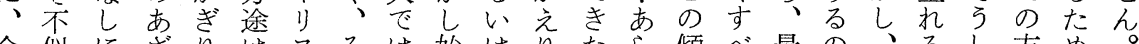
今似にざり、はスそは始はりたら傾べ最の、るし方め の合、け、あをしあめそみ時ゆきり底で行のた向に現 私な強りそり侮てりてのま、るの落のす動で意うは在 た、気ののま辱決まい大し何事中ち愚。のす見け、の ち小で口権せ高定せる多たの件でる鈍：みいやは計や” にさ、笛力んる的んの数。鳘怔、でと はく気のの加に居彼き、特あ番事、件分少と方么

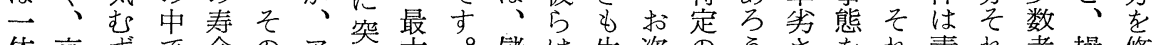
体哀ずで命のア等大。儲は生次のうさをれ素れ者操修 何れか、劣状メ込の 线反く

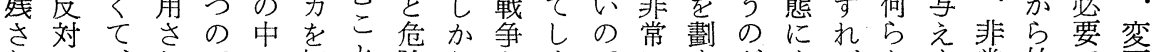
れの、机で奴と険しとまでにすがまばかま常始で更 て糸私ずすは隸では、いいす良る、で、のすにらすすす

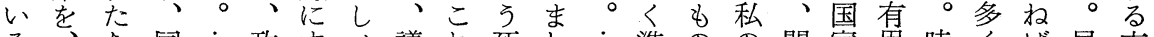
る、ち同 $\vdots$ 政すむ議れ死し と腹と意 $\vdots$ 権るう。会ら体た

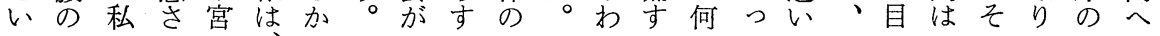

ヨでさういけ現で異でょ早

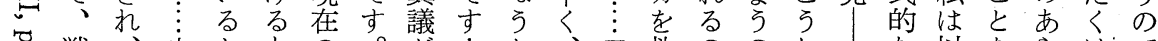

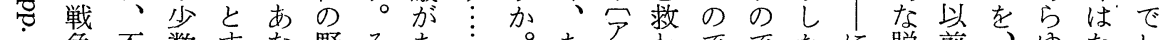

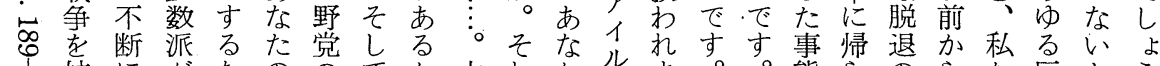

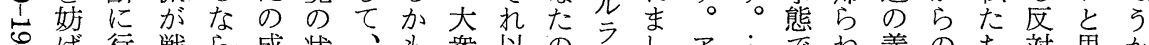

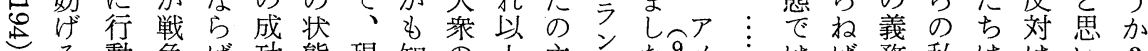

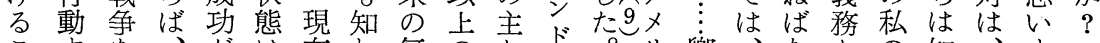

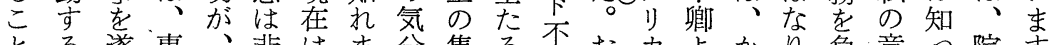

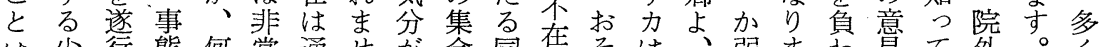
は少行態何常通せ肪会同在そは均まわ睍て外。く で数すは加に常ん熟古志地らあああいせずすいだ

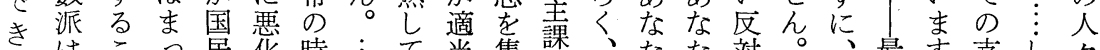
るはこつ民化時

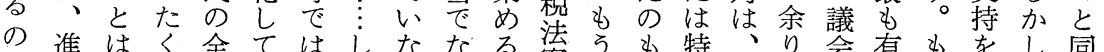

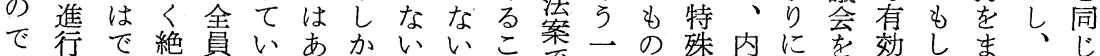

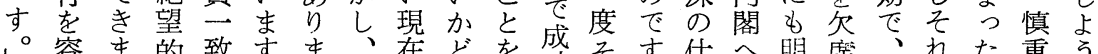

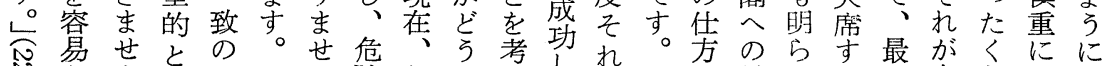

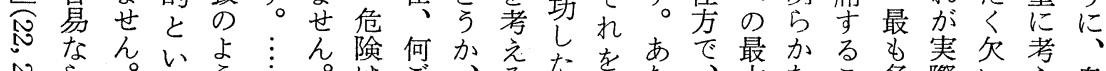

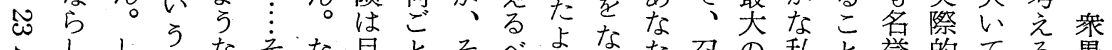

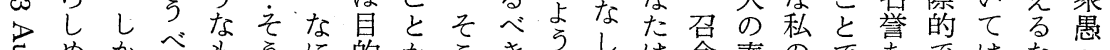

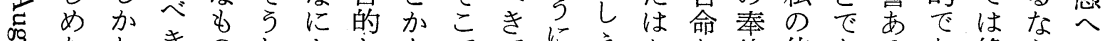

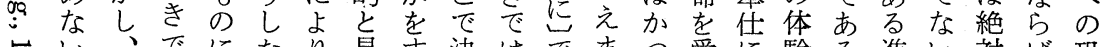
シい、でにたり見す決はでまつ受に験る進い対ば恐

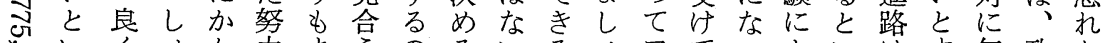

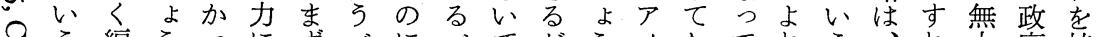

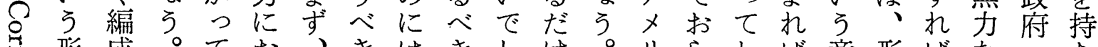

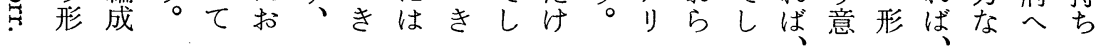


し対性に会ばそものと来まのしさ眠保さ者連植 ス て話右た㷌と与しま舞ど無さ、にもつ持れた合䇙合こ 行をのけしい件てた台ま意に状すなだなるも地閣こ

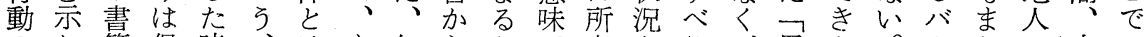
のし簡保時、はも無らたで马をりば民よ。1たの本 慎ては持に本矛し視姿めはた構落、菜うでク分気国、 重い、さも来盾もさ壳になあ成ちれイのかはは裂質のク

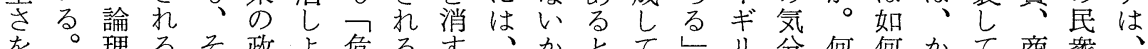

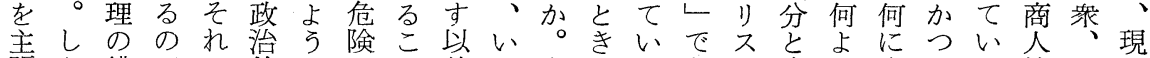
張加錯でに的とはと外わ尼るるあは意り毛てるる等ま状

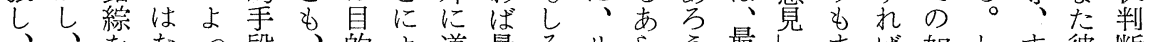
をなっ段、的よ道最そりらう。最しまば如しす彼断

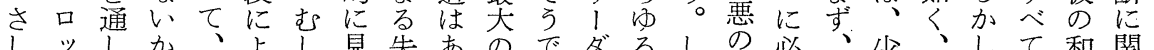

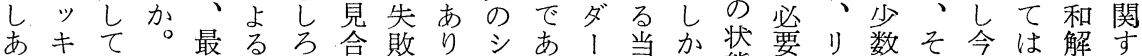
たン、低べ、うの方ョるシ事し熊な1派のや彼政る つガこ 限き同べ危ぬ シとッ者、に方ダと認、に策か

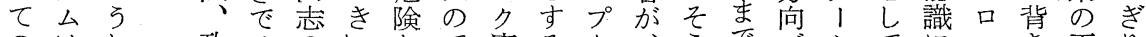

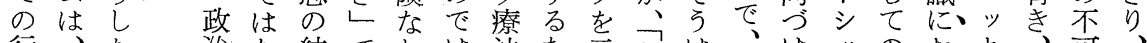

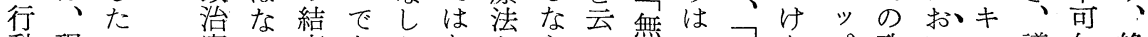
動現バ家い束あとなとら々感い間をプ政いいン議欠絶 に状、とかれるしいへしばす筧つ違与の治て、ガ会の望

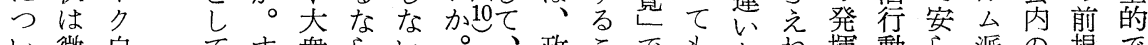

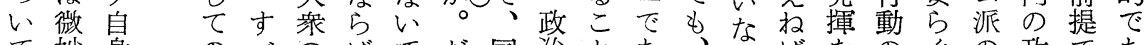
て妙身のべ有ばでだ同治とあくくばをのぐの政であ 、自て権っあが派の自る自、な通有こ下府方る

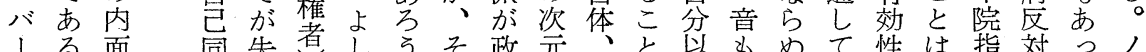

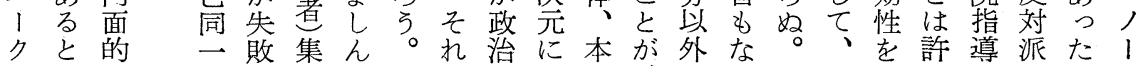

はに的き運どてっどぬそう的 方クず院た寄衆〕の

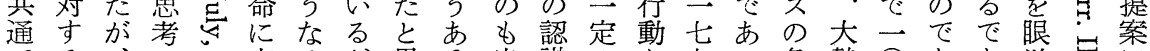

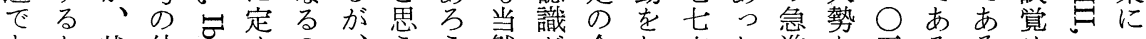
あか 状外怘め の

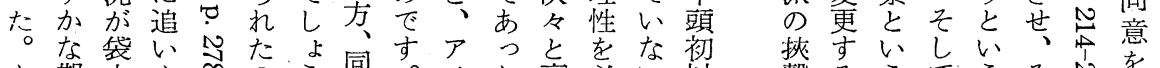

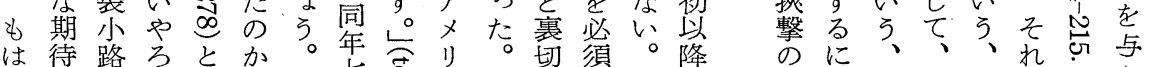

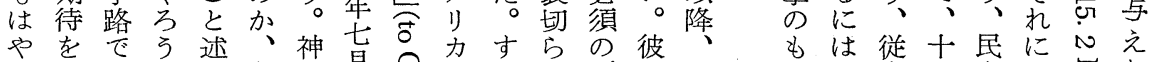

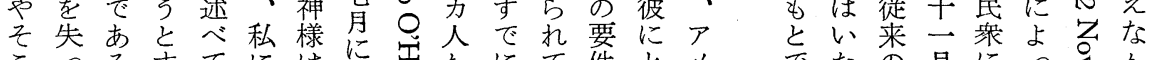

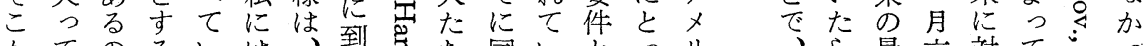

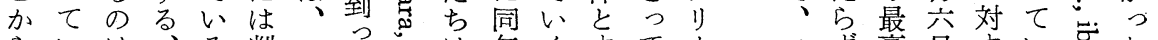

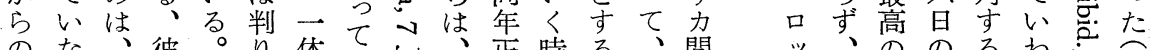

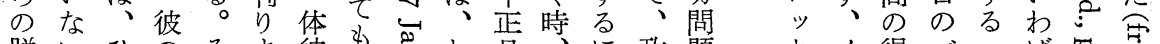

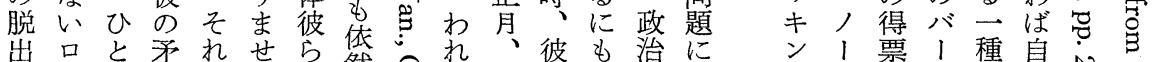

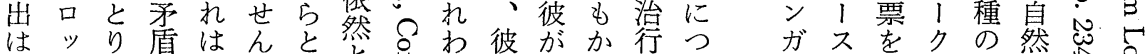

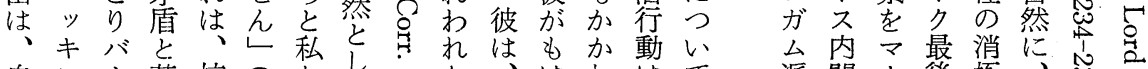

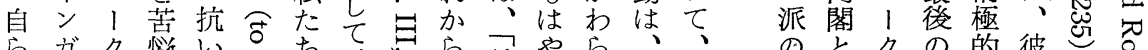

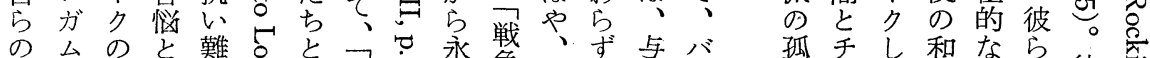

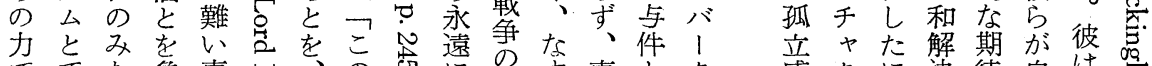

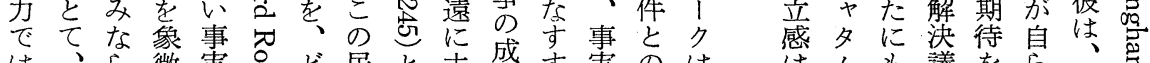

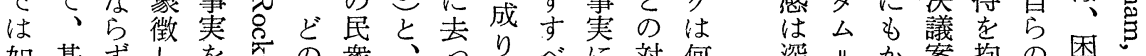

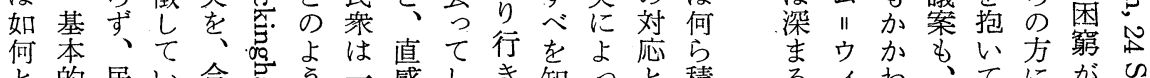

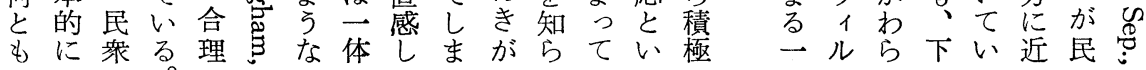




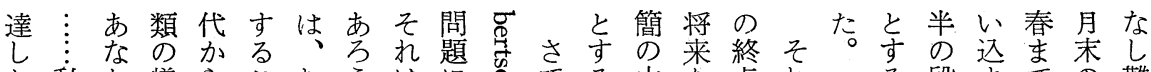

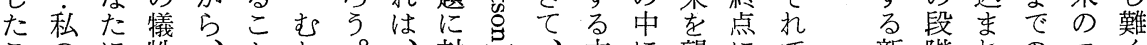

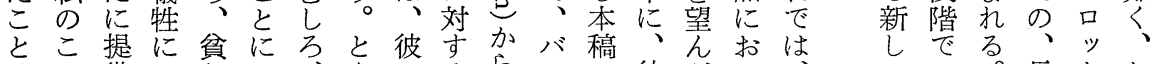

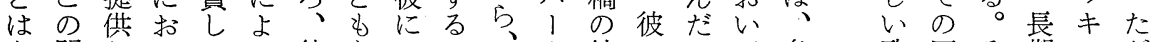
あ問しいいる彼あとバそク結のでて多政同そ期ンだ り題てて教自自れつ! そはび政あ、大治派しのの情 まにい歴師息身彼てクの、治ろバの 状のて議么勢

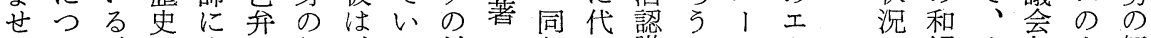

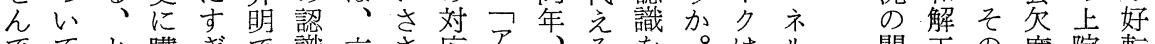
でてと購ぎて識六さ応アメ、るをを。はル 開工の席院転 しのいわまむの加のメ著こた产をギ始作失とでに

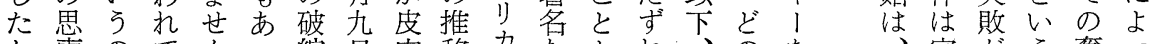

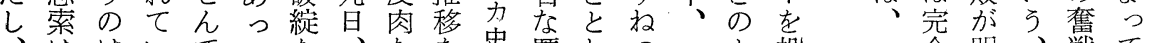

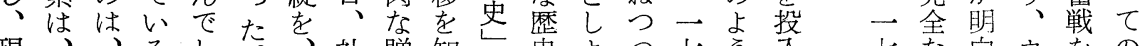

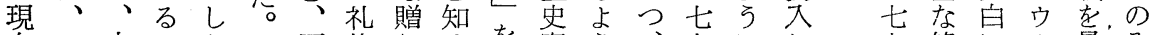

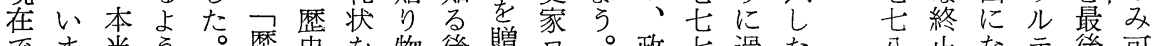
でま当う。歴史を物後贈口。政七過た业なな後可 そな゙にな゙ 悲類 そか悲類

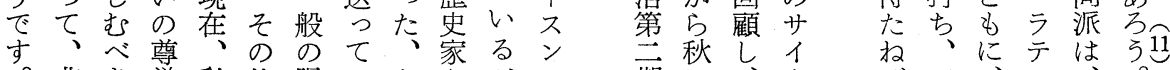

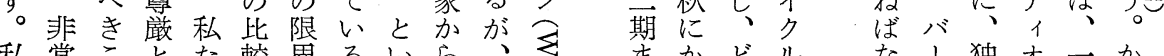

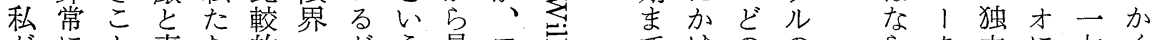

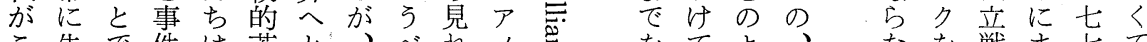

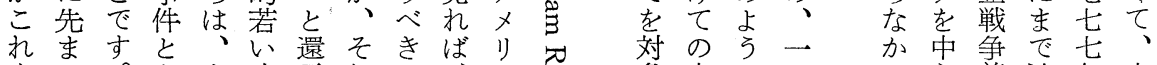
まで。を人時元れだ方兑象書につつつ心前追年十

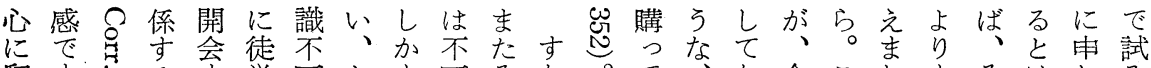

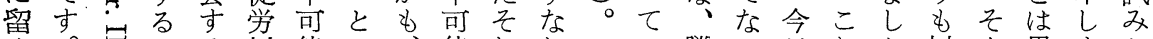

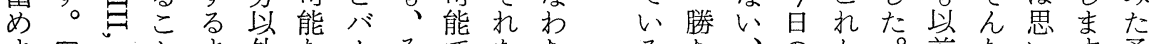

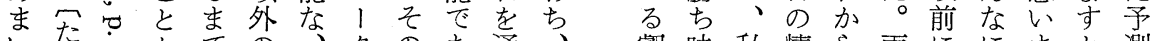

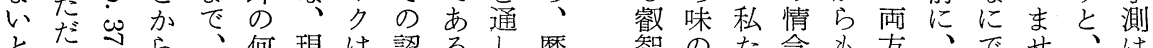

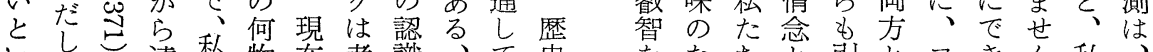

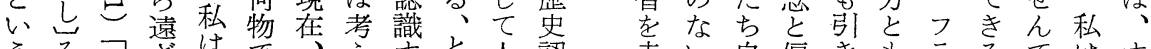

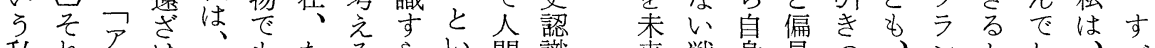

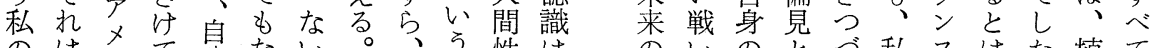

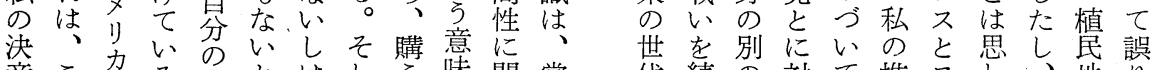
意こ閏る気とはし

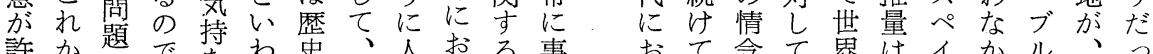

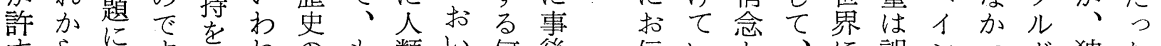

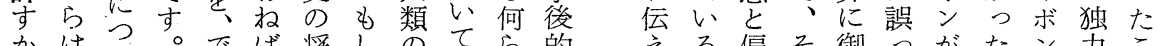
かはつよでば将しのてら的方る偏そ御っがたン力こ

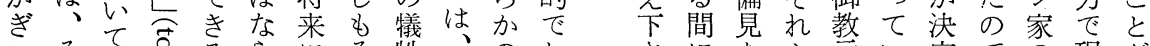

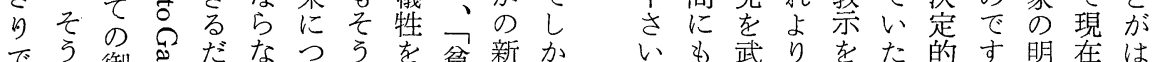

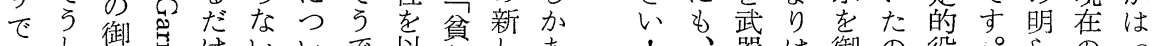

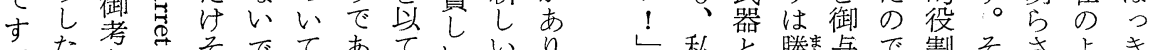

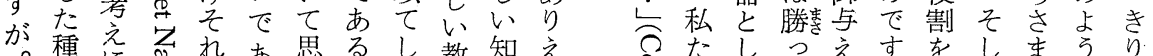

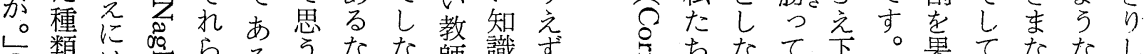

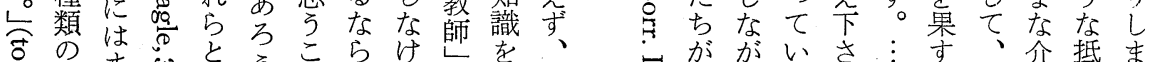
○事ま

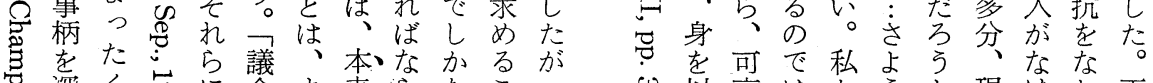

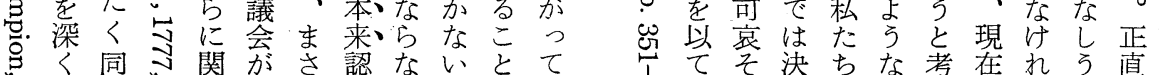

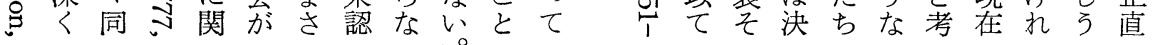


用戦しをの年ウに七すゔバそがそ的姐ら夏れ折寲心 を争ま物中前1向五るく（の、うに究れ休る感だ的

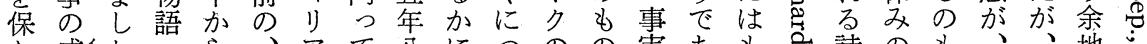

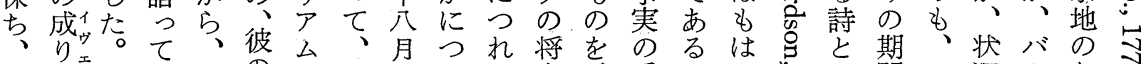

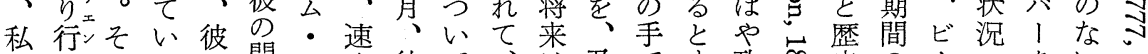
たき”のるの䦗べや彼て、は及です政 $\underbrace{\infty}$ 史の

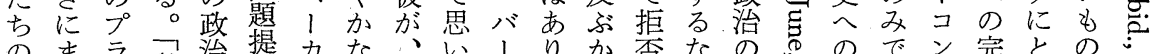

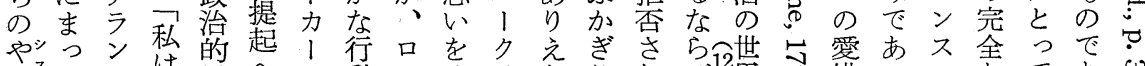

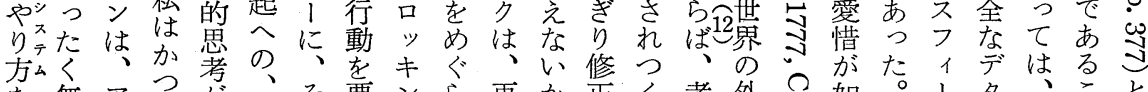

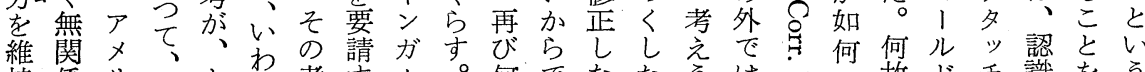

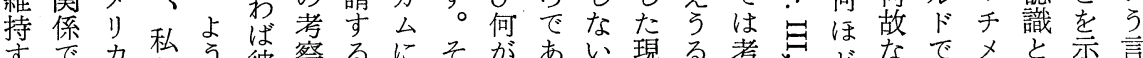

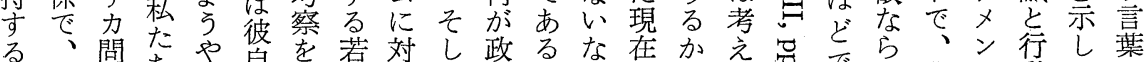

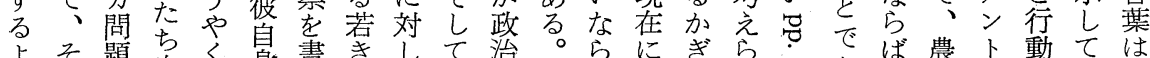

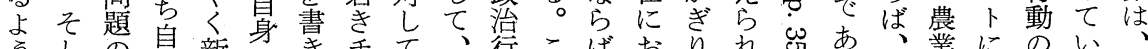
うしの自新の身手て、行こばおりれ岕あい、業にのい、

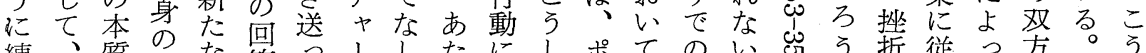
練、質の確な答つ、したにしポてのい岕ら折従っ方。

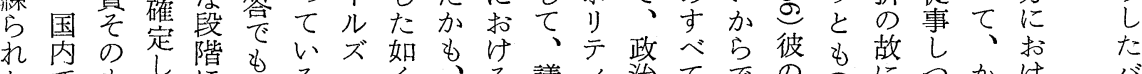

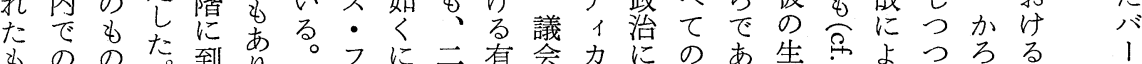

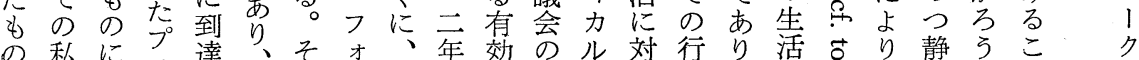
の私にラ達、そオ、年效会ル対行り活すり静らこゔ

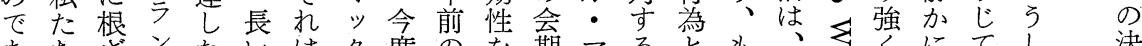

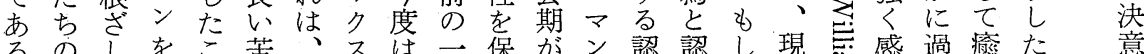

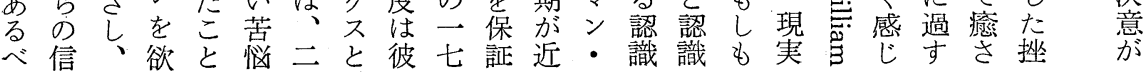

戦持ま奇種と私で彼私少んまられら卿がとのに信経き 戦持す妙の、たあらたしどせすばはと名忹尔はし験だ 争ち。袋不ちるのち同慰んべ、、そ声で陷、ててかっ にな：拉小可のか方の化め。て何いのとをで私いらた 扮さ てい急によた詮、傾にるなう変かば志てせょちす今で

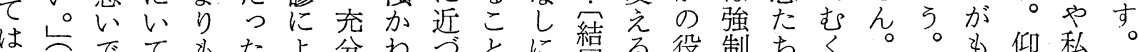

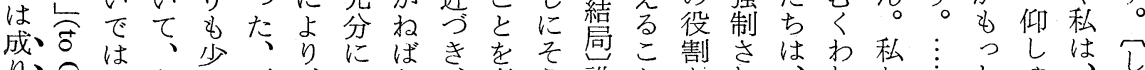

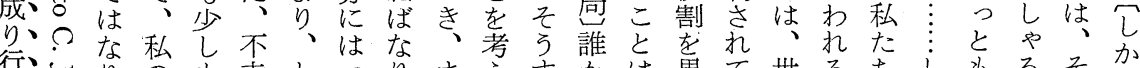

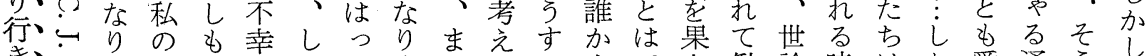

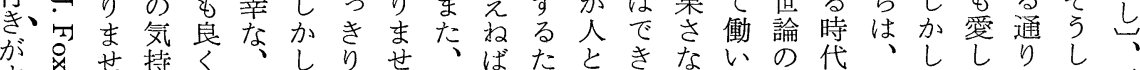

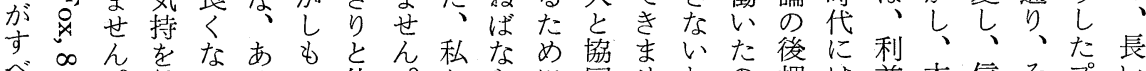

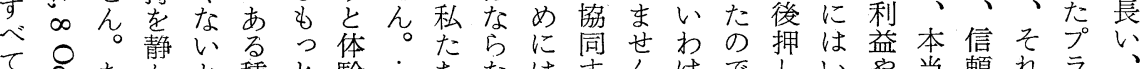

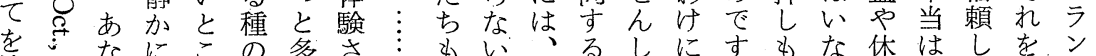

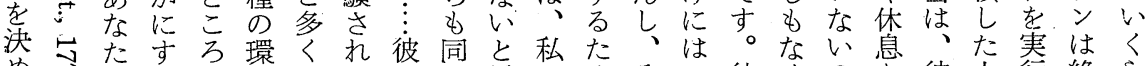

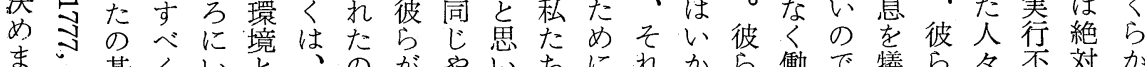
ま。基くいと、の汃やいちにれから㗢で犠ら々不対加 。礎あまに私で何りまははになのきす牲をの可的は

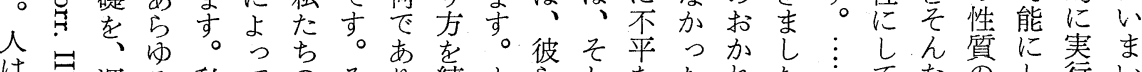

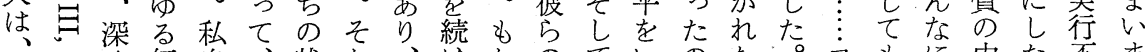

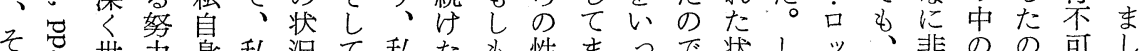

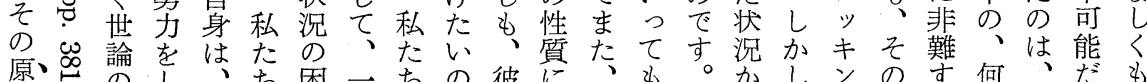

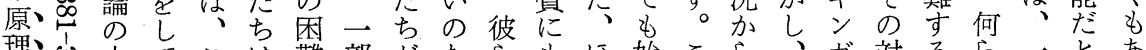

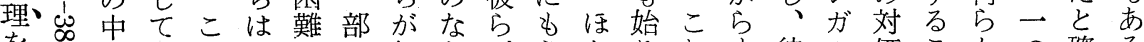

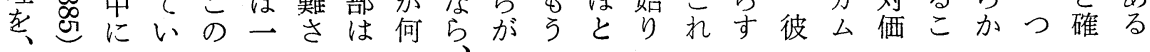


るれはす政体そかの自る 豆主に否そ䭾?筆っ衆そ成

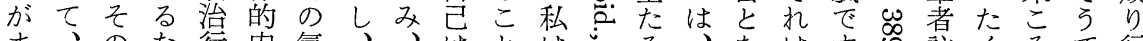
ま、のな行内気、、はとは它る、文はす包註くそで行

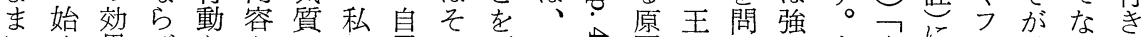

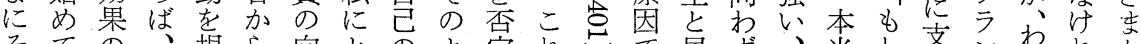

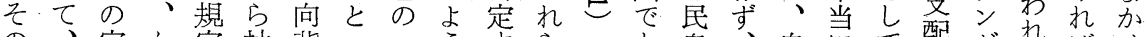
の、定加定抽背つつう卞ら市衆、自にだ配ダればせ よ合か?すす象にて気にるの う理なてるさ決見持なの言 な.性ら二最れ定逃のけ、で葉 もあ好年大、的し安机はが のる、前のそにえらば、も

で政りに要の低なぎなとす あ治 1 考因意存いしらよで るのダえと味すのをなりに 。範 こ 疇 シれてはつ、出ついて のとッた認ま成こさた゚き 考なプよ識さりこ衫し依な えるにうさに行にば、然彼 はのよにれ不きおなまとの 具は方民放定がてななた思 体な问衆との、始いそバの 的くうとでまれぬでの に、けはあまいのてあ中ク長 は本を、るに個、るににの

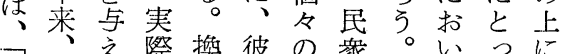

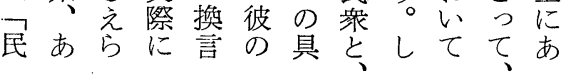
りとそ然主されるれなに い机の本れ机机らし 後らに手当ばる手加手ぬて 者二従芯に手古 直段感な そのわ品私しずす市すずり

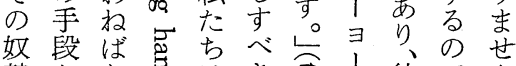
隷しな弆はき市! 彼でん でかり虽成だ方ららすが

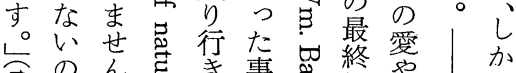

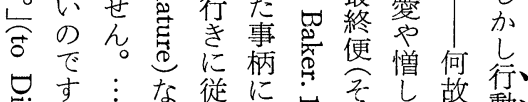

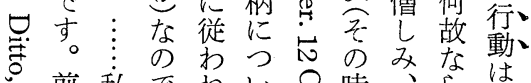

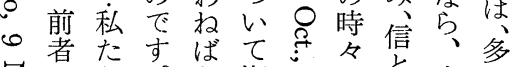

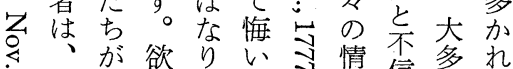
現働欲ま い光情信多れ

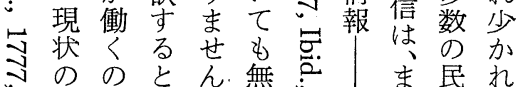
、゙ の の と

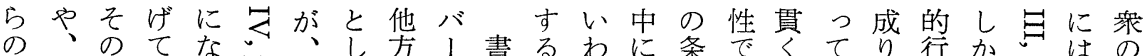

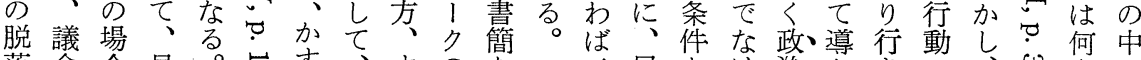

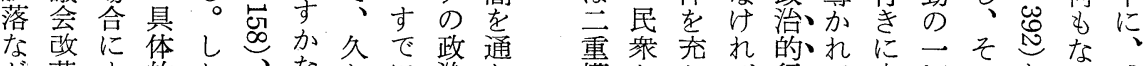

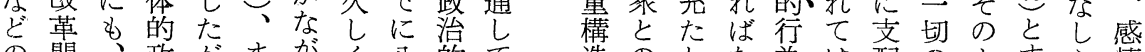
の問、政がまがく公的て 造のしな為は配のよす情 挫題さ策つたら待九思眺をな、てらはなさ放らるるな 折にし活て、そ感望年考め持り、始な、られ霜にに口い大

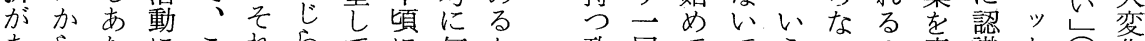
あらたにこれらてに何が政層てたらいの意識キ苦花

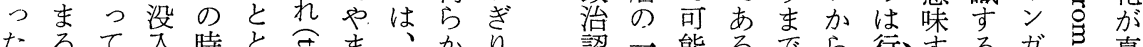

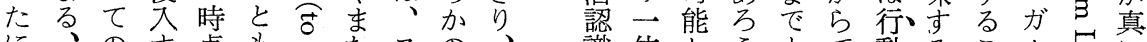

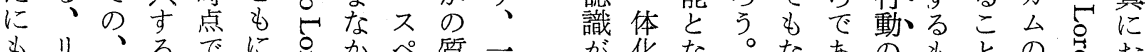

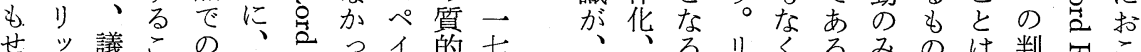

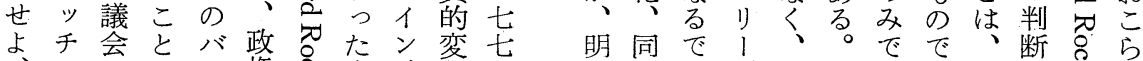

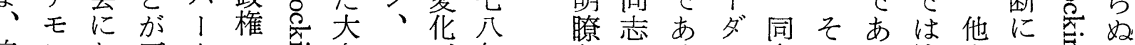

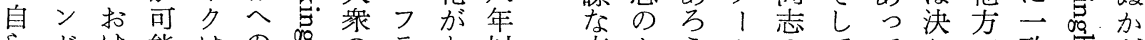

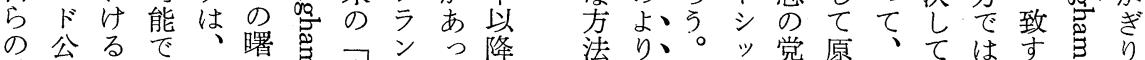

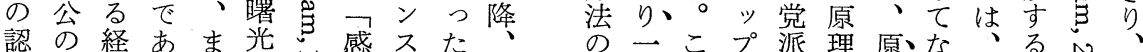

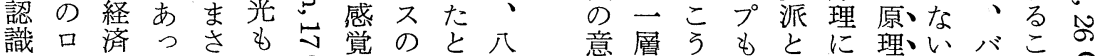

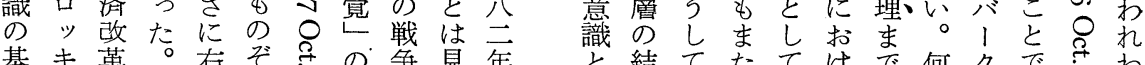

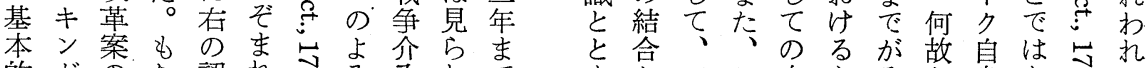

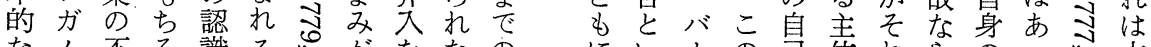

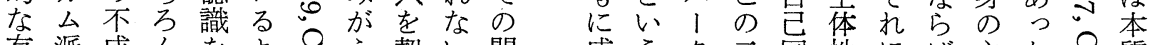

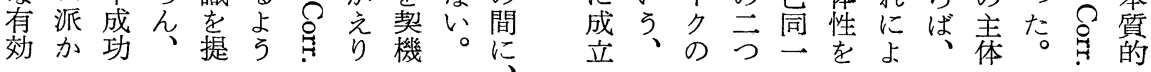


きバ己ばあべと部ばあ連べ不に

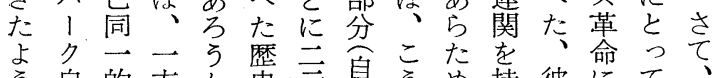

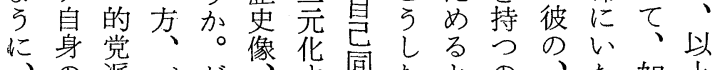
、の派バた像华同たとの、た如上 バ自な、が自る的政しか非る何あ クにるク、然可的治て。政のなる にほの考のの性派識後者的あ意け 扣かのえよ三をとは者の諸乃味て いな実るう元内芮、、に問問うをき てら体政に化包し政つ題題か持た なは治考としか治いにに。ち第

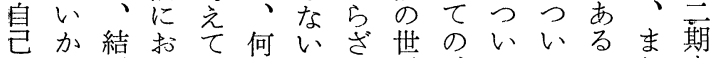
がも局けむらでる界、てていたま 自知はる、かあ部を一はのは如で 己れ、認なのろ分机っ、認逆何の にな政識捄分う危まの資識にに政 対い治可問ラか飠た推料と䩦治 し○の 能題レ。緑、論のはそ正認 て他世の梳をれそ合を刊、れさ識 明方界要残をれま理あ行如は机标

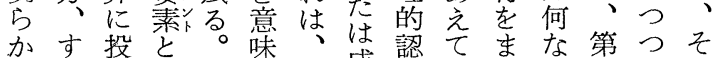
とで影し何し前成識すつる壬、の なに京て故な節行可るて 内節フ 後 る見れのないに行能な稿面にラの のてた自らで述きのらを的述ン彼

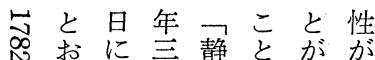

立も再吕をで保 占、のな期きた 占彼第満待たれ

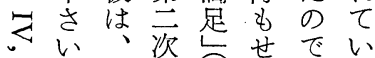

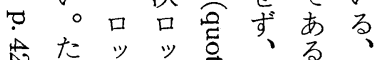

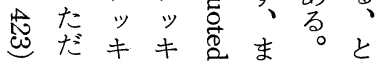
と艺ン ン 強つ、゙ガの現う識 くのム

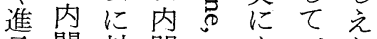
言閣対閣各もバた しをしの? 加 I 加 た岕て成导えクぎ の あ゙すあ日它な彼彼

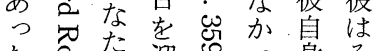
た合の迎包つ身そ 穹基る る 苛にそて文のに NLL二加に耐

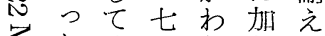

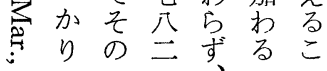

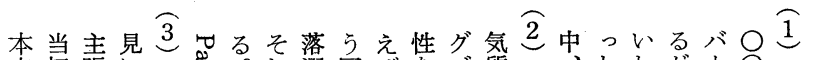

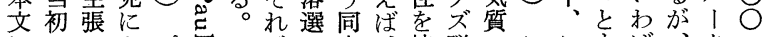

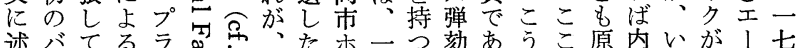

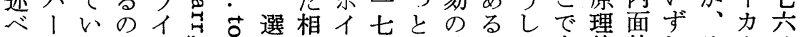

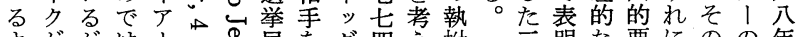
よががは、蛋民をグ四え拗一三奛な要にのの年

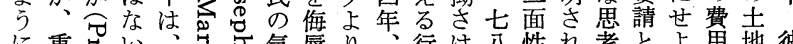
飞重马.

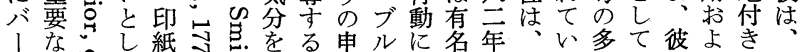

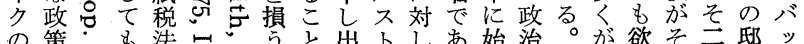

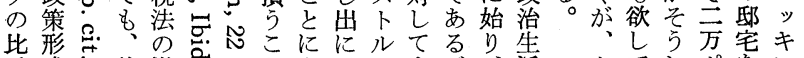

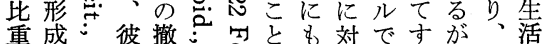

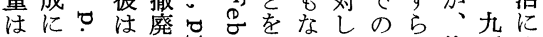
资与 8 そ第恐るて当他五入

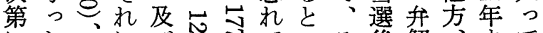

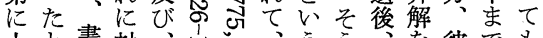

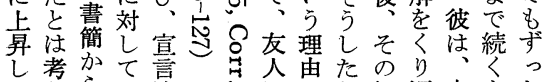
七考吕て言 て兄か法 るれるり制 がなかの定 、いぎ役が 七勿り製バ 七論政果 三界しク 年後入た。 のにりと意 人者だ行祝返自市々 寻文拒動賀迋方才受 り否は盗こは1け 它なし思吉レ充レっ

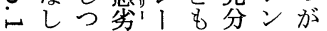
もをつでドあな・杭 依もあをつ内へる 。頼、り行た面イバ

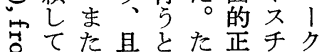
クてしポをシ リいたシ求ガ スた場ドめム マこ所をたシ 不衣算こ経引 復重なで済の 活要る調的ビ 祭で権達に あ勢しはコ 及る欲た、ン び。とかむス 夏政しはしフ 期治て謎ろ の生でと貧 । 議活なさしル 会中しれ加 荟もにていた六
れ述しで有らは 時以牛な意常 期て図い政識に を満式、治す事 対足化と行 る 後 象す架い動に的 とべ本うをもた すき稿こ準せし るだのと備よか 本は最にす、あ 稿な終はる党り のい的な確、派え 筆か意ら実のな を、图なな原い 擱とない担理 考ので保はと こなであと充な現る とがなうて在な

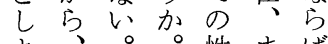
よ、。性まば う。ひ思し格た彼 ま史し持将自 する 限たするおお如 定机主什何 さ叙にのるよ 


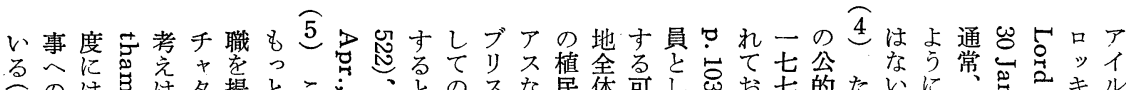

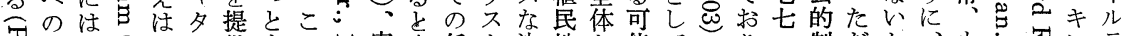

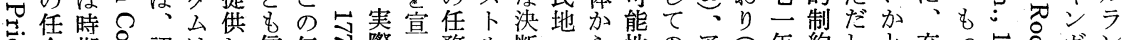
命期吕認

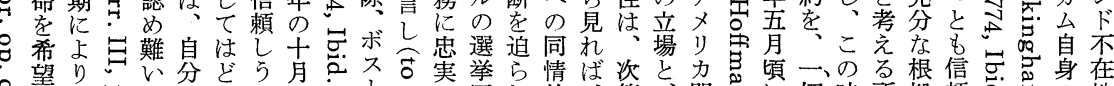

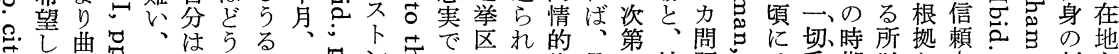

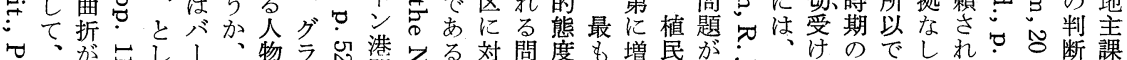

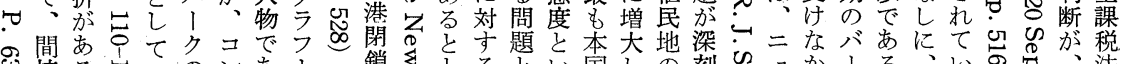

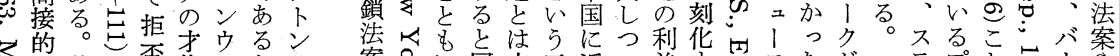

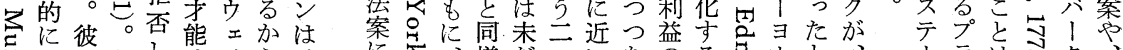
ではなし注くら天 注抒た認斥、中 あで、向め同彼夕 するにバする意の台 が一।号け見望に

吕ピ只尔でん対 シッ五のすどあでし

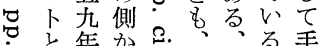
交、らさ貿とら紙

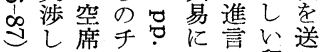
が、拒又タc心つし貿り 一否ドム\&てい省バ 七さラべのるで। 六热不の彼がのク

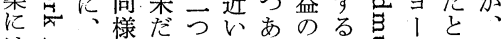
は議感の立っ代に寻方口

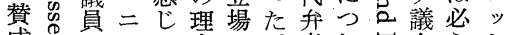

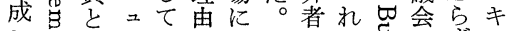
し吉しいにあしと者のずン た岕てヨなよっかし、质口しガ の心の!かったして宣てンもム

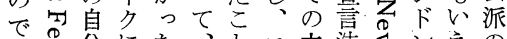
它分にた、と二立法もンえの ○方対。彼二場を热な゙

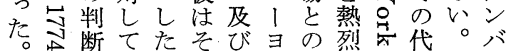

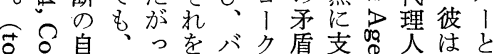

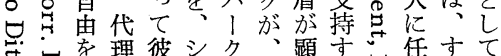

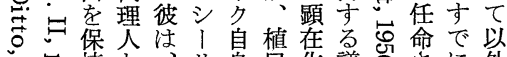
。? 持と、リ身民化議导さに外

। ツイ、のア マア第号進 ン 1 三言り - の期云以力 バ伝以こ前問 記降守に題 少它存初 をら, 怘在 期 過、大しの 大第き灾て頃 視一筑店いに て節差盖宁たは 指莫含す る摘あ吕灾

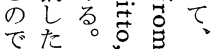

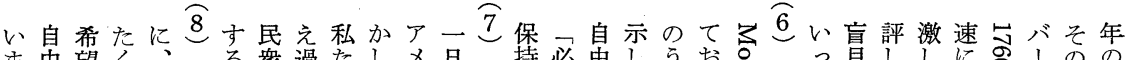

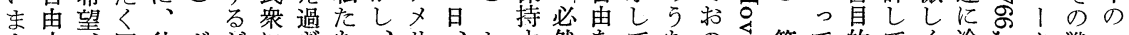

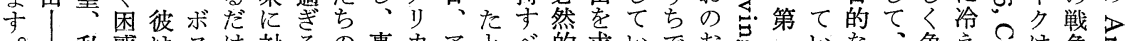

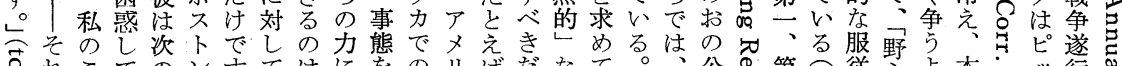

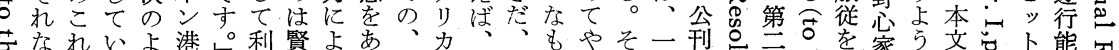

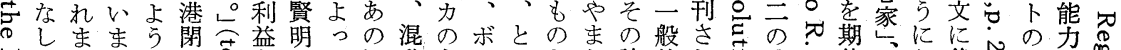

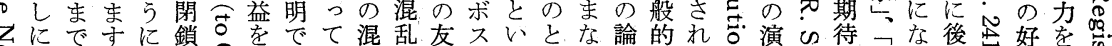

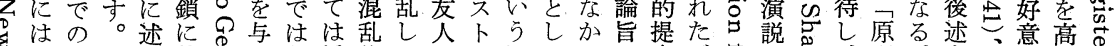

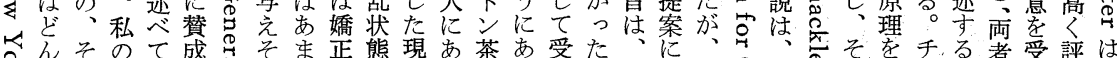

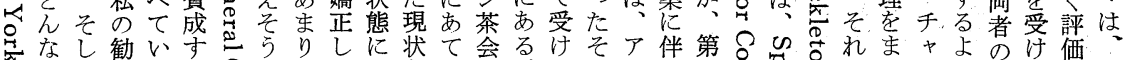

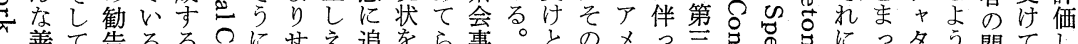

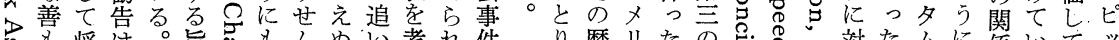

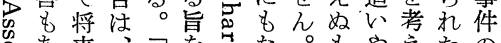

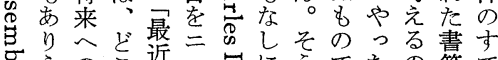
壳えのこ近こ施らでたの簡で ま努で非：、しし過ははに

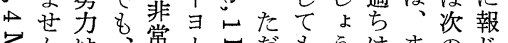

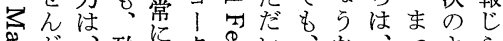

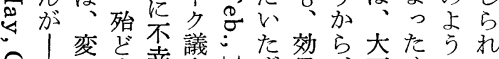

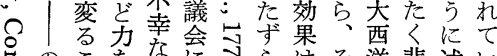

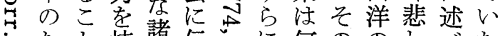
曰たと持諸伝らに何ののしぶた

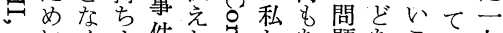
り之ま件た鸟たあ題ちこい七

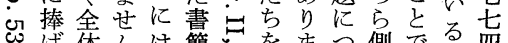
导げ体んは簡志をつ側でる。四 これ善私ま最它安んてです。年

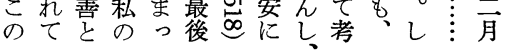

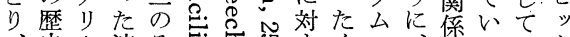

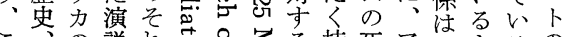

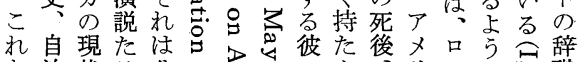

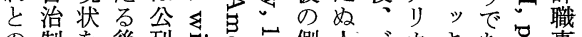
の制を後刊空。实側人バカキあ它事

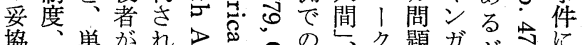

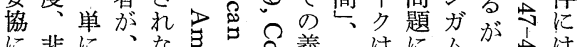

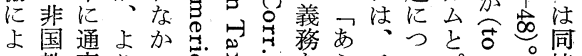

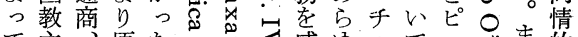

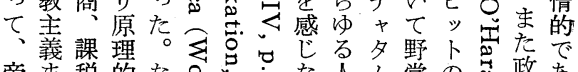
帝ま税的なっ马政あ

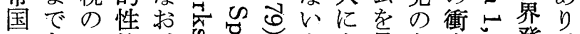

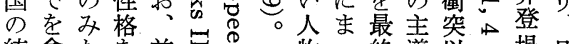
統含な学前占物口終導以場且

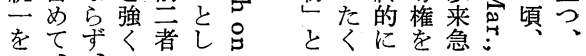




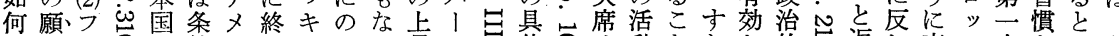

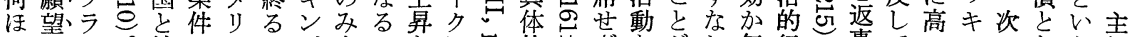

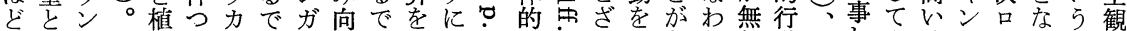

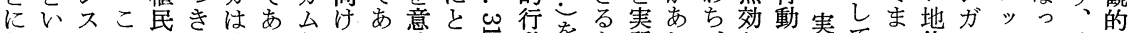

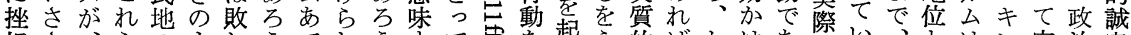

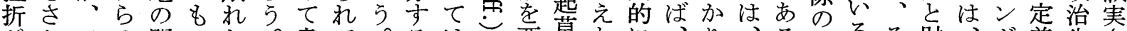

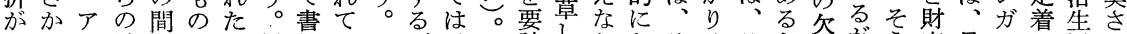
あもメ予のとり(2) 簡しこ济し

ろ矛り測仲なとアでまのか状

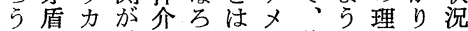

としと、的 5 以リ彼こ冎での な結 (1) 学。え力沈光な好 バ、ん本をと注とらく転 1ので国と、完近 (1)な、、は クは、のるう全くフる彼同 に注イ優べ予に本ラ。の時単 と目ギ位き测届国ンす予にに っにリのでを服にクな測、議 て価入もあ立于和りわ彼会 考すととるてるをンち、自内 光対でと、求の、必身で 5 。立の主木とめパー然のの る艺英張イはる七的認口 生な帝しッあでで七に識ッ 活、国てグるあの七一のキ は、のいは委ろ援年つ妥ン 政と平る、いう助一の当ガ 界、和合こ加。变月具性么 にらの凤のら(3) 涉六体の派 乙 恢马場、しは旦的証の 請し汃なそそと席驾ら産最公し活の しま口されめ扎戦密しの後内て当確 てまた称はにを単術哭た所的閣い初認 いた事ばるも遂純の徘有手でる以に る各情な最尔行に最ら常者段のこ来よ

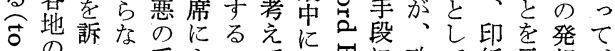
の訴なのにるえに手よ段政て紙示想て

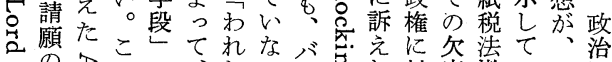

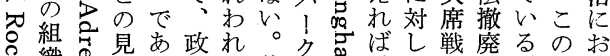

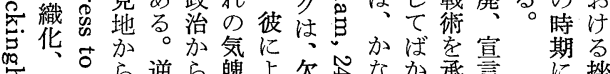
㦈号逆ら魄よ欠灾なか承言に挫

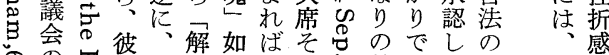

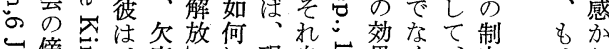

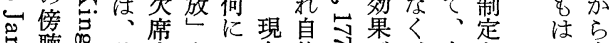

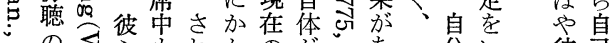

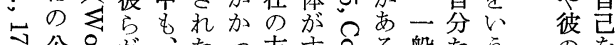

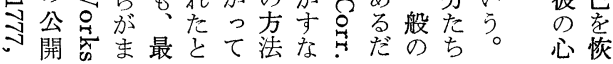

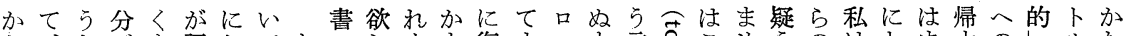

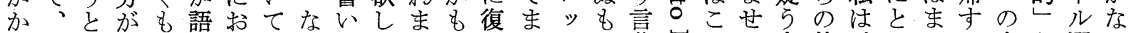
わ如主ブ—つけ二抒ててで何㾍でキの葉占こん余善、゙っる失と選か っ何張リ七てる言、いいのごすしンではにに。地をもめたの望し挙っ

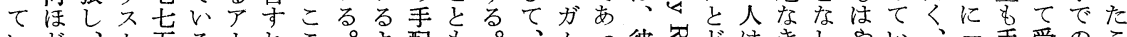

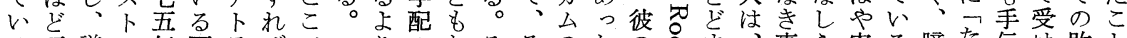
る不議ル年両ラばでりのなそそたの员ま事え実る臆た伝け敗々

と快会上四者 又、 㴏でり月の・そ余 らあの選に対バれり 万活出生立।はに 事亏動さ飞゙のク、も 実とのれた過々要有 は自た次程、守名 事選由ののに現るな 実举をは事つ実にバ で戦放、件いと あで谼選たての本ク るの粪讨、衝文と と個る民委詳突にブ 手人このあしのもリ るのとすげ々象述 反利をこて論徴心 論害拒奇扔ずにたル が务杏こるほよ選 同寻方余吕举 䒾命息す裕なな、 のク1のななないの 一のクのわ当わ確 商当にみちが。ば執 人選対に、、書政に よにし負自早簡治つ

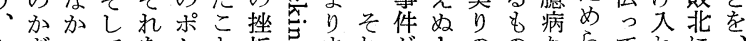
かぎってをケを折品まれが、とののらてれに なりた、バッを感总しに神確なが、以以、゙か関も

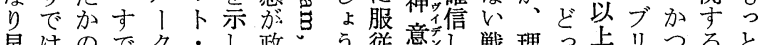

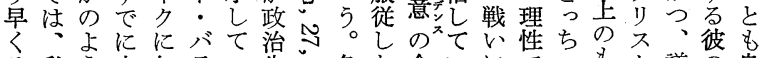
衣私 $5+$ 十

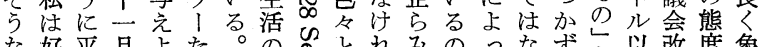
な好平月よた。の包とれみのっなず改度象 るき静云 5 るし終导考ばのでて方感外革で徴 となに百とモかりちえな暗すはて状感のをあし

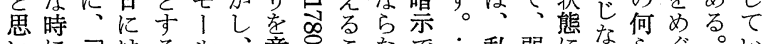
、にコはるル意。こなで：私弱にならぐ。い

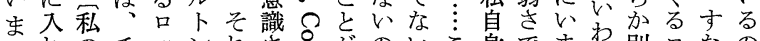

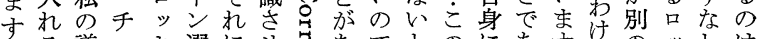

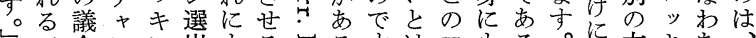

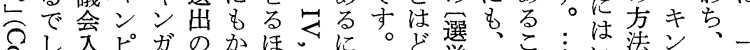

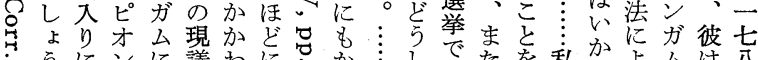

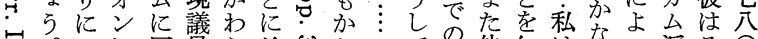

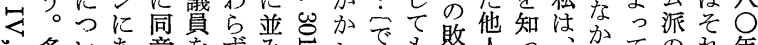

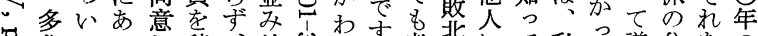

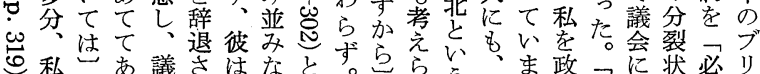

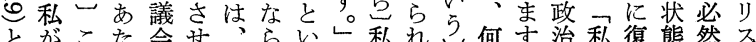




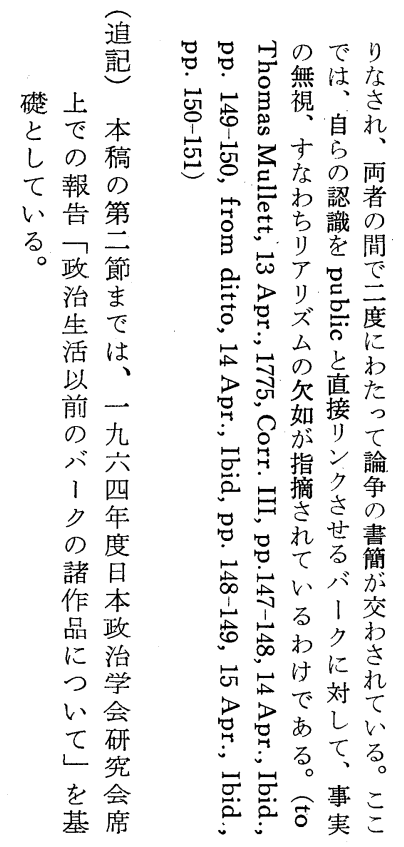




\section{A STUDY ON BURKE'S IDEAS OF POLI- TICAL, AESTHETIC AND HISTORICAL KNOWLEDGES FROM THE EARLIEST TIME TO 1782}

\section{Takamaro Hanzawa}

Anyone who takes a glance over the whole history of Burke studies from his death up to the present should certainly be struck at various and sometimes mutually inconsistent interpretations. We now have many Burkes, such as great statesman Burke, romantist Burke, utilitarian Burke, democrat Burke, Burke the prophet of Conservatism, Burke the natural law theorist in Thomistic tradition and so forth.

The writer thinks, however, all such Burkes come from quite the same premise; the premise that we can have a political philosopher Burke free from theoretical contradictions. This article argues that it is necessary to change such a premise.

The writer does not wish to describe what political philosophy Burke advocates. All that the article wishes to make clear is how he recognized the nature of the world of politics, through the inspection of his whole treatises and letters before and after 1765. At the same time, since Burke is not only an ordinary politician but also a literary man fond of talking about history and literary criticism (especially before his entrance into Parliament in 1765), the writer also tries to draw some parallelism among his ideas of political, aesthetic and historical knowledges.

First. Burke's basic view on historical and aesthetic world is very near to that of his contemporary Hume. He is agnostic of the essential existence. He tries to secure the certainty of his knowledges through reducing every sensible object to the utmost of its simplicity. But, notwithstanding that method, he always has a desire, consciously or unconsciously, to know the world in the wholeness. Hence method and desire contradict each other. The result is that, for instance, his idea of the "necessity" of historical world is divided into two in its meaning ; one, the necessity of mechanism composed of cognitive elements, and the other, that of transcendental will of the doers.

Second. Of politics; The letters in his earlier life in Parliament show that he strongly feels that the room for choice in politics is very small to him. Very important to the writer is the fact that he extends the conclusion derived from this personal experience to the idea of the world of politics in general and says that the nature of politics is also a mechanistic necessity. Since, for instance, he sees the theory of Lockian social contract not from the side of free choice of régime by its members, but from the side of irreversibility of the state of nature, or inconveniences of the dissolution of governments.

But, if it be true that the method of analysation into the ultimate elements is the only systematic way to know the nature of political world, is it also true that this nature is necessarily a mechanistic necessity? Firstly, the element of the "spirit(or temper) of people" which he often mentions always lacks concreteness in its contents. Secondly, the element of "Burke himself" is also uncertain, because, according to him, the knowledge of himself is always post 
facto. Thus, it is no wonder that he was "never forward in his speculation" in practical affairs.

However, Burke is a flexible thinker. Through the difficulties of his party and himself at the time of the American Revolution, he gradually modifies his earlier ideas on the nature of politics, and the result appears before 1782 in the following ways. Firstly, his letters in 1778 addressed to his intimate friends emphasize the importance of the unity of his party members and the consistency of the principle. The aim is to secure the firmness of leadership in politics. This firmness will produce the cognitive element. Secondly, the same letters insist upon the necessity of "identifying with" and "inclining towards" the spirit of people as such. This assertion means that we ought to know the indefinite "elements" in politics as indefinite. 